\title{
DE SINGAPOORSCHE PAPIEROORLOG
}

\author{
DOOR
}

\author{
P. H. VAN DER KEMP.
}

If you can be sound.

Canning dd. 26 Juli 1820 aan Fagel en Elout.

De heer Jules Le Clereq, die eenigen tijd geleden waardeerende artikelen in Fransche tijdschriften over Java schreef, en met wieu ik het genoegen had kennis te Brussel te maken, had de vriendelijkheid mijne aandacht te vestigen op eene advertentie over "The life of Sir Stamford Raffles" door Demetrius Charles Boulger, Londen 1897. Het gaf mij aanleiding dit werk te lezen.

Het boek maakt op de vele Engelsche schrifturen, die over onze koloniën handelen, geene uitzondering, wat betreft de onderschatting van het Nederlandsch beheer. Doorslaande en scheldende, worden domheid en eenzijdigheid gekleed in den toon der aanmatiging. Trouwens wanneer men van de Nederlandsche taal niet anders schijnt te verstaan dan het schamper gebruikte Mijnheer, kan men bezwaarlijk een werk samenstellen, hetwelk de geschiedenis onzer koloniën raakt, zonder aan de eischen van ernstige studie, wetenschap en critiek tekort te doen. Het is niet zoozeer de partijdigheid, die in dergelijke jingo-werken hindert. Waar de geschiedschrijver niet met zijn onderwerp kan leven, geen gevoel toont te hebben voor de lotgevallen zijner helden; voor het land, waarvan het verleden geteekend wordt; voor het volk in zijne grootheid of achteruitgang: daar weet hij geen geest, geen talent, geen leven in de teekening te leggen; doch het moet eene partijdigheid zijn, voortgevloeid uit ernstige studie van de stukken der wederzijdsche partijen, zooals ook eerst de rechter zijn oordeel vormt. "La seule impartialité qu'on puisse lui demander", merkt zoo juist G. Valbert op in zijne beschouwingen over den 6e Volgr. V. 
geschiedschrijver Von Treitschke (Revue des Deux Moniles, 1 Februari 1898 bl. 692), "est cette équité exacte et scrupuleuse qui ne condamne aucun ennemi sans l'avoir entendu, qui ne prononce aucune sentence définitive sans avoir donné la parole à l'accusé et écouté patiemment ses raisons, examiné avec soin ses pièces justiticatives."

Over het geheel genomen staat in dit opzicht de Nederlandsche geschiedschrijver zéér hoog; de jingo-schrijver dikwerf bedroevend laag. Boulger's boek maakt daarop geene uitzondering. Van het Bandjermasin-schandaal natuurlijk geen woord! Van Raffles' bloedbrieven naar Palembang leest men enkel (bl. 90): "He entered into an unsatisfactory negotiation with the cruel Sultan of Palembang." Och kom! En eenige bladzijden verder: "For some reason that cannot be confilently explained, the Sultan adopted a hostile course, massacred the Dutch settlers, attempted to deal out the same treatment to the English officers, and openly defied the British power" (bl. 1 1 0). Van majoor Mulder's heldendood in 1811 bij de verovering van Meester-Cornelis door de Engelschen wordt gezegd (bl. 130): "two gallant French officers... fired the magazine", waarna "the Franco-Dutch army" op de vlucht ging. Van onzen 80 -jarigen oorlog wordt medegedeeld (bl. 292), dat in de $16^{\text {e }}$ eeuw de Nederlanders "did something for the cause of liberty in Europe", en dan nog slechts dat something: "aided by subsidies and other support from England". Zelfs waar de Schrijver geheel op de hoogte kon zijn, waar hij zich toch op zijn eigen terrein bevindt, oordeelt hij het beter een opgesmukt verhaal, in de Memoir van Raffles' weduwe voorkomende, na te schrijven, dan het vertrek van zijn held uit Java in het juiste licht te stellen. Op bl. 211 wordt namelijk beschreven de overgave van Java en onderhoorigheden door Raffles aan Fendall, zoomede Fendall's overgave ervan aan Commissarissen-Generaal "with the exception of Banca and Banjermasin", terwijl de Schrijver zeker in plaats van Banka bedoelt Billiton; en dan laat hij volgen: "At first Raffles had intended to proceed direct to Bencoolen; but the state of his health was such that the doctors gave him imperative orders to return to Europe as the only means of saving his life." Met slechte of goede gezondheid, Raffles werd verboden naar Benkoelen te gaan, indien hij zich niet eerst yan de tegen hem ingebrachte beschuldigingen had weten te zuiveren. In zijn eigen Statement verhaalt bij het nota bene zelf; men zie bl. 348 mijner verhandeling 
over "Fendall's en Raffles' opvattingen", bl. 8 overdruk. - De gansche bladzijde 293 van Boulger is geschetter tegen ons koloniaal beleid, met den moord van Amboina in 1624 natuurlijk bovenaan! Ter zijde stellende het feit, dat in die tijden de Éngelschen even exclusief waren als de Nederlanders en andere Europeesche natiën, wordt deze politiek als een kenmerkende karaktertrek onzer natie op den kaak gesteld tot zelfs... in de Transvaal! "What was true in Japan and Java in the seventeenth century, and throughout the Eastern Archipelago during the eighteenth century, has been not less evident in the Transvaal." En die jingo-onzin bereikt het toppunt aan het slot van het werk (bl. 391), waar verzekerd wordt, met "high authority", dat toen er tijdens den laatsten FranschDuitschen oorlog voor Nederland gevaar bleek te bestaan om door Duitschland te worden ingepalmd, "the Governor of the Dutch East-Indies declared that as soon as the Black Eagle was hoisted at the Hague, he would run up the Union Jack at Batavia"!! Al dat moois heeft Engeland overigens te danken aan den held van het werk, aan Sir Stamford Raffles.

De geschiedenis zou het, als het er toe kwam, wel anders leeren. Indien vaderlandsliefde en plichtgevoel niet genoegzaam waren, om ook bij onthouding van voldoende verdedigingsmiddelen, tot het laatst zich tegen een nieuwen Engelsehen inval op Java en elders te verdedigen, dan zoude het zijn de herinnering aan Engelsche laatdunkendheid, die, gelijk ons nog dezer dagen herinnerd werd door kolonel W. C. Nieuwenhuyzen in zijn voortreffelijk, vaderlandschlievend artikel over "Poeloe Weh" in De Indische Gids van April 1898, met al hare theoriën over vrije toelating, de vrijheid alléén voor zich zelven, ten koste van andere nationaliteiten, reclameert. Dat hebben wij ondervonden in Britsch-Indië, dat hebben wij gevoeld aan De Kaap en dat is de geschiedenis der Nederlandsche republieken in Zuid-Afrika.

Doch al is Boulger's werk een onsympathiek en tot zekere mate onwetenschappelijk boek, daarom is het toch geenszins onbeteekenend. De Schrijver geeft onderscheidene officieele stukken weder, die op onze geschiedenis een nieuw, of laat ik liever zeggen, een helderder licht werpen. Niets verplicht ons zijn onredelijken gedachtengang te volgen; wij kunnen dien ter zijde laten en gebruiken, wat inderdaad juist en waar is.

Daaronder behoort de uiteenzetting betrekkelijk "The founding of Singapore", niet natuurlijk weder wat betreft Engelands recht 
tot handelen - dat is een jingo-thema - doch wat medegedeeld wordt ten aanzien van ons optreden om het gepleegde feit ongedaan te maken. Vòò ik met het werk kennis had gemaakt, was door mij deze verhandeling voltooid onder den titel van "De Uriefwisseling van Februari 1819 tot April 1820 tusschen de landroogden van Nederlandsch- en Britsch-Indie over de stichting van Singapore"; en uit de stukken, die mij toen onder de oogen waren gekomen, had ik mijne opmerkingen ter neder geschreven over de janmerlijke opvatting onzer Regeering, die niets anders heeft weten te doen dan protesteeren en brieven schrijven. Teneenenmale onjuist is het dus wanneer "Bintang Djaoeh" in Eigen IIaard van 1 en 8 Januari 1898 over "Benkoelen voorheen en thans" schrijvende, ten aanzien der stichting van Singapore op bl. 22 aanteekent: De Nederlanders "merkten het nauwelijks op en protesteerden niet, en toen ze het eenmaal begrepen, was het te laat". Wij hebben, nota bene! niets anders gedaan dan protesteeren van het eerste oogenblik tot 1824, toe ! ' - Boulger schrijft bl. 319: "No one has ever realised, or perhaps known, how nearly the occupation of Singapore fell through or ran the risk of early repudiation"; nochtans had ik dien indruk zelfstandig uit de bestudeering der schrifturen gekregen; alleen doet de Schrijver mij nu meer helder en overtuigender zien, welk een geheel ander resultaat wij zouden gehad hebben, indien de Indische regeering kloek ware opgetreden of indien Muntinghe, na te Palembang de Salmond-daad te hebben volbracht, te Malakka als commissaris ware geweest. Deze bevestiging van eene door mij reeds gevorınde meening deed mij het ten einde gebrachte opstel geheel omwerken tot den vorm, waarin ik het nu onder een anderen titel aanbied.

Onder de belangrijke officieele bescheiden, die Boulger in zijn werk heeft opgenomen - ik zal er met de letters $B g$ naar verwijzen - noem ik de instructiën dd. 28 November en 5 December 1818 door den Gouverneur-Generaal van Bengalen, lord Moira, markies van Hastings, aan Raffles verstrekt, voor het zoeken naar eene Engelsche vestiging in de omstreken van Malakka. "As", zegt de Schrijver bl. 298, "the precise nature of the Instructions given to Raffles by Lord Hastings are most important, and have never been published, I give the full text of the official documents preserved in the Political Department of the India Office." Ik wilde hiertegen opmerken, dat dan toch onze Van Deventer 
op bl. 295 vv. van zijn Opkomst (verkort aan te halen $V$. D.) die stukken reeds in 1891 had geopenbaard, dech nu bemerk ik uit de vergelijking der beide publicatiën hoe knoeierig alweder deze Nederlandsche geschiedschrijver het gedaan heeft. In de eerste instructie liet hij toch, waar de stippels bij hem staan, een meest gewichtig deel weg, hetwelk bij Boulger ruim ééne bladzijde, compres gedrukt, inneemt; en ofschoon bij de tweede instructie geene weglatingen worden aangeduid, blijkt me nu, dat ook daarvan het grootste gedeelte niet werd overgenomen! Met andere woorden, voor eene zelfstandige studie, en juist daarvoor dient de openbaarmaking van bescheiden, heeft men aan V. D.'s mededeeling niet genoeg.

Breede aanhalingen zal ik mij veroorlooven uit het "Verhaal wegens het gepasseerde bij het Commandement over het esquader in de Oost-Indiën gerlurende den jare 1\$18" van den schout-bij-nacht C. J. Wolterbeek, uit de Wolterbeek-verzameling op 's Rijks archief, waarvan ik bereids gewag maakte sub 64 mijner jongste verhandeling over Sumatra's Westkust in deze Bijdragen (dl. XLIX bl. $269 ; o v .65$ ). Wolterbeek heeft de gebeurtenissen medegemaakt en ze onder den indruk van het oogenblik gejournaliseerd. Daardoor krijgt de stijl dikwerf iets teekenends, dien men door nadere omschrijving slechts kan bederven. Ik zal het boek verkort aangeven als Journaal of Verbaal. In 1872 werd de verzameling door een bloedverwant, den heer Muller, aan het Archief ten geschenke gegeven.

Levensbijzonderherlen ran Johan Constantijn Wolterbeek, Vice-Admiraal werden door D. G. Muller gepubliceerd op bl. 269 vv. der "Verhandelingen en berichten betrekkelijk het Zeewezen enz." van Tindal en Swart $6^{\text {e }}$ dl. $2^{\text {e }}$ st. 1846. Gelijk ik op bl. 415 vv. zal mededeelen, komt daarin eene bijzonderheid voor, die ik liever anders zou hebben gelezen.

Herhaaldelijk wordt door mij verwezen naar E. Netscher: "De Nederlanders in Djohor en Siak" (1870), gepubliceerd door de Verhandelingen van het Bataviaasch Genootschap van Kunsten en Wetenschappen, in een onbehagelijk formaat. Verkort Netscher.

Onderscheidene brieven uit Bisschop's verzameling zullen in de bijlagen dezer verhandeling mede verschijnen. Verkort $B$ Op sommige stukken vestig ik de aandacht, dat zij niet in het Engelsch overgenomen hadden behoeven te worden, wijl onze archieven ze bevatten in de taal, waarin ze zijn geschreven: het Fransch. In 
zijn "Unilerzoek van stukken in het India Office" (dl. XLVII dezer Bijdragen 1897) maakt trouwens Mr. Bisschop hiervan zelf melding (bl. 190 en 291).

De "Bijolragen tol de geschiedenis der onderhandelingen met Engeland, enz." door den heer Elout van Soeterwoude in 1863 bezorgd, waarin vele stukken van den oud-commissaris-generaal en oudminister Elout, zal ik aanhalen met de woorden Bijdragen $E$.

Naar mijne verhandeling over "Feulull's en Raffles' opvattingen" in deze Bijdragen, dl. XLVII (1997), bl. 34l vv. verwijs ik onder Opvattingen.

$\mathrm{Nu}$ en dan breng ik de gebeurtenissen van Palembang ouder den commissaris Muntinghe in herinnering. Hierover verscheen van mij een artikel in De Gicls van Februari 1898, bl. 253 vv. Men zal daaruit kunnen zien o. a , dat Salmond en de zijnen met eene Arabische brik naar Batavia de reis makten en dus niet op een Nederlandsch oorlogsschip, zooals Boulger op bl. 275 vertelt, hetgeen voor de kennis van het karakter dezer opzending geenszins van belang ontbloot is. Ook logeerde Salmond 8 dagen lang bij ons bestuurshoofd te Muntok, terwijl het schip daar verblijven moest om het in orde te maken.

In de Nieuwe Rollerlammer van 11 Februari 1898 kwam over de verhandeling het volgende voor: "Gelijk onze lezers in een andere rubriek van dit blad hebben gezien, leidt de heer P. H. van der Kemp in De Gids een opstel over Een Engelsche raid op Hollanisch grondgebied in met een herinnering aan Jameson's tocht. De Schrijver makki het daarin de bedrijvers van dien aanslag op Transvaal tot een verwijt, dat zij 'niet van een strooptocht, maar slechts van een raid' wenschten te spreken. Nu duiden wij Jameson en zijn handlangers hun inval ten kwade genoeg, maar het lijkt ons wat streng van hen te eischen, dat zij hun raid op zijn Hollandsch rooflocht moeten noemen. Evenals de Poet Laureate Austin van een ride te spreken, ware af te keuren, maar als zij hun rooftocht een raid noemen, dan blijken zij ten minste den moed te hebben, to call a spade a spade." - Ik ben er heusch niet van bewust deze onderwijzing te verdienen. Ik makte niemand een verwijt, doch herinnerde slechts aan een feit, dat ter terechtzitting had plaats gevonden, toen Jameson verzocht het woord roof- of strooptocht niet te gebruiken (ik herinner mij niet meer het gebruikte Engelsche woord), doch liever van een raid te spreken. En deze herinnering had geen ander doel, dan enkel om 
te verklaren, hoe ik aan den titel mijner verhandeling kwam, juist wijl het woord door mij zoo goed gekozen werd geacht!

In mijne door deze Bijilragen opgenomen voorgaande verhandeling over "Sumatri's Westkust naar aanleilling van het Lonilensch tractaat van !3 Augustus 14l4" (bl. $205 \mathrm{vv}$.) heb ik eenige malen verwezen naar het te publiceeren artikel over "De briefwisseling van Februari 1819 tot April 1820 tusschen de landvoogden van Nederlandschen Britsch-Indië over de stichting vau Singapore". Gelijk ik hiervoren op bl. 392 mededeelde is nu deze titel veranderd; doch bovendien versprongen de aanteekeningen, waarnaar ik in de verhandeling over Sumatra's Westkust verwees. Zoo bedoel ik met sub 26 en sub 29 , vermeld in de noot op bl. 268 ( ov 64) dier verhandeling, de brieven sub 50 en sub 53 hierachter afgedrukt.

Het nu gepubliceerde opstel was reeds afgesloten, toen ik kennis kreeg van De Economist, Maart 1898, waarin weder voorkomt eene zoo zeer door een ieder hoog gewaardeerde rubriek "Koloniale Literatuur" van Mr. J. K. W. Quarles van Ufford. Over mijne historische bijdragen sprekende, maakt Mr. Quarles de volgende opmerking "Hij geeft zijn vele Toelichtende aanteckeningen achter zijne stukken eu niet onder de bladzijden en dwingt dus zijn lezer, die onder het lezen tevens van de aanteekeningen wil kennis nemen, deze achter het stuk op te zoeken. Wij gelooven dat verreweg de meeste ernstige lezers, en anderen zullen de stukken van den heer van der Kemp wel niet ter hand nemen, het met ons aangenamer zouden vinden de noten aan den voet der bladzijden dan achter het stuk te vinden. Wij zouden daarom den geachten schrijver wel in overweging willen geven de noten onder de bladzijden te plaatsen, alleen enkele meer uitgebreide van de toelichtende aanteekeningen of bijlagen aan het slot van het stuk gevende."

Ik ben tot deze manier gekomen, doordien zij mij persoonlijk bij andere schrijvers, waar ik ze aantrof, het beste beviel; o. a. bij Mr. Mijer in zijn zoo schoon gestileerd werk over J. C. Baud. Hoe meer noten aan den voet van de bladzijden, hoe onaangenamer de lectuur; telkens wordt de lezing afgebroken, aanhoudend de gerlachte afgeleid door het kennisnemen van tusschengevoegde opteekeningen, waarvan men het oog niet kan afhouden en die toch dikwerf de moeite der lezing niet waard blijken, gelijk verwijzingen naar andere werken; ophelderingen om mogelijke bezwaren, die echter bij den lezer niet rïzen, weg te nemen; verbeteringen van hetgeen elders minder juist wordt geacht; enz. enz. Toen ik 
eens met iemand de waarde van historische studiën besprak, voegde hij mij toe: "och, dat is eigenlijk allemaal nieuwsgierigheid, waaraan men feitelijk al heel weinig heeft". Eene charge natuurlijk, doch met dezelfde overdrijving zou ik hier wagen te zeggen: dat lezen van de noten bevredigt noch loont de nieuwsgierigheid. Waar zij voor het goed begrip der verhandeling inderdaad onınisbaar blijken, wordt er de arbeid van den schrijver zelf, in zoover mede veroordeeld, dat liij dan in zijn artikel niet de vereischte volledigheid heeft betracht.

De door den heer Quarles aangegeven onderscheiding van ernstige en niet-ernstige lezers van mijne verhandelingen zou ik liever niet in dit opzicht wenschen te aanvaarden; ik meen het er voor te mogen houden, dat vele "ernstige" lezers de kennisneming der noten volstrekt niet behoeven. Doch iets anders is het, waar er zijn, die zich aan zelfstandige studie en critiek wenschen te wijden; zij behooren niet alleen de bronnen te weten, waaruit men heeft geput, doch ook die bronnen zelven, zoo mogelijk met besparing vau moeitevol en tijdroovend archievenonderzoek, te kunnen lezen, en wel niet zoo zeer, omdat men des schrijvers eerlijkheid niet vertrouwt, als wel omdat verschillende menschen in hetzelfde zeer dikwerf verschillend lezen. Zoo heb ik uit de raadpleging der archiefstukken over de geschiedenis van Commissarissen-Generaal in menig opzicht een gansch anderen indruk gekregen, dan de velen, die vóór mij hetzelfde tijdvak behandelden. Voor dergelijke studie nu, hindert het m. i. al zeer weinig, waar de noten geplaatst zijn.

De door den heer Quarles aangewezen weg, om slechts de meer uitgebreide aanteekeningen aan het slot van het stuk te geven, maakt mijn bezwaar tegen het stellen onder de bladzijden uit den aard der zaak nog grooter; want dan komen er bovendien noten, met de enkele verwijzing: zie bijlage zooveel.

Intusschen den hooggewaardeerden kroniekschrijver zeg ik het na: variis modis bene fit; mijn oordeel geef ik gaarne voor beter. In eene volgende verhandeling zal ik nader het volgen van den aangewezen weg overwegen. Ik kan er alleen nog aan toevoegen, dat voor den schrijver zelf mijne wijze van behandeling veel lastiger is dan de door den heer Quarles bedoelde, omdat de volgorde der noten, de verwijzing naar de nommers, enz. menigmaal nog onder de behandeling verspringen, zoodat men zich dan verplicht ziet, de geheele verzameling noten met de verwijzingen onder andere cijfers te brengen. 
I.

Commissarissen-Generaal deden een kostbaren tijd aan velerlei quaestiën van betrekkelijk ondergeschikt belang voorbijgaan. Elout's advocatery tegenover Fendall in Rade had bovendien geenszins de vruchten gedragen, evenredig aan de krachten, die er mede waren verspild. Terwijl Sumatra's Westkust en Malakka op de Nederlandsche vlag wachtten, verschreven wij gedeeltelijk nutteloos de dagen met de overgave eerst van Java, daarna van Bandjermasin. Het resultaat was, dat Fendall, persoonlijk verstoord over ons optreden, Java verliet met ernstige grieven tegen de behandeling van zaken door Commissarissen-Generaal, en aldus ontvankelijker werd voor de stappen van toenadering, die Raffles als luitenant-gouverneur van Benkoelen noodig en nuttig achtte te Calcutta te doen. ${ }^{2}$

Een paar jaar te voren toch had Raffles te vergeefs verzocht naar Bengalen te mogen komen om zich op Gillespey's beschuldigingen mondeling te kunnen verantwoorden; lord Moira, hem toen niet willende ontvangen, verwees hem naar de autoriteiten in Engeland, waarheen hij dan ook, na zijne vervanging te Batavia door Fendall, was gegaan. Te Londen wist hij zich schoon te wasschen van hetgeen men tegen hem ingebracht had; en dientengevolge keerde hij als luitenant-gouverneur naar den Archipel terug, doch als bestuurder van het onbeduidende Benkoelen, den reeds door lord Moira's voorganger hem toegezegden post ${ }^{3}$. Zijne intriges van daar in de Lampongs en Palembang, zijne weigering tot overgave aan ons van Padang, de openbaarmaking van het tegen C. C. G. G. gericht protest hadden niets dan afkeuringen bij het Britsch-Indisch bestuur ten gevolge; en uit dien hoofde achtte hij het weder noodig naar Calcutta te gaan, ten einde lord Moira mondeling te kunnen waarschuwen tegen het drijven der Nederlanders tot hetgeen hij noemde uitsluiting, monopolie, doch hetgeen niets anders was dan hetgeen ieder ondernemend bestuur zou doen, namelijk de vlag planten, waar dit noodig mocht blijken. Met een hartelijk antwoord van lord Moira werd hij nu welkom geheeten *. Boulger gelooft dat Fendall op dien omkeer invloed heeft uitgeoefend ${ }^{5}$; zeker is dat de Landvoogd een bijzonder ongunstigen indruk over Elout's optreden had gekregen.

In October 1818 zeilde Raffles naar Calcutta; hij had er groot succes. Waren er door C.C.G.G. bij den Britschen landvoogd 
klachten ingediend, dat de luitenant-gouverneur van Benkoelen zich den titel van agent in de Oostersche zeeën aaumatigde, nu ontving hij van het bestuur eene machtiging, die geheel met dien titel overeenkwam, en wel speciaal de opdracht om zich in den Riouwarchipel te vestigen. Het stuk was van den $28^{\text {n }}$ November 1818 ; dd. 5 December volgde een nader schrijven, inhoudende dat zoo Riouw reeds door de Nederlanders bezet mocht zijn, hij met den sultan van Djohor op Malakka moest trachten een verbintenis voor het openen van een Engelsch etablissement aan te gaan. De Landvoogd, geheel verkeerd ingelicht door den onbetrouwbaren LuitenantGouverneur, wist niet, dat de Riouw-archipel eene onderhoorigheid van Djohor was en de sultan van het rijk op de eilanden zijne residentie hield.

Toen eerlang lord Moira begreep dat men hem misleid had, toonde hij zich op Raffles ten hoogste vertoornd, en het zoude daarbij niet gebleven zijn, indien wij slechts van onze zijde dezelfde mannelijke voortvarendheid hadden getoond als te Palembang. Bij zwakke heerschers, als inderdaad lord Moira was, wordt ten slotte veel door het succes goedgemaakt; en dit werd door onze ongelukkige houding verzekerd. Het spreekt vanzelf, dat Boulger over den ongunstigen indruk, dien Raffles' daad te Singapore op lord Moira's rechtvaardigheidsgevoel maakte, niet goed is te spreken. Idealen van eerlijkheid, goeden trouw, worden door deze menschen in historische nauwgezetheid met voeten getreden. Het cave canem zij daartegen het eenige wachtwoord.

Een advocaat als Mr. Elout kende voldoende het beatu possessio; hij schrijft er met zoovele woorden dd. 5 December 1820 over (Bijdr. E. bl. 161); maar waarom dan ook niet eerst zich gehaast met te benaderen, wat het tractaat van 1814 ons teruggaf? Waarom getalmd met een Bandjermasin, gelijk ik verhaalde; waarom met Padang; waarom, als middelen tekort schoten, in Palembang niet eene getemperd vredelievende politiek gevoerd in plaats van daar alles tegen ons in het harnas te jagen? Waarom dientengevolge eerst ter elfder ure Malakka teruggenomen?

Gewichtig hiervan toch bleken de gevolgen; want nu waren wij daar ter nauwernood gevestigd en hadden wij nog geen tijd kunnen vinden oude betrekkingen in voldoende mate te hernieuwen, grondige kennis op te doen van toestanden en verhoudingen, of Raffles vond eene gunstige gelegenheid er mede de schendende hand in te slaan. Voor mij bestaat geen twijfel, dat 
het Palembangsche zelfvertrouwen met eenerlei succes te Singapore zou bekroond zijn geworden; toen reeds echter was de geestkracht, die tot deze schoone daad leidde, er uit; 't was wel gauw! Wij vleiden ons met kalm geschrijf het evenzeer te kunnen winnen, waar het op den keper beschouwd, slechts gold politiegezag uit te oefenen, al ware het dan ook hooge politie. De papiermachine was bereids door Elout zoo hoog opgevoerd, dat de vreemdeling om al dat gepleit lachte. Het zij zoo; indien het maar uiet verhinderde te toonen, dat men ook het woord bij de daad kon voegen; maar anders wordt het eene armelijke vertooning, waarvan men zich met een gevoel van weerzien afwendt. "Mynher will propably enter into a paper war on the subject", schreef Raftles na de stichting van Singapore aan C. Assey, toen in Engeland (Bg. 310); en het werd inderdaad een papieroorlog!

II.

"In aanmerking genomen zijnde, dat vermits alsnu de benoodigde middelen aanhanden zijn om het gouvernement van Malakka over te nemen, uit handen der Britsche autoriteiten aldaar, en dat het noodzakelijk is zonder verwijl eene commissie derwaarts te zenden, ten einde de zaken betrekkelijk die overname te regelen en in het bestier te voorzien", - benoemde onze Regeering bij besluit dd. 7 Juli $1818 \mathrm{n}^{\circ} 30$ tot commissarissen voor de overneming de heeren J. C. Wolterbeek en J. S. Timmerman Thijssen. - Dat "zonder verwijl" is even eigenaardig als de "korte, doch krachtige" brief, die, blijkens sub 45 mijner verhandeling over Sumatra's Westkust dd. 30 Juni 1818 , Elout c. s. hadden doen afgaan tegen de weigering tot het overgeven van Padang.

Wolterbeek was als schout-bij-nacht commandant van het naar Malakka te stevenen eskader. Dit had tevens ten doel om de zeerooverij in straat Banka enz. te bestrijden, zoomede commissaris Muntinghe te Palembang, indien noodig, bij te staan. Verder behoorde tot Wolterbeek's eskader eene divisie, bestemd om onder den kapitein ter zee Stout naar Borneo te stevenen, ten einde commissaris Van Boekholz, die in Bandjermasin ons gezag had hersteld, naar Borneo's Westkust te begeleiden, en nu met name ons gezag behoorde te vestigen te Sambas en Pontianak. Stout had daar troepen en eenige schepen te laten en vervolgens naar Malakka te gaan, ten einde zich bij de schepen van Wolterbeek te voegen. 
Al deze bewegingen waren het gevolg van Raffles' streven om zich mede vestigingen in den Oost-Indischen archipel te verzekeren.

Nadat de expeditie-Stout reeds den $2^{\text {n }}$ Juli 1818 Batavia had verlaten voor Borneo's Westkust, zeilde Wolterbeek een week later, den ] $8^{\mathrm{n}}$, uit. Voor de rivier van Palembang komende, vernam hij de gevangenneming der expeditie-Salmond, de opzending "met de meeste discretie" naar Batavia en verder den betrekkelijken staat van rust te Palembang. Dientengevolge zette Wolterbeek de reis naar Malakka eenvoudig voort, echter niet zonder een duister gevoel, dat eerlang zijue schepen wel op Sumatra's Oostkust noodig zouden zijn. Den $21^{\mathrm{n}}$ Augustus kwam men op de reede ter plaatse van bestemming. Het schip, dat Commissarissen overvoerde, was het oorlogsfregat Tromp, doch het werd tevens o. a. vergezeld door de Wilhelmina, hetzelfde oorlogsvaartuig, dat eene vergeefsche reis met den commandant Dibbetz en commissaris Du Puy naar Benkoelen had gemaakt, en juist terugkwam, toen men zich met de expeditie naar Malakka onledig hield. Wolterbeek was alzoo ten volle van het over Padang gebeurde op de hoogte; hij wilde voorkomen, dat hetzelfde te Malakka zou gebeuren en daarom haastte hij zich om reeds den $22^{\mathrm{n}}$ de ontscheping van een deel der troepen, artillerie enz. te doen geschieden, ofschoon voor logies en berging natuurlijk geene geschikte gelegenheid bestond. Het kwam hem daarbij wellicht ten goede, dat de resident Farquhar zich niet ter plaatse bevond, en het bestuur dientengevolge door een ondergeschikte, den heer Kenneth Murchison, werd waargenomen. Wèl was door het Pinangsch bestuur gelast, dat de landing der troepen geene vertraging door Farquhar's afwezigheid moest ondervinden ${ }^{6}$, doch Farquhar zelf zou wellicht eigenmachtig op het vernemen der Palembangsche geschiedenis de ontscheping der troepen geweigerd hebben.

Het doel van Farquhar's reis was geene andere dan dat door Raffles beoogd op de reis naar de Pasoemah, toen Du Puy te Benkoelen aankwam en op de reis naar Menangkabau, toen Heemskerk andermaal derwaarts werd gezonden, namelijk ons den voet dwars te zetten. De gouverneur van Pinang, kolonel Bannerman en zijn raad hadden toch Farquhar aangewezen de Engelsche belangen te behartigen op Borneo, te Riouw en in Siak, gelijk Mr. Bisschop op bl. 199 van zijn Onderzoek herinnert, "for fear that the Dutch might re-establish their monopoly of formes years", berichtte het bestuur bij brief dd. 17 October 1818 naar Calcutta. De expeditieStout kwam echter den resident van Malakka voor. Toen de En- 
gelsche missie op Borneo's Westkust belandde, had Van Boekholz reeds het Nederlandsch gezag er doen aannemen en dientengevolge Farquhar op weinig vriendelijke wijze medegedeeld, dat hij er niets te maken meer had, hetgeen, naar ik in de Bundjermasinverhandeling aanteekende ${ }^{7}$, tot eene correspondentie tusschen Calcutta en Batavia aanleiding gaf. De Resident deed op de terugreis den Riouw-archipel aan en daar slaagde hij beter; immers den $19^{\text {n }}$ Augustus 1818 wist hij met den sultan van Riouw, Djohor enz. een contract te sluiten, waarin aan Engeland eene gunstige handelspositie werd toegezegd ${ }^{8}$.

Intusschen zaten onze Commissarissen op 's Residents terugkeer te wachten, aangezien Murchison verboden was geworden eenige onderhandeling betrekkelijk de overneming te openen. Wolterbeek liet niet na daarover groote ontevredenheid te kennen te geven, doch juist was door Commissarissen een brief van ergernis aan den gouverneur te Poeloe Pinang, waaronder Malakka ressorteerde, geschreven, toen nog vóór daarop antwoord was gekomen, den $1^{\mathrm{n}}$ September Farquhar te Malakka voet aan wal zette. ${ }^{9}$ Het beleidvol optreden van den Schout-bij-Nacht verschijnt hier in een helder licht; zonder zijne haastige ontscheping, zonder ook zijn hoogen aandrang om de overneming te beëindigen, dreigde de zaak naar hetzelfde beloop als te Benkoelen met Padang had plaats gevonden. Onder de geruchten toch van de Palembangsche gebeurtenissen zocht de Resident, evenals Raffles het had gedaan, naar allerlei beweegredenen tot het rekken der besprekingen; ook kwam men er met de rekening der bewaarneming voor den dag. - Eindelijk was men den $21^{\mathrm{n}}$ September zóó ver gevorderd, dat toen de overneming plaats vond, ofschoon nog tal van quaestiën ter behandeling overbleven, waarmede de gansche maand October verliep, hetgeen vermoedelijk Mr. Hoek op blz. 147 van zijn "Herstel" en Spengler op bl. 93 zijner dissertatie over Van der Cappellen ten onrechte deden schrijven, dat de overneming tegen het einde van October plaats vond.

Ofschoon Farquhar gaarne zich de eer van een Raffles' rol wilde zien toegekend, bezat hij er noch de talenten, noch de loosheid, noch het doorzicht voor. Men zal het dikwerf zien, dat bij naamgevende ontdekkingen enz. menschen van mindere bekwaamheden op den voorrang aanspraak maken, die aan anderen met recht stilzwijgend reeds werd toegekend. Deze mindere grootheden hebben dan precies hetzelfde, of nagenoeg precies hetzelfde 
gezegd of gewild; doch waar ze gelegenheid tot handelen of spreken vonden, toonen zij zich in gedachtengang, opvatting, leiding zoo volstrekt de minderen, dat men zich over de naïveteit te verwonderen heeft, waarmede zij hunne aanspraken voorop zetten. Wat wij hier zien, is werkelijk typisch. Gelijk roovers het over de verdeeling van den buit steeds oneenig worden, zoo ook kreeg Raffles met zijn handlanger de hoogste onaangenaamheden over de eer van beider werk te Singapore. Wij kunnen deze belangwekkende quaestiën bij Boulger op bl. 351 vv. lezen; maar reeds met betrekking tot Riouw beging Farquhar eene dubbele fout, waaraan zich Raffles zeker nooit zou hebben schuldig gemaakt.

Naar ik mededeelde, was door den Resident met den sultan van Riouw een contract gesloten, zonder er evenwel de Engelsche vlag te hijschen, zonder er eene bezetting, hoe gering ook, te laten. "By neglecting to occupy the place, we lost Rhio", schreef Raffles gansch teleurgesteld dd. 16 Januari 1819 aan Marsden (Memoir bl. 374). Had Farquhar er nu maar verder bij onze Commissarissen over gezwegen of althans het contract voor zich gehouden; doch hij schijnt onder den indruk te zijn geweest, dat het genoeg was dergelijke papieren te laten zien om ons af te schrikken op hetzelfde terrein te gaan vagebondeeren. Misschien ware dit doel ook wel bereikt bij eene zwakkere persoonlijkheid dan Wolterbeek; nu zou zich echter de Resident geheel misrekenen. Aardig is de gansche toedracht in het Journaal ons medegedeeld. Ziehier den nuchteren aanloop ad September 1818: "Den $15^{\mathrm{n}}$ ontvangen van den heer Farquhar ter lecture de contracten door hem op zijne laatst afgeloopen reis met de vorsten van Siak, Perak, Riouw en Linga gesloten; - vertoonende dit eene attentie voor ons commissarissen, teffens om in onze handelingen met die vorsten daaromtrent onderricht te zijn. Lieten dezelven ter onzer informatie copieeren."

Bij copieeren bleef het echter niet. Farquhar kon over zijn triomf den mond niet houden, zoodat op zekeren dag, nadat de overneming van Malakka reeds plaats gevonden had, "eene interessante conversatie" voorviel, "omtrent het sujet van de intentie bij het Engelsch Oost-Indisch gouvernement, of wel de voordracht daartoe aan het Suprême Gouvernement, om na de overgave van Malakka zich elders oostelijker te vestigen"! Wolterbeek had dit plan "zoo onmogelijk als onbestaanbaar" bestreden, "wiji de vorsten van Djohor, Riouw en Pahang met hun gansche rijk, eilanden als anderszins, 
leenroerig aan het Nederlandsch gouvernement moesten worden beschouwd en dus niets zonder onze voorkennis konden afgeven". Farquhar wilde zich tegen deze opvatting "met alle kracht" verzetten, "doch in raisonnement te kort komende", rergat hij zich zoo ver, zegt de verontwaardige zeeman, dat Farquhar uitriep: "In alle gevallen zijn uwe contracten met de Oost-Indische Compagnie gesloten, en die bestaat nu niet meer." Onze Commissaris "retireerde" hierop, na ten antwoord te hebben gegeven: "Als U zoo begint, dan breek ik alle discoursen met $U$ af en zal mij dus verder excuseeren."

Om de waarde van dezen woordentwist wel te vatten, zij herinnerd, dat tot het voormalige Djohorsche rijk behoorden al de eilanden, welke thans tot het gebied van het rijk van Linga en Riouw behooren, benevens het Maleische schiereiland, waarop Djohor ligt, met uitzondering van het op de westkust gelegen gebied van Malakka; eu verder dat den $1^{\mathrm{n}}$ November 1784 , een contract van suzereiniteit tusschen onze Compagnie en den Sultan was gesloten, - bij Netscher bl. 197 afgedrukt — zoodat met de teruggave van het schiereiland Malakka, den geheele Riouw-archipel, naar opvatting van Wolterbeek, weer medeging.

Farquhar wenschte het echter niet bij het in oneenigheid afgebroken gesprek te laten, doch verklaarde zich nader schriftelijk in een brief dd. 22 October $1818^{10}$. "In deze missive", teekende de journalist op, "wilde ZHEdG. ons beduiden, tot voorkoming van allen misverstand, dat de toestemming, van den vorst van Riouw werkelijk gegeven was, om zich op een of ander oord te kunnen nederzetten in zijne staten, en daarom als onafhankelijk van ons beschouwd, de voordracht aan het Suprême Gouvernement gedaan was." - Onze Commissarissen wederlegden de argumenten bij een brief aan Farquhar dd. 31 d.a. v. ${ }^{11}$; Wolterbeek had intusschen meer gedaan dan dezen "papieroorlog" te voeren. Achtereenvolgens waren door hem met onbekenden koers zonder ophef de schepen van Malakka naar Riouw gezonden, goed voorzien van manschappen enz.; en hijzelf ging, zoodra de afsluiting der zaken met den Engelschen resident het toeliet, 's avonds den $3^{\text {n }}$ November 1818 mede derwaarts, "profiteerende alstoen van een lief landwindje", zegt het aantrekkelijk dagboek. Farquhar wist van niets! De bijzonderheden van hetgeen verder gebeurde, kan ik echter hier niet mededeelen, wijl het mij te ver buiten het onderwerp dezer verhandeling zou brengen. Genoeg zij het daarom 
slechts te herinneren, dat Wolterbeek met den Sultan dd. 26-28 November 1818 een nieuw contract wist te sluiten, waarbij onze souvereiniteit erkend en Farquhar's contract vernietigd werd; zoo waren wij op Riouw en bleven er ${ }^{12}$. De volte-face des Sultans, die immers pas drie maanden te voren zich met de Engelschen had verstaan! werd eerlang verklaard in een "manifest" dd. 25 Mei 1819, waarin de Sultan aan Raffles en Farquhar misleiding is verweten geworden ${ }^{13}$. Dit was natuurlijk een stukje van ons bestuur; evenals het manifest dd. 10 Maart 1819 van den sultan van Indrapoera tegen ons gezag een Engelsch redacteur had gehad, gelijk ik op bl. 228 mijner verhandeling over Sumatra's Westkust te kennen gaf (ov. 24): kortom, altijd diefjes, met diefjes maat.

III.

Bij Wolterbeek's vertrek van Malakka was zijn medecommissaris als onze gouverneur er gebleven. Diens naam had door bijzondere omstandigheden vroeger geleden; nochtans, op voorspraak van den Schout-bij-Nacht, zag hij zich door de Regeering voor de gewichtige betrekking te Malakka aangewezen, en toen nu Wolterbeek hem van Batavia ook het op Riouw behaald succes kon melden, had Thijssen de overtuiging, dat zijn naam in eere hersteld was en schreef hij dientengevolge dd. 3 Januari 1819 een brief aan zijn beschermer, overvloeiende van betuigingen van dankbaarheid ${ }^{14}$. Als men echter deze en andere particuliere letteren leest van dien "heilbiddenden vriend", die, "waarde vriend!" schrijft hij aan Wolterbeek "uwe vrienschap" zoo hoog op prijs stelt; en dat gezemel in eenzelfden zin en altijd weder terugkeerend, dan kan men van zich den indruk niet afzetten, dat aan het hoofd van ons nieuw gouvernement geplaatst was een aartsvervelende femelaar.

Commissarissen-Generaal vertrouwden eene beste keuze te hebben gedaan. "Het bestuur van Malakka", schreef Elout dd. 10 Mei 1818 particulier aan den departementschef voor de Koloniën, "zullen wij opdragen aan den heer Timmerman Thijssen; hij is dáár en in den omtrek bekend, door den generaal Daendels daar gebruikt, en door den heer Raffles als een kundig koopman in zijn werk geprezen. Zoo wij ons niet bedriegen, zal die keus goed uitvallen" (V. D. 245). Inderdaad scheen zij aanvankelijk gelukkig; zelfs van Engelsche zijde althans werd den Nederlandschen gouverneur 
lof om zijn tact in den omgang toegebracht; doch het oordeel onzer Regeering wijzigde zich geheel, toen Thijssen het over Singapore te kwaad kreeg. Tot dusver is namelijk Timmerman Thijssen voor den man gehouden, aan wien het moet worden toegeschreven, dat Singapore niet door ons werd teruggekregen.

De afkeurende woorden omtrent dezen ambtenaar door lord Hastings in zijne missive aan Van der Capellen van I6 April 1820 gebezigd 15, vinden wij in een brief aan den heer Falck, Batavia, I9 Juni I824 van den Luitenant-Gouverneur De Kock bevestigd, als hij schrifft: «had hij, Timmerman Thijssen, verstandige maatregelen genomen, wij zouden Singapore nimmer hebben verloren, en Malakka zoude waarschijnlijk ook uit een ander oogpunt beschouwd zijn".

Alzoo de heer Spengler op bl. 99 zijner dissertatie. Wị zouden echter moeten weten, welke verstandige maatregelen De Kock eigenlijk op het oog had. Meende hij er mede voorzorgsmaatregelen als het tijdig stellen van eene kleine politiewacht op of om Singapore vò̀r de inbezitneming? Dan is het de vraag of de Gouverneur daartoe de middelen bezat, dan wel of van hem, die pas was opgetreden, voldoende kennis kon gevorderd worden om te mogen verwachten, dat hij voor het gevaar een geopend oog had. Een feit is het, dat de Regeering hem deze overigens te betreuren nalatigheid niet heeft verweten, toen zij er anders wel in een humeur voor was; ook dat de Regeering zelve hem op geen gevaar hoegenaamd heeft gewezen, ofschoon men te Batavia op de hoogte kon zijn, gelijk nader zal blijken. - Bedoelde wellicht De Kock een optreden als Muntinghe tegen Salmond, althans het zenden van gewapenden derwaarts? Zeker, het zou eene respectabele daad geweest zijn, maar alweder is het een feit, dat de Regeering hem juist heeft verweten hardhandig te willen optreden en dat men te Batavia nog destijds de bezetting had kunnen bevelen, dat men dit met succes had kunnen doen, vò̀r het dus te laat ware. Zonder er meer van te weten, beschouw $\mathrm{jk}$ het uit dien hoofde, dat Thijssen's naam onverdiend ten deze is besmet geworden; hij was geene buitengewoon krachtige persoonlijkheid: zijne vervelende particuliere brieven wijzen er duidelijk genoeg op; doch zóóver te gaan om hem de schuld van het verlies te geven, terwijl de deur voor onze Regeering eenige weken nog openstond om geweld met geweld te wreken, hiervoor vond ik tot dusver geen voldoende reden

Aan de geschiedenis der stichting van Singapore hoop ik eerlang. 6e Volgr. V. 
ook aan de hand der stukken van Bisschop's verzameling, eene afzonderlijke verhandeling te wijden; hier geef ik slechts in een paar regels de hoofdfeiten weder, namelijk voor zoover zij strekken om het karakter van een karakterloozen papieroorlog te kunnen begrijpen.

Raffles, uitvoering willende geven aan de te Calcutta noode gegeven machtiging om oostwaarts van Malakka eene Engelsche vestiging in het leven te roepen, was rechtstreeks van Vóór-Indie naar de Straits gestevend. Maar zijne machtiging ging niet verder dan buiten de sfeeren van het Nederlandsch gezag volstrekt te blijven. Troepen voor ondersteuning zijner expeditie aan te vragen, ware daarmede geheel in strijd en zou het wijfelend bestuur van Calcutta de oogen geopend hebben voor de waudaad, die Raffles feitelijk op het oog had. Misleidende zijn landvoogd en diens raad omtrent onze rechten en zijne bedoelingen, schroomde hij niet nog op de reede van Calcutta eigenmachtig te grijpen in het militaire oppercommando van zijne chefs, door van daar in alle stilte aan een naar Sumatra's Westkust te vertrekken schip eene aanwijzing naar Benkoelen mede te geven, om de troepen, die ter aflossing van Sumatra naar Bengalen terug zouden gaan, de reis te laten maken om de zuid van Sumatra, ten einde ze in de Straits te kunnen ontmoeten en hun hulp zoo noodig in te roepen. Dit schrijven bereikte echter Benkoelen eerst in Maart 1819. Toen bij brief van der Gouvernementssecretaris dd. 10 Juli 1819 de regeering te Calcutta Raffles gelastte om over dit gedrag opheldering te geven ${ }^{16}$, verantwoordde hij zich dd. 31 December d.a.v. op de gewone dubbelhartige wijze, die 's mans daden en schrijven zoo veelvuldig kenmerkten: hij had het eigenlijk niet gedaan, en toch ook wel gedaan ${ }^{17}$. De Regeering nam met zijne verontschuldiging geen genoegen; zij deed hem bij schrijven van den Gouvernementssecretaris dd. 22 Juli 1820 ernstig berispen ${ }^{18}$.

Bij het verlaten van Calcutta, had Raffles nog geene bepaalde gedachte omtrent de plaats zijner vestiging. Riouw stond wel op het progranma, doch dit moest door hem, in de Straits komende, worden opgegeven, wijl de Nederlanders de plaats hadden ingenomen. Hij schijnt toen het plan te hebben gehad naar Singapore te stevenen, waaraan hij mede reeds bij zijn vertrek van Calcutta gedacht had. "My attention is principally turned to Johore", schreef hij van Calcutta"s reede dd. 12 December 1818 aan vriend Marsden (Memoir bl. 374), "and you must not be surprised if my next letter to you is 
dated from the site of the ancient city of Singapura"; evenals Menangkabouw schetst hij de plaats als eene antieke, klassieke vestiging, die hij uit de studie van Maleische geschriften had leeren kennen; alzoo weer een lief punt voor lofredenaars. Hoe ook, hij begon met Singapore ter zijde te laten en elders zijn fortuin te zoeken. Majoor Farquhar namelijk had reeds in October 1818 op de Karimons eene vestiging voorgesteld, doch het Pinangsch bestuur verwierp het plan als "fantastic and injudicious". Farquhar bleef echter zóó zeer aan het denkbeeld hechten, dat hij bij Raffles, die hij in de Straits ontmoette, aandrong om eerst naar die eilanden voor het groote doel te stevenen. In de tweede helft van Januari 1819 ging inderdaad Raffles derwaarts; hij liet bovendien de gelegenheid opnemen door den Compagnie's kapitein Ross. Diens rapport was ongunstig. Een van Ross' equipage schreef: "Carimon is a perfect jungle, and not calculated for a settlement". Farquhar gaf nu toe en volgde Raffles in den vrijbuiterstocht naar Singapore, behoorende aan dienzelfden sultan van Djohor, waarmede Farquhar kort te voren een verdrag van eeuwige vriendschap had gesloten, en die ook door Raffles, tijdens het luitenant-gouvernementschap over Java en onderhoorigheden, steeds als de wettige sultan erkend was.

$\mathrm{Nu}$ echter bedachten de heeren zich, dat er een oudere broeder bestond, een zekere Toekoe Long, een man, die met goedkeuring van alle rijksgrooten, van belanghebbende zelf, van de vroegere Britsche regeering te Batavia, nooit voor den kroon in aanmerking was gekomen. Dit hoofd wist men door geld en beloften te bewegen van Riouw, waar hij rustig zat, naar Singapore clandestien over te steken. Raffles erkende er hem als vorst van Djohor, en liet hem in die qualiteit afstand doen van het eiland Singapore, waartoe verder de ons ondergeschikte onderkoning van Djohor medewerking verleende! 19 Toen de comedie was afgespeeld, schreven Toekoe Long en de Onderkoning brieven naar Riouw, dat men het hun niet kwalijk moest nemen, doch zij waren door Raffles en de zijnen bang gemaakt ${ }^{20}$. Als later onze Regeering zich op die correspondentie, welke de Sultan overlegde, beriep om het schandaal te bewijzen, werd door majoor Farquhar aan den gouverneur van Poeloe Pinang, die de gansehe zaak afkeurde, een stuk van Toekoe Long gezonden, waarin deze verklaarde, dat hij dit maar had geschreven, om zich te dekken voor het geval de Engelschen verplicht zouden worden hunne biezen te pakken ${ }^{21}$ ! 
IV.

Bij het vernemen dat de Engelsche vlag dd. 29 Januari 1819 op het eiland Singapore was geheschen, had de Gouverneur van Malakka verbolgen brieven, zoowel aan Raffles als aan den Gouverneur van Pinang geschreven, naar lord Moira's later oordeel, blijkens brief dd. 14. Januari 1820, in indliscreet language; alsof niet Raffles aanhoudend door zijne brutale brieven en maatregelen het Nederlandsch gezag beleedigde. Raffles antwoordde eerst dd. 17 Februari 1819 en wel van Prins of Wales' eiland. Hij zond hem afschrift van de nit Calcutta medegebrachte machtiging, die ik sub 63 mijner verhandeling over Sumatra's Westkust wedergaf; verder verwees hij hem naar hoogere autoriteit ${ }^{22}$. Natuurlijk zond Thijssen ook direct rapport naar Batavia, met zoodanige inlichtingen als hij destijds in staat was te geven, m. a. w. onvolledig, waarover de Regeering hem berispte. Of echter de Gouverneur in de gelegenheid was geweest zich eerder en beter op de hoogte te stellen, is mij onbekend. Ook Wolterbeek kreeg van hem een brief, gedagteekend 3 Februari 1819; daaruit zien wij, dat de Gouverneur militaire maatregelen had bevolen, evenwel niet rechtstreeks tegen Singapore, doch hij had zich bepaald met troepen naar Riouw te zenden, en de inlandsche vorsten tot eene expeditie tegen de vrijbuiters aan te zetten ${ }^{23}$. Ook mij komt het voor, dat dit wellicht minder gelukkig gezien was, maar de Regeering heeft hem hiervan evenmin een verwijt gemaakt; wat zij in hem laakte, was, dat hij aan militaire dadelijkheden had durven denken en dat hij... een brief aan een verkeerd adres had bezorgd! Een particulier schrijven dd. 21 Februari aan Wolterbeek doet dan ook zien, dat onze Gouverneur zich diep te leur gesteld gevoelt; het is echter niet de uiting van een man, die zich in de ontwikkeling zijner energie beleedigd acht ${ }^{24}$.

Den $13^{\mathrm{n}}$ Februari 1819 ontving de Gouv.-Gen. Van der Capellen het eerst de Jobstijding. Elout en Buyskes lagen reeds eenige dagen ter reede van Batavia om per Evertsen, begeleid door een paar andere schepen, de terugreis naar het vaderland te ondernemen. Ongunstig weder belette het uitzeilen, en zoo vernamen zij nog vòòr hun' vertrek de gebeurtenis, die zulk een overwegenden invloed op ons gezag in den Archipel zou uitoefenen. Ik kan den lust niet weerstaan het sober verhaal uit Wolterbeek's dagboek over te schrijven: 


\section{Januari.}

27. Ik ging ook heden aan boord om Hunne Excellentiën Commissarissen-Generaal op morgen af te wachten, zijnde hunne intentie om dan te embarqueeren voor de retourreis.

Den $28^{\text {n }}$ hadden we West à W. Z. W. regenachtig weer.

Tusschen 7 à 8 uur in den morgen kwamen H. H. E. E. de Commissarissen-Generaal met een sloep, waarvan de vlag woei, gevolgd door een aantal andere sloepen, op de reede. En werden door het vlaggeschip Tromp gesalueerd met 2 I schoten, paradeerende het volk in het want, en alle soldaten onder de wapenen. De Heeren Commissarissen gingen aan boord van $\mathrm{Z}^{\mathrm{r}}$. M $\mathrm{M}^{\mathrm{s}}$. schip Evertsen; en wierden aldaar door mij met alle commandeerende officieren bij mij gecomplimenteerd; waarna Z. E. de Gouverneur-Generaal weder naar den wal vertrok onder het paradeeren met het volk in het want...

Den $3 \mathrm{I}^{\mathrm{n}}$ kwamen Z. E. de commissaris Elout en de S. b. N. Buyskes bij mij op de Tromp aan boord, zonder honneurs als paradeeren.

De naar huis gedestineerde schepen wierden nu dagelyks volgehouden van water, en voorzien van ververschingen, doch de wind was zeer tegen.

Hadden deze gansche maand meest regenachtig weer, tusschen de buien broeiend, doch in den morgenstond vrij koel, zijnde de wind dan meest zuidelijk, doch flauw, loopende over dag van W.Z.W. tot N. W., waaruit de felste buien.

\section{Februari.}

Den $\mathrm{I}^{\mathrm{n}}$ westelijke wind, regenachtig weer. Het Nederl. commercieschip de Zeemeeuw, kapt ${ }^{\mathrm{n}}$ Wegener, ging onder zeil naar Europa, doch onder den westwal opgewerkt zijnde, ankerde, om den volgenden morgen van de landwind te profiteeren, loopende nu te westelijk.

Den $3^{\mathrm{n}}$ ging ik op de reede om te hooren of de schout-bij-nacht Buyskes ook nog eenige meerdere assistentie verlangde $(a)$; bevond dat de kapt $^{\mathrm{n}}$ Nooy de naar Europa gedestineerde schepen reeds met werpankers en kabeltouw geassisteerd had, doch de wind was en bleef van het Z.W. tot het N. W. En weinig of geen zuidelijk landwindje.

Den $5^{\mathrm{n}}$ arriveerde uit Holland het Nederl. commercieschip Flora, kapt $^{\mathrm{n}}$ Timan. Hadden dezen dag een geweldige bui van wind en regen uit het W. N. W.

Den $6^{\text {n }}$ werd de Evertsen op nieuw geassisteerd door de Tromp met sloepen, werpankers en kabeltouwen, doch zonder van nut te zijn, zooals tot den $\mathrm{I}^{\mathrm{n}}$ dezer dágelijks plaats had.

Den $1 I^{\mathrm{n}}$ de lekken op de Trom $p$ toenemende, liet ik zulks nader onderzoeken...

(a) Namelijk assistentie om te kunnen uitzeilen. 
Den $12^{n}$ ging ik met Z. E. den Gouverneur-Generaal op de reede om de heeren commissarissen Elout en Buyskes te bezoeken en inspecteerde de lekkage van de Tromp in persoon.

Den $13^{n}$ de wind in den vroegen morgen zuidelijk zijnde met kleine koelte, zonden sloepen en kabeltouwen ter assistentie naar de Evertsen en Prins Frederik, op welke schepen men ook op en neder wond (als ook zeilen bijzette), doch om 6 uur stil, en vervolgens het koeltje westelijker loopende, moesten weder blijven liggen.

Arriveerde een prauw van Malakka met brieven voor het Gouvernement. Z. E. de Gouverneur-Generaal deelde mij mede, dat de brieven van den Gouverneur van Malakka de tijdingen behelsden van het in bezit nemen van Singapore door de Engelschen. En nam zich voor op morgen nogmaals naar de reede te gaan om met de heeren commissarissen Elout en Buyskes deswegens te spreken.

Den $\mathrm{I}_{4}{ }^{\mathrm{n}}$ W. Z. W. à Westewind; betrokken lucht. In den vroegen morgen ging ik met Z. E. den Gouverneur-Generaal weder naar de reede, alwaar H. H. E. E. de Commissarissen-Generaal eene besogne hielden, omtrent de tijding aangaande Singapore.

$\mathrm{Na}$ afloop van welke zij mij verzochten om binnen te komen, verlangende informatie in hoeverre Singapore gerekend moest worden te behooren onder het gebied van den sultan van Linga, Riouw, etc.

Daar ik nu gepasseerde jaar het contract met den sultan van Linga en Riouw gesloten had, kon ik de meeste inlichting geven omtrent den ganschen samenloop van het gepasseerde op Singapore. En deed zulks. Als :

Dat ik met volkomen zekerheid kon zeggen Singapore-eiland te behooren onder het gebied van den sultan van Linga, omdat de vorstonderkoning van Riouw, gevolmachtigde van den Sultan tot de onderhandelingen, dezelve niet met mij wilde beginnen, dan nadat ook de Toemmengoeng van Djohor (zijnde het oudste der verbonden rijken en stamhuis der sultans van het geheele rijk, zoolang er prinsen van den bloede existeeren) gearriveerd zoude zijn, wijl de Sultan geene verbonden of eenige andere zaken van aanbelang bekrachtigde, indien de Toemmengoeng van Djohor, daarin niet had toegestemd; zoodat ik moest wachten tot de komst van dien Toemmengoeng, welke afgehaald is door den kroonprins van het rijk van Djohor, liggende het eiland Singapore niet verder van die kust dan de breedte van een riviertje, hetwelk voor kleine vaartuigen eene veilige ligplaats geeft. En de bevolking in alles onder den Toemmengoeng van Djohor staande.

Dat wat aangaat het in bezit nemen der Engelschen van dat eiland, zulks eene zaak was, die niet vreemd moest voorkomen, wanneer men de missive door den heer Farquhar gepasseerde jaar aan de commissarissen ter overneming van Malakka en onderhoorigheden, dato 22 October geschreven, maar nagaat, vertrouwende ik de toedracht der zaak zal hebben plaats gehad, als: 
Dat de heer Farquhar, hoorende dat de Nederlanders bezit zouden komen nemen van Malakka, gebruik heeft gemaakt van een bij de neming van Malakka in $\mathbf{1} 795$ in zijne handen gevallen brief, door den toenmaligen gouverneur Couperus, aanduidende de intentie der hooge regeering om het rijk van Linga en Riouw onafhankelijk te verklaren. ${ }^{25}$ En sedert die inbezitneming in 1795 niets meer daaromtrent gehoord zijnde, den vorst van Riouw en Linga in de verbeelding heeft gebracht, niets meer met ons te doen te hebben. In welke overtuiging hij bij den Vorst vervolgens heeft aangevraagd een etablissement te mogen aanleggen op de Karimoneilanden of elders b/o Malakka, wanneer wij Malakka kwamen bezetten.

Dat de Vorst daarin heeft toegegeven; en de heer Farquhar dit consent heeft gecommuniceerd aan het Suprême Engelsch gouvernement te Bengalen, zonder meer.

Dat men dus wel kon denken, het Gouvernement van Bengalen, ziende dat de vorst van Linga zich zelf onaf hankelijk considereerde, en in de overtuiging zijner onafhankelijkheid, tot het afstaan van een etablissement b/o Malakka gekomen was, daarvan gebruik heeft gemaakt en een commissie gezonden met behoorlijke macht, om zulks uit te werken en te mainteneeren.

Dat het ook wel na te gaan is, dat de Karimoneilanden (klippen zonder baaien) alleenlijk maar dienden om de intentie van het eiland Singapore, reeds door een Engelschen Compagnie's zeekapitein Ross exactelijk opgenomen, en excellent voor zoodanig etablissement bevonden, af te wenden; doch het niet te denken was, dat het Suprême Gouvernement volledig bij die aanvrage is onderricht, omtrent de nog bestaande afhankelijkheid des Sultans, met zijn gansche rijk aan ons, hetwelk wij in ons antwoord aan den heer Farquhar op zijne missive dd. 22 October, ook ten volle dato 28 d. a. v. hebben geëxpliceerd ${ }^{26}$, komende, het mij dus voor, dat men het Engelsch gouvernement in Bengalen (daaromtrent geheel onkundig gehouden hebbende) tot het consent van zoodanige bezitneming heeft weten over te halen; hetgeen ook uit de discoursen door den heer Farquhar met ons deswege gehouden en verder etc. etc. wel op te maken is. Insgelijks dat ook het Suprême Engelsch gouvernement eenmaal daartoe consent, last en executie verleend hebbende, daarvan niet wel zoude kunnen terugkomen, zonder onderhandelingen der wederzijdsche Indische Gouvernementen.

H. H. E. E. Commissarissen-Generaal schenen mede van dit begrip te zijn.

16. $\mathrm{Z}^{\mathrm{r}}$. Ms schepen Evertsen, Prins Frederik en Maria Reigersbergen gingen onder zeil, doch moesten in het Z.W. van het eiland Hoorn weder ankeren...

Den $17^{\mathrm{n}}$ à $2 \mathrm{I}^{\mathrm{n}}$ hadden meest West à W. Z. W. wind, regen en slecht weer... 
Den $22^{\mathrm{n}}$ de wind in den morgen zuidelijk zijnde, avanceerden de te huis varende schepen daarmede tot b/o Haarlem...

Den $26^{\text {n }}$ passeerde de S. b. N. Buyskes met zijne onderhebbende schepen Ontoeng Java en raakte buiten het gezicht der reede.

Voor eene juiste kennis der Singapore-geschiedenis is Wolterbeek's verbaal opmerkelijk, zéér opmerkelijk.

Als hij zegt, dat de Engelsche bezoeken aan Karimon slechts een list waren om onze ausdacht van Singapore af te leiden, gelijk ik eerst ook op zijn gezag als een nieuw gezichtspunt aannam, dan blijkt het nu uit het op bl. 407 door mij medegedeelde, hetwelk men bij Boulger bl. 304 beschreven vindt, dat de Schout-bij-Nacht hier meer heeft verzekerd, dan hij tegenover de gesehiedenis zou kunuen verantwoorden; doch wat doet dit tot de zaak? Elk woord, dat Wolterbeek in die vergadering van den $14^{n}$ Februari 1819 zou gesproken hebben, moest, dunkt mij, op de afgetreden Commissarissen-Generaal den indruk hebben gemaakt van zoovele beschuldigingen over gemis aan doorzicht. Hij zeide het immers: men kon wel op zijne tien vingers natellen, dat men iets anders dan Karimon op het oog had; men wist dat Singapore nauwgezet was opgenomen door de Engelschen: exactelijk; men wist dat Singapore eene uitnemende haven aanbood: excellent; en deu $19^{\text {n }}$ December 1815 was Wolterbeek zelf te Batavia terug...

De voldoening over de rustige teruggave van Malakka scheen echter ons bestuur in slaap te hebben gewiegd. "De overgave van Malakka is ons daarom vooral aangenaam geweest te vernemen", schreef de Gouv.-Gen. nog dd. 7 November 1818 aan den Minister van Koloniën (Spengler bl. 93), "omdat velen dachten dat de heer Raffles op den Gouverneur van Poeloe Pinang zoude hebben trachten te influenceeren om de vertraging der overgave te bewerken." - Hoe, rijst onwillekeurig in de gedachte, kon men anders met al de wetenschap voor zich, die Wolterbeek beweerde te hebben, Singapore en omgevende eilanden rustig zonder zeepolitie laten; waarom, indien men voor het minste slechts vreesde, niet te Singapore een waker met onze vlag gesteld, op slechts... vijf en twintig gulden in de maand? Hoe kon Van der Capellen dd. 6 Maart 1819 onzen Koning in gemoede over Singapore's stichting schrijven: "Het is even moeilijk als onraadzaam alle punten, alle kleine eilanden bijvoorbeeld in straat Malakka, te bezetten. Maar indien op eenige geen Nederlandsche vlag waait, of geene bezetting geplaatst is, moeten daarom onze naburen, met 
welken Uwe Majesteit in volle vrede en vriendschap leeft, zich die omstandigheden ten nutte maken, om aldaar de Britsche vlag te planten en eene bezetting te leggen? Op die wijze zouden de tooneelen van vorige eeuwen zich kunnen vernieuwen en de Oost-Indische zeeën het tooneel van aanhoudenden kleinen oorlog worden, terwijl tusschen de Gouvernementen zelven eensgezindheid en vrede heerscht." 27 In algemeenen zin was dit zeker zeer juist; doch het blijkt ons nu uit Wolterbeek's verbaal van de gehouden conferentie, dat Singapore niet tot alle punten, tot alle kleine eilanden mocht worden gerekend, en dat men dit tijdig genoeg heeft kunnen weten om voorzorgsmatregelen te nemen, - maatregelen te gebiedender, na de ervaring in de Lampongs en te Palembang opgedaan; na hetgeen geschied was met Padang; na Wolterbeek's vernietiging vooral van het Engelsch contract op Riouw.... Why did they so long neglect it? - was ook onder deze omstandigheden de niet onnatuurlijke vraag, die uit het vijandelijk kamp over Singapore tot ons rees, toen van Nederlandsche zijde tegen de bezetting werd opgekomen. 28

Intusschen als men des nachts zijne woning laat openstaan en dieven maken daarvan gebruik, dan zullen de bewoners, indien zij de deugnieten verrassen en zich sterk genoeg gevoelen, de bende met geweld oppakken en overleveren, waar het behoort; men zal niet gaan onderhandelen, niet gaan vragen: och, doet ons toch als je blieft het plezier om weer heen te gaan! - Ziedaar, tegenover Wolterbeek's verzekering, dat wij sterk genoeg waren, de duistere, roemlooze vlek, die op de Nederlandsche koloniale geschiedenis dier dagen rust, die door al het water van de schoone Straits niet weggewasschen kan worden.

"Ik vrees", schreef mij een zeer verdienstelijk publicist dd. 28 Februari 1898 uit Zuid-Afrika, aan wien ik mijn Gidsartikel over Palembang had gezonden en die vermoedelijk van dezen papieroorlog niets weet: "Ik vrees dat heel wat droeve bladzijden zouden geschreven kunnen worden over het onbevredigd optreden der Nederlandsche regeering tegen aanmatigingen van vreemden, gedurende deze eeuw. Al te groote voorzichtigheid wordt meestal door tegenstanders opgevat op eene weinig vleiende wijze, en het groote koloniaal succes der Engelschen is in den regel meer toe te schrijven geweest aan brutaliteit dan aan macht." - Nu tot die heel wat droeve bladzijden behoort ook de geschiedenis der stichting van Singapore.

Pas een half jaar te voren was door Commissarissen-Generaal, 
naar aanleiding van den Salmond-inval aan het Opperbestuur geschreven: "Zulke feitelijkheden kunnen herhaald worden : zij kunnen van meer dadelijken invloed op de rust en veiligheid der Nederlandsche bezittingen worden: zij kunnen een oogenblikkelijken en krachtdadigen tegenstand noodwendig vorderen. En dan wordt het voor de Indische regeering eene der neteligste omstandigheden, hoe, zonder den wil en de begeerte van het Europeesche gouvernement te kennen, te handelen. Het wordt voor haar dan een raadsel, wat te doen, wat te laten." - En een paar weken later smeeken zij opnieuw, "ten ernstigste", om hen toch ten deze van bevelen te voorzien. ${ }^{2}$ De Singapore-geschiedenis kwam dus niet op als een donderslag aan helderen hemel; onze Regeering kon zich op alles voorbereid achten. En was dan de Salmond-opzending zoo slecht afgeloopen, dat wij ons daarover hadden te berouwen? Integendeel, alles drong er toe, zou men zeggen, om vóór de bevelen uit Nederlaud kwamen, te besluiten: wanneer zich een dergelijk geval andermaal voordoet, zal men hetzelfde moeten doen. De lof, dien C. C. G. G. aan Muntinghe's beleid in deze, volkomen verdiend trouwens, toebrachten, was immers daarmede in volkomen overeenstemming. Hier was eene rlaal verricht van zelfbewuste kracht, zooals men in een gansch ander genre gezien had, toen men in glorierijker tijden, onze oorlogschepen durfde doen spelevaren in de Theems. Wat moet er bij onze bewindslieden zijn omgegaan, toen eindelijk de antwoorden uit Nederland kwamen, bevattende 's Konings uitdrukkelijk verlangen, dat geweld met geweld zou worden gekeerd, terwijl berusting reeds het pleit had doen verliezen. De minister van Koloniën Falck had toch geen oogenblik geaarzeld onzen Vorst den eenigen juisten weg aan te wijzen. "Mij komen", schreef hij immers, "deze wil en begeerte niet twijfelachtig voor en ik hoop, dat C.C. G. G. zich zullen hebben overtuigd, dat geene plicht of zorg hooger staan moet dan die om de rechten van den Staat voor verkorting of miskenning te bewaren." 30 En in dezen geest sprak de Minister dd. 5 Februari 1819 bij de Indische regeering het vertrouwen uit, lat zij den te Palembang gevolgden weg tegenover de Engelschen steeds zou bevandelen: "en dienvolgens ook de wettige belangen van Nederland, op alle punten, waar dezelve door hen aangerand zijn of alsnog mochten worlen, te doen gelden met dien nadruk en met die omzichtigheid tevens, welke alle de matregelen van het Indisch bestuur, nopens de onderhavige geschillen, zoo voordeelig hebben geken- 
merkt" ${ }^{31}$; een schrijven eerlang gevolgd door dat van 2 Maart 1819, waarin dezelfde Minister het zich tot een aangenamen plicht verklaarde, aan den Gouv.-Gen. niet slechts kennis te geven van "s Konings volkomen goedkeuring" met ons cordaat optreden te Palembang, doch tevens van: "Zijner Majesteits begeerte, dat in alle soortgelijke omstandigheden, die zich onverhoopt verder mochten opdoen, de rechten en belangen der natie en de waardigheid van den Nederlandschen naam in gelijker voege met bedaardheid en nadruk tevens worden gehandhaafd." 32

In alle soortgelijke omstandigheden handelen in gelijker voege!! Zou men het willen gelooven, dat dezelfde man, die te Malakka en in den Riouw-archipel zoo beleidvol en krachtig was opgetreden, nu onze Regeering een gansch verkeerden weg van nationale flauwhartigheid deed opgaan?

Wolterbeek's eigen journaal zegt er niet veel van; men zou erg tusschen de regels door moeten lezen, om te kunnen bevroeden, wat eigenlijk heeft plaats gevonden. Immers wij lazen op bl. 410, dat hij in de vergadering der gewezen Commissarissen-Generaal, ons goed recht op Singapore boven alle bedenking stelde; dat dan ook ongetwijfeld de Britsch-Indische regeering, die tot de daad zou gemachtigd hebben, door Raffles weder was misleid; doch dat men, nu eenmaal de machtiging werd verleend en tot uitvoering gebracht, "daarvan niet wel zoude kunnen terugkomen, zonder onderhandelingen der wederzijdsche Indische gouvernementen". En daarop volgt enkel de mededeeling, dat C. C. G. G. mede van dit begrip schenen te zijn! Een weinig gelukkige gedachtengang in eene vergadering, belegd voor de vraag: "wat te doen"?

Men vindt echter de aanvulling in de op bl. 393 vermelde levensbijzonderheden van Wolterbeek. Daar wordt ook melding gemaakt van de vergadering op het linieschip Ever/sen, van het binnenroepen van den Schout-bij-Nacht, en van zijn betoog ten aanzien van de onbetwistbaarheid onzer rechten op Singapore. Vervolgens lezen wij echter het onderstaande op bl. 306; de zaak is voor onze geschiedenis van te groot belang om het medegedeelde niet letterlijk weer te geven :

De Heeren Commissarissen-Generaal waren hierop van gevoelen, het van hunnen plicht te moeten rekenen, om maatregelen te nemen, ten einde de Engelschen te verplichten, en desnoods met geweld te noodzaken, zich weder van daar te verwijderen, en welke taak zij aan den schout-bij-nacht Wolterbeek opdroegen. 
Hoe vereerend voor hem ook het hierdoor in hem gesteld vertrouwen was, en in welks uitvoering geene zeer groote moeielijkheid kon gelegen zijn, uit hoofde dat de macht, die hiertoe ter zijner beschikking zoude kunnen gesteld worden, die der opgegevene sterkte der Engelschen aldaar verre overtrof, zoo achtte hij het niettemin van zijne verplichting, meer de bijzonderheden open te leggen, waarmede deze willekeurige daad van het Britsch-Indisch bestuur naar zijne meening in verband kon staan, welke hem tijdens de overname van Malakka ter kennisse waren gekomen, en tot welke de langdurige afwezigheid van den resident Farquhar en zijne rondreize bij de vorsten aldaar had gestrekt; waarbij in aanmerking kwam, de kwalijkgezindheid van den gewezen luitenant-gouverneur van Java, Sir Stamford Raffles, jegens ons Gouvernement, waardoor wellicht het opperste bestuur te Bengalen ten aanzien van den stand der zaak verkeerdelijk zoude zijn ingelicht, en dienvolgens aan het Gouvernement in Engeland zelf, en waarbij de positie van den vorst van Djohor jegens ons, verkeerdelijk voorgedragen konde worden, en alzoo eene verdrijving der bezetting van Singapore wellicht ernstige represailles in Europa, van Engeland jegens ons, zoude kunnen uitlokken; bij voorbeeld, een embargo op de pas herlevende Nederlandsche koopvaart, zoo lang de zaak niet door meer juiste berichten en inlichtingen van onze zijde opklaarde, waarmede veel tijd zoude verloopen. Hij gaf om de voormelde redenen in bedenking, of het niet voorzichtiger zoude zijn, om, in stede van maatregelen van geweld te bezigen, de zaak tot eene gouvernementsquaestie te maken, hetzij door briefwisseling of onderhandeling tusschen de opperbesturen der beide landen in Indië; of wel, om tusschen de Gouvernementen der beide volken in Europa te worden beslecht, waartoe de terugkeer naar Nederland der twee heeren Commissarissen-Generaal bijzonder de gelegenheid aanbood, en om alzoo de anderszins te vreezen botsing tusschen de bevriende rijken voor te komen.

De Gouverneur-Generaal met de beide heeren CommissarissenGeneraal stemden volkomen in met dit advies, hetzelve alleszins welberaden en voorzichtig keurende, en er werd bepaald, dat dienovereenkomstig maatregelen zouden worden genomen.

Hebben de Evertsen's en de Tromp's, die zulk eene zwakhoofdige taal van een zeeman moesten aanhooren, er niet bij gezucht, geweeklaagd! Waren dat nu de mannen, die naar Elout's vroegere uitspraak nogal wat aandurflen ${ }^{33}$; ja zelfs bij Fendall's bezwaren tegen onmiddellijke overgave van Java, er waarlijk aan gedacht hadden om dat eilund eenvoudig te nemen ${ }^{34}$ ! Was door die fatale Palembangsche geschiedenis, waarin moreele fouten ontegenzeggelijk gemakt waren ${ }^{35}$, en die ons toenemend zou drukken, de geestkracht 
nu reeds verdwenen? - Maar hadden C.C.G. G. niet tevens op de eigen reede van Batavia een paar dagen te voren lord Moira's brief ontvangen, houdende niet slechts af keuring van Raffles' gedragingen doch ook deze woorden: "We should have seen nothing to object too in Captain Salmond being directed to return to Fort Marlborough, an order which it would have been his duty to obey" ${ }^{3} 6$ : eene aanmoediging voorwaar ook van die zijde om nu hetzelfde te doen! Zoo vreemd komt de houding van C.C.G.G. mij voor, dat de vraag rijst, of Muller's mededeelingen wel geheel juist of liever volledig zijn. Is het ook wellicht de heer Van der Capellen geweest, die hier den doorslag naar den verkeerden kant gaf; hij was een diplomaat, en diplomaten onderschatten soms het gewicht van een onverwijld handtastelijk optreden. Elout geeft in zijn brief dd. 9 Juni 1818 de vrees te kennen, dat als hij den rug zal hebben gekeerd, er minder krachtig wellicht zal worden opgetreden: "Zoo wij, die nog al durven op ons nemen, huiverig zijn, hoe dan hierna de Hooge Regeering?" en laat daarop volgen, dat de tijd hem verbiedt "uit te weiden" 33 . - Doch er staat tegenover, dat zij die nog al durfden, Raffles in het midden van 1818 wederrechtelijk de vlag in de Kalambajang-baai in de Lampongs hadden laten wapperen, zoomede zich laten verbieden, dat ook wij er onze vlag plantten, en dat toen precies hetzelfde werd gedaan, als een halfjaar later ten aanzien van Singapore, d.w. z. pro-tes-teeren. In ieder geval, aangenomen dat C. C. G. G. eenstemmig hebben gedacht over de Singapoorsche geschiedenis, Van der Capellen draagt er uitsluitend de verantwoordelijkheid van; want het op de reede van Batavia gegeven advies was feitelijk niet meer van de Commissie-Generaal, die zich immers den $16^{\text {n }}$ Januari 1819 ontbonden had verklaard, doch van particulieren, aan wier oordeel de Landvoogd zich ten slotte niet behoefde te storen.

Zeker er waren wel redenen om zich te vleijen, dat, ook zonder militair optreden, het bestuur van Bengalen Raffles' daad zoude wraken, omdat hij immers over zijne andere willekeurigheden berispingen met practisch gevolg had ontvangen; maar er waren ook wel aanwijzingen, dat de afkeuring over Singapore geene ontruiming zou medebrengen. Thyssen schreef, naar wij uit den sub 23 vermelden brief van 3 Februari kunnen lezen, dat, wilde het niet te laat zijn, "spoedig redres" vereischt werd; Wolterbeek zelfs wees op de waarsohijnlijkheid. van onderhandelingen, naar wij zagen (bl. 411); Van der Capellen zag eindelijk ook, blijkens sub 60 en 
61 te vermelden brieven dd. 9 November en 16 December 1819 de toekomst donker in, nu dat wij niet aanstonds de daad bij het woord hadden gevoegd.

En sprak het nu zoo vanzelf, dat een militair optreden onzerzijds onmiddellijk een strijd zou tengevolge hebben, waarin wij de aanvallers moesten zijn? Wanneer wij volstrekt bedaard en voorzichtig wilden handelen, - dat zijn immers de alle initiatief en geestdrift doodende woorden der administratie - dan zou onze Regeering van den eigen Raffles kunnen geleerd hebben, hoe wij behoorden op te treden. Immers in de Semangka-baai van de Lampongs was nog zoo lang niet geleden, door hem de Britsche vlag tegenover de onze geplant Wij hadden dit ten minste evenzeer op Singapore kunnen doen. Het plaatsen eener militaire wacht, niet om te verjagen, doch om de verdere ontwikkeling van het voldongen feit te beletten, te belemmeren - het eenige ook trouwens wat wezenlijk noodig zou geweest zijn - waardoor de grootere beteekenis van Singapore niet zoo glashelder aan den dag ware getreden, had ongetwijfeld zeer vruchtdragend kunnen blijken. Men leest toch in alle stukken dat geene enkele toongevende Engelsche autoriteit, die in deze zaak buiten Raffles zou to beslissen hebben gehad, hetzij in de Straits zelve, hetzij in Britsch-Indië, hetzij in Engeland, militaire verwikkelingen ten onzen koste zou gewild hebben, dat alle gezaghebbenden tot iederen prijs dat wilden vermijden. Eene enkele krijgshaftige daad van Nederlandsche zijde zou de gansche zaak niet alleen tot den normalen staat teruggebracht, doch tevens voor goed ons van Raffles verlost en zijn naam voor de geschiedenis bedorven hebben. Daar had men in de eerste plaats het bestuur der Straits zelve, kolonel Bannerman. Men zoekt in zijne weinige ingenomenheid met Raffles' grooter Engeland, persoonlijken naijver, doch het komt mij boven twijfel voor, dat het grondverschil tusschen beide mannen lag in grootere nauwgezetheid van den Britsehen officier, die plichtmatig naar gegeven bevelen hoorde en zich aan schending van andermans rechten ergerde. Ook hij, zoo goed als Raffles, rreesde eene te uitsluitende heerschappij der Nederlanders in den Archipel, en had daarom naar Perak, Salangor, Borneo, Riouw, Siak commissiën gezonden voor het sluiten van tegen ons gerichte contracten; doch met de aanwijzing dat de Nederlandsche rechten moesten geeerbiedigd worden: "that the Netherlands Government could not raise an equitable claim to it afterwards", gelijk men in Bisschop's verslag bl. 200 herinnerd vindt. Maar Raffles kende zulk eene 
eerlijke zelfbeperking niet. Voor hem was ieder middel, dat slechts doel trof, goed. Een principieel verschil in opvatting, die reeds voldoende de wanverhouding tusschen beide mannen verklaard; en die, in diepgewortelde overtuiging over Raffles' onrechtvaardig streven tot vestiging bezuiden Malakka, Bannerman, nog vòòr de stichting, naar Calcutta deed schrijven, dat de Nederlanders nooit de bezetting zouden toelaten, dat onze rechten onbetwistbaar waren, dat het gansche denkbeeld weder was een van "Sir Thomas Raffles" aberrations" 37. De Gouverneur van Poeloe Pinang stond hierin niet alleen. Lord Moira toch was woedend over de stichting. Hij verklaarde het onzen Landvoogd eene gemeene daad te zijn; hij schreef Bannerman dd. 20 Februari 1819: "Sir Thomas Raffles was not justified in sending major Farquhar eastward, after the Dutch protested; and, if the post has not yet been obtained, he is to desist from any farther attempt to establish one" ${ }^{37}$. Het bestuur der O. I. Compagnie te Londen berispte lord Moira dd. 22 Mei 1819 aldus op het vernemen der zending: "We express our decided disapprobation of the extension in any degree to Eastern islands of that system of subsidiary alliance which has prevailed, perhaps too widely in India" ${ }^{38}$; en als de stichting daar bekend wordt, rijst de verbolgenheid: "Any difficulty with the Dutch", schreven Directeuren dd. 14 Augustus 1819, "will be created by Sir Stamford Raffles' intemperance of conduct and of language"; zij zouden slechts nadere berichten afwachten "before retaining or relinquishing Sir Stamford Raffles' acquisition" 38 . President van de directie was' minister Canning; hij was onder den eersten indruk evenzeer woedend, en dat uitsluitend omdat men een militair optreden vian Nederlandsche zijde verwachtte, vreesile tot zekere mate, omdat men ons in Europa welgezind was.

$\mathrm{Er}$ is meer ten bewijze, dat geen leste stuurman aan wal hier kan beoordeelen, hoezeer ons flauwhartig optreden, uitgedrukt in het geheim gouvernementsbesluit, gedagteekend Batavia, den $25^{\mathrm{n}}$ Februari $1819 \mathrm{l}^{\mathrm{t}} \mathrm{A}$., de diepste afkeuring tegenover de geschiedenis verdient: een zemelend stuk, waarvan de lezing slechts weeheid en weemoed wekt. Gouverneur Timmerman Thijssen, die wel vooruit gewild had, kreeg velerlei aanmerkingen: hij was niet welberaden noch voorzichtig immers! "Wij moeten", luidde de verpletterende hoogwijsheid, "hetgeen wij bezet hebben, door de noodige macht tegen de aanvallen van allen en tegen de woelingen der inlanders beveiligen. Wij moeten door onze bedaarde houding, met eene 
goede macht ondersteund, het behoorlijk ontzag voor de Nederlandsche regeering inboezemen. Geene dadelijkheden behooren door ons gepleegd te worden..."! Besloten werd dus : $1^{\circ}$ Het bestuur te Calcutta in te lichten en het "dringend" te verzoeken, dergelijke onhebbelijke daden niet toe te laten; $2^{\circ}$ Den Gouverneur van Malakka te berispen; $3^{\circ}$ Hem op te dragen "eene beleefde missive" naar de autoriteit op Singapore te zenden, houdende herinnering, dat ze zich heelemaal vergiste, daar ze op een andermans stoel zat, met verzoek natuurlijk er vandaan te gaan en bij weigering te... pro-tes-tee-ren! Maar die "beleefde missive" is dan toch het mooiste; $4^{\circ}$ den onder-regent van Djohor, die ons verraden en zich aan de vrijbuiters verkocht had, te beknorren! En eindelijk: "Zoodra de mousson het zal toelaten eene gewapende zeemacht naar Malakka te zenden, om zich in die wateren te vertoonen, en de inlandsche vorsten aan hunne verplichtingen te herinneren; voorts het garnizoen van Malakka en Rionw op eene goede sterkte te houden"! 39

Militaire maatregelen zouden derhalve toch niet uitblijven, en de geruchten daarvan deden weldra de ronde in de Straits. Maar daar wist men niet, dat het nageslacht der De Ruiters op een lief lantwindje zoude wachten om roovers te verdrijven; dat het was om de vlag te gaan vertoonen; om een paar garuizoensplaatsen, die heelemaal niet bedreigd werden, nog te versterken; om vriendelijke brieven te schrijven, dringende verzoeken te doen, klinkeude protesten te doen hooren; om zure gezichten te zetten tegen ongezeggelijke inlanders :- daar in Singapore en omgeving moest men wel denken dat het nu terdege zou gaan spannen. De Engelsche zeekapitein D. Ross had van onze krïgshaftige voornemens op het laatst van Februari 1819 te Malakka zelf gehoord en er bij brief dd. 6 Maart van kennis gegeven aan het bestuur te Singapore, waar majoor Farquhar, bij afwezen van Raffles, het hoogste gezag voerde. ${ }^{40}$ In allerijl, nog denzelfden dag, zond Farquhar een dringend verzoek om hulp aan gouverneur Bannerman ${ }^{41}$. Merkwaardig, zeer merkwaardig is het antwoord van den Kolonel dd. 16 Maart: die treurige gevolgen waren wel te voorzien geweest, schrijft hij; op toezending van troepen behoefde men echter te Singapore niet te rekenen; er waren daar schepen genoeg om met pak en zak het eiland weder te verlaten ${ }^{42}$ ! En tegelijkertijd schrijft hij eene dringende bede aan Timmerman Thijssen om toch geen bloed te doen vergieten, daar alles wel weder terecht zou komen ${ }^{43}$ ! 
Zulk een verzoek was trouwens gansch overbodig: wij dachten niet aan bloedvergieten. Wij deden niets, absoluut niets. Nationale trots was en bleef uit. "Holland to day" zegt W. H. Titchet in zijn artikel over Blake and the Dutchmen in de Cornhill Magazine van Februari 1898 (bl. 146) "is a land without ambition, comfortable, fat, heavy bottomed. In the middle of the seventeenth century Holland proudly claimed to be the greatest naval power in the world, and by daring seamanship, great fleets, famous admirals, and a world-encompassing trade it went far to justify that boast." $4+$. $\mathrm{Nu}$ was dat alles anders.

Lord Moira, vain, weak and honest ${ }^{\mathbf{4 4}}$, ademde oumiddellijk ruimer ! De geopende papierbatterij tegen Calcutta behoefde men niet te vreezen: Bannerman moest dat begrepen hebben en daarom kreeg hij nu over zijne verhouding tot Singapore eene scherpe vermaning. "The opposition of the Dutch", luidde de typische mededeeling aan den Gouverneur, "was not of the nature which we had directed to be shunned under the description of collision" ! Brandende woorden... voor ons. Het Pinangsch bestuur zond toen troepen en geld: "but", erkent Boulger terecht (bl. 325), "as six weeks had elapsed between the original request and their departure, the reinforcement would have been too late, if the Dutch authorities of Batavia had endeavoured to treat major Farquhar at Singapore as they had treated captain Salmond at Palembang".

Terwijl de Bataviasche papierbatterij haar best deed, en door Calcutta slechts voor zoover werd beantwoord, dat wij er den moed niet onder verliezen zouden, waren slechts weinige maanden noodig voor de vestiging van de stad. Inderdaad met ongekende, ongedachte snelheid rees Singapore; rapport aan rapport van daar luidden als overwinningsbulletins: triomfeerende toonen, die men inderdaad het recht had te doen hooren ${ }^{45}$. Ternauwernood kon zich echter lord Moira de eer hiervan eenigermate toe rekenen; maar met de ongelijkmoedigheid aan zwakke menschen eigen, gaf dezelfde Britsche Landvoogd, die oorspronkelijk zoo ontdaan over de daad was geweest, eene laatdunkende getuigenis over onze grootere makheid, nu dat wij niet alleen niets anders deden dan schrijven, doch zelfs beleefd schreven! 46

Nochtans had ook onze Regeering eene overwinning behaald, waarmede zij zich feliciteerde, eene overwinning namelijk op haar zelve. "Het is inderdaad zeer gelukkig", schreef Gouv.-Gen. Van der Capellen an het Opperbestuur dd. 18 Maart 1819, waarbij 6e Volgr. V. 
zeker Timmerman Thijssen was vergeten, "dat de Nederlandsche ambtenaren, wien het tot nu toe te beurt viel den eersten schok dier aanrandingen te wederstaan, de zaken zoo geheel uit het ware oogpunt beschouwd hebben, dat er nog geene feitelijkheden hebben plaats gehad. Doch diezelfde gematigdheid, datzelfde koele beraad, kan niet in alle omstandigheden, bij alle personen verwacht worden; en hoe gaarne ik ook zoodanig tafereel voor onwaarschijnlijk wenschte te houden, voorzie ik toch, dat vroeg of laat uit deze collesiën de ernstigste gevolgen zullen geboren worden." $47 \mathrm{O}$ geen gevaar voor de Nederlandsche Bedaardheid, Koelheid, Beradenheid. Maar of de Gouv.-Gen. Van der Capellen en zijne vroegere ambtgenooten, of ook Wolterbeek zelf, over hunne gedragslijn nooit spijt gevoeld zullen hebben....? Het is alsof men met telkens op de betoonde gematigdheid terug te komen, zich zelven in zijn twijfel over het wijze van het beleid wil geruststellen. Van der Capellen deed het in zijn brief dd. 22 September 1819 an het Opperbestuur, er noor borg staande (in weerwil van Wolterbeek's expeditie naar Riouw, waardoor Farquhar's contract was vernietigd), dat "aan onze zijde noch geweld, noch intrige van welken aard ook gebezigd" is ${ }^{48}$; Elout deed het in de Londensche onderhandelingen, er aan herinnerende, dat de Britsche regeering onze kalme houding zoo bijzonder had gewaardeerd.... het laat zich begrijpen; en Van der Capellen schrijft het ruim een jaar na het gebeurde aldus particulier aan lord Moira:

"Dès la réception de la première nouvelle de l'expédition hostile de M. Raffles, contre une des possessions dépendantes de mon gouvernement, je crois pouvoir me rendre le témoignage d'avoir usé d'une grande modération. Que Votre Excellence se mette un moment à ma place, et elle me dira si, avec le moindre patriotisme, avec le moindre sentiment de sa propre dignité nationale, il eût été possible d'apprendre une pareille nouvelle sans éprouver la plus grande indignation, et sans être tenté de réprimer immédiatement un pareil attentat et de venger son honneur en usant de tous les moyens disponibles. Qui, mieux que Votre Excellence, rendra justice à ce premier mouvement? Je ne vous cache pas, Milord, que je l'ai éprouvé, et que j'ai dû me munir de tout ce que des considérations, tout aussi urgentes; me suggéraient d'une voix également forte, pour agir avec le calme nécessaire pour réprimer ce sentiment et me renfermer dans les bornes que mon devoir me prescrivait impérieusement. Je me suis done contenté 
de donner connaissance à Votre Excellence de ce qui avait eut lieu, de faire protester par le gouverneur de Malacca, contre la prise de possession de Singapore, et de protester moi-même à la tête de mon conseil et de la manière la plus forte contre cet acte illégal." 49

De Nederlandsche geschiedschrijver kan niet anders dan bij dit alles het hoofd schudden. Onze onderhandelaars te Londen zullen ten slotte nog bederven, wat er verder nog te bederven viel, deels ook door kleinmoedigheid, deels door averechtsch inzicht. Trouwens reeds bijna eene halve eeuw geleden werd ons beleid in deze ten scherpste veroordeeld door een man, wiens schrifturen anders de zachtheid zelve zijn en die nog slechts op betrekkelijk onvolledige gegevens zijne ongunstige meening kon vestigen; ik bedoel den heer D. C. Steyn Parvé. Op bl. 50-51 zijner Handelingen van Sir James Brooke op Borneo van 1859 leest men namelijk over Singapore's stichting het volgende:

"De twisten, protesten en briefwisselingen, waartoe deze inbezitneming aanleiding gaf, zijn zoo dikwijls en zoo omstandig door anderen omschreven, dat wij daarbij niet zullen behoeven stil te staan. Genoeg zij het, hier aan te merken, dat wellicht geene aangelegenheid de onverschilligheid, kleinmoedigheid en het gebrek aan geestkracht van onze vroegere diplomatie meer heeft doen uitkomen dan deze zou hoogst gewichtige gebeurtenis. Ware er dadelijk met kracht gehandeld geworden, dan lijdt het geen twijfel, of de Nederlandsche vlag zou spoedig weder de Engelsche kleuren op Singapore hebben vervangen.

"De houding der beide gouvernementen in deze verwikkeling laat zich in weinige woorden beschrijven. Terwijl het Engelsche bestuur in Indië handelde en doortastende maatregelen nam, deed het Nederlandsche niets anders dan vertoogen schrijven. Hoe onzeker de Engelsche overheden zelven waren omtrent de rechtmatigheid van hunnen titel op Singapore, en hoezeer zij zelven verwachtten, dat hunne aanmatiging zou moeten wijken voor de billijke anspraken en de rechtmatige tegenkanting der Nederlanders, blijkt genoeg uit deze omstandigheid, dat het definitief tractaat, waarbij Singapore door den sultan van Djohor bepaald aan de Engelsche compagnie afgestaan werd eerst den $2^{\text {n }}$ Augustus 1824, gesloten, en den $9^{n}$ November 1824 door den gouverneur-generaal geratificeerd werd, en dus niet dan nadat reeds bij het tractaat van Londen door het Nederlandsche bestuur was 


\section{afgezien van alle vertoogen tegen de inbezitneming van Singapore."}

If you can be sound!

\section{V.}

Bij brief dd. 25 Februari 1819 richtte onze Landvoogd zijn eerste betoog over het wederrechtelijke der Singapoorsche vestiging aan het Bengaalsch bestuur ${ }^{50}$; het was onvolledig doordien de gouverneur Timmerman Thyssen geene genoegzame gegevens had verstrekt, waarvan de Regeering hem, naar wij weten, terecht of te onrecht eene ernstige grief makte. Nochtans had dit hier eene lichtzijde. Lord Moira, bovendien op een dwaalspoor gebracht door Raffles' leugenachtige voorstellingen - deze had zelfs bij de vertaling van het tusschen ons en Djohor gesloten contract geknoeid! 51 - achtte zich op ontvangst van het niet afdoend $\mathrm{Ba}$ taviaasch betoog zóó sterk, dat de belofte van ontruiming werd gegeven zoo er inderdaad eene wederrechtelijke bezetting had plaats gevonden. Uit dien hoofde was het uit Calcutta ontvangen antwoord dd. 26 Juni 1819 hoogst belangrijk. ${ }^{52}$ Daarin werd op den voorgrond gesteld, dat Raffles in ieder geval zijne instructiën overschreden had, dat voor den Gouv.-Gen. in Rade dientengevolge de bezetting van Singapore "een bron van ongeveinsd verdriet was" ( $(12)$, ja erkend werd het gemeene van Raffles' handeling ( $(17)$; doch nu het feit eenmaal was voldongen, kon men niet meer terug, tenzij inderdaad Nederlands rechten afdoende bleken: dan echter ook zou men "onmiddellijk" terugtrekken $(\S 19)$; dan zou men "zonder aarzeling" tot het opbreken van den post last geven $(\$ 45)$; en evenzeer zou "onverwijld" het eiland worden verlaten, indien het bleek, dat het gebied van een onafhankelijk vorst was geschonden en deze er zich over beklaagde $(\S 46)$.

Dit antwoord was te Batavia nog niet ontvangen, toen onze Regeering vollediger berichten van Malakka erlangde, hetgeen den Gouv.-Gen. onverwijld een nader, uitvoerig betoog dd. 25 Maart 1819 naar Bengalen deed schrijuen. ${ }^{53}$

Doch ook dit stuk scheen, blijkens het uit Calcutta ontvangen antwoord dd. 21 Augustus 1819, nog niet in allen deele voldoende. Terwijl lord Moira in een schrijven dd. 31 Juli 1819 aan Raffles zijne voldoening deed betuigen over de blijkens bl. $42 \mathrm{l}$ 
ontvangen gunstige berichten betrekkelijk Singapore's bloei, doch hem tevens berispte, wegens zijne verdere intriges tegen het Nederlandsch gezag ${ }^{54}$, herhaalde het Bengaalsch bestuur, in zijn antwoord aan Batavia, dat de bezetting zou opgebroken worden, indien het ons mogelijk bleek de leemte in Batavia's tweede betoog weg te nemen. Blijkbaar geloofde men niet ten volle dat ons bestuur hiertoe in staat zou zijn; zoo sprak de Britsche landvoogd in Rade zich nog verder vast. 55

De directie der Oost-Indische Compagnie te Londen erkende bij de aan zijn Landvoogd gerichte missive dd. 25 Januari 1820 zijne groote ingenomenheid met het toen juist ontvangen afschriftschrijven dd. 26 Juni 1819 van de Bengaalsche regeering aan den Gouv.-Gen. Van der Capellen; en met warme belangstelling zeide het af te wachten het bescheid van het Nederlandsch-Indisch bestuur, waartoe lord Moira i. R. dit in goed vertrouwen op de overwinning had uitgenoodigd, uitgedaagd zoude ik zeggen, wanneer niet de toon der brieven zoo voorkomend mogelijk ware geweest ${ }^{56}$.

Het zoo zeer verwachte antwoord uit Batavia kwam bij missive dd. 16 December $1819 \ldots$ maar viel lang niet aan de heeren te Calcutta mede. Tegenspraak had uit den aard der zaak onze Regeering in de gelegenheid gesteld de verschillende punten der quaestie scherper, meer afdoende te formuleeren. Inderdaad, na de reeds gegeven betoogen, was het al te overtuigend, dat Raffles ten onzen aanzien het recht met voeten had getreden ${ }^{57}$. Elout, in Nederland van het stuk kennis nemende, noemde het naar waarheid: "een brief, die allen lof verdient en met juistheid, kracht en klaarheid gesteld is" 58. En minister Canning zelf vond na lezing van dat meest gewichtige sluk, hetwelk "onze aanspraak boven redelijke bedenking" stelde, gelijk hij zich vrijmoedig tegenover onze gevolmachtigden nitdrukten 59, de zaak uit een wettelijk oogpunt zóó hopeloos, dat hij geen ander middel tot redding wist, dan ... de destijds te Londen aangevangen onderhandelingen af te breken, en door de zaak op haar beloop te laten, de Nederlandsche diplomatie in hare kleinmoedigheid door wachten nog verder te demoraliseeren.

Onze landvoogd, ik merkte het reeds op, maakte zich van den indruk, dien zijne papieren op het Bengaalsch bestuur zouden uitoefenen, geene overdreven illusiën; nu reeds nagenoeg de zekerheid hebbende, dat de meest overtuigende bewijzen Calcutta niet zouden bewegen den buit prijs te geven, waarop Raffles 
nu eenmaal zich, tegen den eigen wil van lord Moirra en zijn Raad in! had geworpen. Van der Capellen gaf die donkere vermoedens te kennen in zijn rapport dd. 9 November 1819, waarbij hij het Bengaalsche schrijven van 21 Augustus te voren naar Den Haag zond ${ }^{60}$; hij herhaalde ze in de depêche dd. 16 December 1819, waarbij hij afschrift van zijn naar Calcutta gezonden schrijven van dien datum het Ministerie aanbood ${ }^{61}$. Met dat al bleef hij zijn vertrouwen vestigen op het rechtvaardiger en meer onbevangen oordeel van het bestuur te Londen; doch, waar men zich wendde of keerde, overal was het slechts diefjes, met diefjes maat. Wèl schreef men van daar aan Bengalen, dat de onhebbelijke wijze betreurd werd, waarop Raffles weder was te werk gegaan; de zaak zelve begon men echter zeer fraai te vinden, waarom Directeuren den Gouv.-Gen. in Rade in de $\S \S 13 \mathrm{vv}$. hunner missive dd. 8 Augustus 1820 een zachten wenk gaven, over de onvoorzichtigheid der belofte om Singapore te verlaten, wanneer het wederrechtelijke der bezetting aan den dag trad 62 !

De Londensche directeuren kenden echter niet voldoende hun Landvoogd als vain, weak and honest, wanneer zij een oogenblik mochten gevreesd hebben, dat lord Moira zich door eene dergelijke voorwaardelijke belofte gebonden zoude achten; immers niets belette ten slotte, dat het meest overtuigende, toch niet als overtuigend werd aangenomen. Dat dit de weg zou zijn, gaf lord Moira zelf aan baron Van der Capellen particulier te kennen, nog vóór men te Calcutta den brief van 16 December 1819 kon ontvangen hebben. Toen namelijk de Calcuttasche missive van 21 Augustus 1819 naar Batavia werd gezonden, had de Britsche landvoogd het voornemen opgevat ook den Gouv.-Gen. Van der Capellen particulier en vertrouwelijk te schrijven. Ziekte belette hem dit echter, ten minste dit verhaalt lord Moira, en dientengevolge kwam hij er eerst toe bij brief dd. 14 Januari 1820. Evenals in de officieele correspondentie verdedigde hij het gebeurde met ons streven om, door allerwegen ons in den Archipel neder te zetten, een handelsmonopolie ten koste van Engelands belangen in den Archipel te vestigen. Hij erkende, dat die zucht om aldus GrootBritannië te benadeelen, niet de bedoeling van Van der Capellen persoonlijk was geweest, doch slechts van Elout; ook wilde hij wel aannemen, dat deze evenmin daarmede had beoogd oneenigheid tusschen de twee bevriende ratiën te zaaien, dat dit enkel was voortgevloeid: "from an ungovernable splenatic distaste towards the 
English" ; het resultaat was echter hetzelfde geweest; dientengevolge had het Britsch-Indisch bestuur...- hoezeer werd Fagel's vrees in zijn sub 34 wedergegeven brief tot werkelijkheid! - voorzorgsmaatregelen willen nemen ou dit te neutraliseeren, maatregelen echter, die geenszins de bedoeling hadden om onze Regeering te kwetsen. Het moest uitsluitend aan Raffles worden geweten, verontschuldigde zich lord Moira, dat het Nederlandsch-Indisch bestuur reden tot klagen was gegeven; de luitenant-gouverneur had daarvoor eene berisping ontvangen, gelijk hij die ook vroeger had bekomen wegens zijn "unjudicious zeal" op Sumatra. Maar wijl Raffles vroeger door het bestuur in Engeland was gehandhaafd, niettegenstaande het ongunstig oordeel van het Calcuttaasch bestuur over den gewezen Luitenant-Gouverneur van Java, wenschte dit niet langer tegen de betere meening van Londen te reageeren. Zoo had hij hem, ten gevolge van onze anti-Engelsche houding opgedragen eene havenplaats in de Oostersche wateren te zoeken, waar de Nederlandsche regeering geene aanspraken zou kunnen gelden. Raffles, erkende de Landvoogd, overschreed hier weder zijne zending, maar... nain, weak and honest!

But the establishment could not be withdrawn, without our acknowledgment of a right in your Government, which I regard as incapable of being asserted otherwise than as unjuriously to us.

Tegenover zulk een vooropgezet plan, dat alleen door een onmiddellijk militair optreden ten onderste boven geworpen had kunnen worden, moest onze papierbatterij wel machteloos blijken. Ook Van der Capellen's waardig particulier vertrouwelijk antwoord dd. 16 April 1820, waarin hij voor Elout partij trok en nader betoogde, dat slechts Raffles door zijne leugentaal de Britsche bewindslieden op een dwaalspoor had gebracht, kon natuurlijk den staat van zaken niet meer doen veranderen ${ }^{63}$.

Maar wat was dan het lot van ons afdoend officieel betoog dd. 16 December 1819? - Er niets meer op kunnende antwoorden, ontsloeg het Britsch-Indisch bestuur zich van eene wederlegging, door bij briefje dd. 22 April 1820 naar de destijds te Londen aangevangen onderhandelingen te verwijzen, een door zijne kortheid hinderlijk schrijven ${ }^{64}$. En eerst dd. 17 Juni 1820 gaf lord Moira van deze laatste correspondentie kennis aan de directie te Londen, niettegenstaande brieven, na April 1820 geschreven, reeds lang vòò dien tijd derwaarts waren gezonden, en terwijl de Engel- 
sche regeering, die de onderhandelingen zeide geschorst te hebben in afwachting van eenige toelichting op het Nederlandsch schrijven van 16 December 1819, als het ware dagelijks, volgens haar beweren aan ons, naar de Calcuttasche correspondentie uitzag! Lord Moira gaf bovendien slechts in zịjne depêche naar Londen van 17 Juni 1820 te kennen, dat hij zoo kort had geantwoord, omdat, in weerwil der innerlijke waarde van Engelands aanspraken (§11)! het toch vergeefsche moeite zou zijn oın ons met bewijzen te overtuigen; hij sprak daarbij het vertrouwen uit (\$22), dat de in het moederland aangevangen onderhandelingen strekken zouden om Engelands rechten en belangen te waarborgen 65 ... Dat was geworden vau de door lord Moira zelf als gemeen veroordeelde daad... Vain, weak and-honest?

En voor ons, die gelegenheid hadden nu achter de schermen te zien, makt de zaak een te droeviger indruk, als wij lezen hoe van Engelsche zijde in den boezem zelf der eigen Indische besturen er over gedacht werd.

In dezelfde maand Augustus 1819, dat lord Moira i. R. aan Batavia trachtte te bewijzen, dat onze aanspraken zwak waren, had zich het bestuur te Poeloe Pinang andermaal ter neder gezet om Calcutta aan te toonen, dat wezenlijk de nederzetting niet was te verdedigen. De anleiding tot dit schrijven was gelegen geweest in de op bl. 4.21 vermelde berisping, die gouverneur Bannerman en zijn raad over hun gemis aan medewerking met het bestuur te Singapore, hadden gekregen. Toen dit stuk Pinang bereikte, was Bannerman overleden, doch dit belette niet, dat het bestuur van Prince of Wales dd. 26 Augustus 1819 andermaal het gepleegde onrecht bij wijze van verdediging tegen de ontvangen vermaning onder de aandacht der Bengaalsche regeering bracht. ${ }^{6} 6$ Die brief was dus te Calcutta ontvangen, toen lord Moira, ofschoon beter wetende, tegenover Van der Capellen, particulier en officieel, zoomede tegenover Londen, het goed recht op Singapore staande hield. Maar een lid van den Calcuttaschen raad schijnt toch deze manier van handelen wel wat al te sterk te hebben gevonden. Dezelfde mannen namelijk, die de depêche naar Londen van 17 Juni 1820 hadden onderschreven, te weten lord Moira, James Stuart, John Adam en John Fendall, kwamen den $1^{n}$ Juli d.a. v. weder bij elkander en daar werd voorgelezen een hoogst opmerkelijk concept, door Stuart den 22n Juni geteekend; het stuk behoort tot de verzameling "Minutes" van het India Office, op het gewicht waarvan Bisschop terecht in het verslag van zijn 
onderzoek heeft gewezen (men zie bl. 188 dl. XLII dezer Bijdragen). Stuart stelde op den voorgrond, dat het dan toch noodig was om het bestuur te Londen volledig in te lichten. Hij erkende, dat Wolterbeek's contract met Riouw van volle kracht en waarde was, tegenover de geheele wereld, staat er, en dat Van der Capellen's brief dd. 16 December 1819 zoo goed als zeker de onderhoorigheid van Singapore aan Riouw en dus aan het Nederlandsch gezag uitmaakte! Tegenover het geschetter der jingo's — van Raffles tot Boulger toe, alsof het Nederlandsch-Indisch gouvernement verschrikkelijkheden pleegde door de hand te leggen op Oost-Indische plaatsen, die geschikt voorkwamen, - sprak hij het éénige juiste antwoord uit, dat het te gek was om alleen te loopen, dat men ons een recht zou betwisten, hetwelk iedere onafhankelijke Europeesche natie, ook Engeland, geregeld in toepassing bracht; en hij verklaarde ten slotte geene andere oplossing te kunnen aanbevelen, dan het Engelsche gouvernement in overweging te geven, om de onderhandelingen in die richting te leiden, dat Nederland afzag van - Riouw en Engeland prijs gaf Singapore, waardoor beide partijen, ook op het punt van eer, zich tevreden gesteld konden achten en de Nederlanders bevrijd zouden zijn: "from a galling rival establisment upon the skirts of their chief settlements". ${ }^{67}$

Wij zien uit dit opmerkelijke en waardige stuk hoe krachtig wij met zulke vrienden in het Britsch-Indisch hoofdbestuur waren, ook al heeft de Bengaalsche regeering zich er niet mede vereenigd, immers enkel wegens den stand der zaak, waarin zij zich toen reeds bevond. Nooit, nooit misschien zijn de fatale gevolgen van nationale flauwhartigheid sterker aan den dag getreden dan in deze treurige geschiedenis. Wees gerust, schreef eenige jaren later, namelijk in Jamuari 1840 , een Russisch diplomaat uit Londen naar Petersburg, over Engelands boosheid wegens het voortdringen der Russen in Khiva, onder generaal Perooski. "Wees gerust, indien Perooski zijn werk naar den eisch volbrengt, laat hij den Khan dan afzetten of ophangen of den knoet geven, en niemand zal zich met ons bemoeien. Maar geef ons in 's hemels naam feiten en geen diplomatieke nota's. Zij hebben niet de minste waarde in Europa, en nog minder in Azië". 68

Merkwaardige slotsom, waartoe wij met al onze bedaardheid, beradenheid, koelheid, ten slotte evenzeer zijn moeten komen. Niettemin nòg zou, en wel te Londen, ons een oogenblik de gelegenheid worden aangeboden, om wellicht de zaak andermaal in 
het spoor te brengen, waardoor onze nationale eer zou worden gered; maar was ons Indisch bestuur om niets kleinmoedig geweest te Batavia tegenover Engeland, nu waren onze vertegenwoordigers hooghartig, evenzeer zonder reden, te Londen, niet ter bevrediging van een te hoog gestemd nationaliteitsgevoel, maar van nietswaardigen hoogheidszin voor het gezag van... het Plein tegenover Batavia! If you can be sound?

VI.

De besprekingen over de herziening van het tractaat van 13 Augustus 1814 waren te Londen medio Juli 1820 aangevangen tusschen Fagel met Elout aan onze zijde, Canning met Castlereagh van Engelands kant. Reeds vóór men nog aan eene Singaporequaestie dacht, was door de Nederlandsche regeering het verlangen naar onderhandelingen voor het uitmaken van allerlei geschillen kenbaar gemaakt; van Engelsche zijde toonde men er niet veel ooren naar te hebben, totdat het nieuwe geschil over Singapore de Britsche regeering zelve eene conferentie wenschelijk deed verklaren; maar toen ook werd Singapore het punt bij uitnemendheid.

Art. 8 der door den Koning aan onze gemachtigden gegeven instructie luidde als volgt:

Zoodra en zoo dikwijls zich maar eenigermate de gelegenheid aan zal bieden, zal Onzentwege het leedwezen en de bevreemding worden te kennen gegeven, die het in bezitnemen van Singapore hier te lande heeft veroorzaakt, met aanmerking dat Ons, ten tijde der beantwoording der meergemelde nota van lord Clancarty (Augustus 18I9), de omstandigheden van dien vermetelen en door niets te verontschuldigen aanslag op de rechten van Nederland en van deszelfs bondgenooten slechts onvolledig bekend waren ${ }^{69}$. Onze Gevolmachtigden zullen zorg dragen van die rechten met de meeste uitvoerigheid te betoogen en te ontwikkelen, daarbij speciaal acht gevende op hetgeen ten zelfden einde door den baron Van der Capellen aan den Gouverneur-Generaal in Bengalen is gemeld. Wij dragen hun uitdrukkelijk op aan de goede trouw hunner Medeonderhandelaars de vraag ter beslissing voor te stellen of Nederland behoudens deszelfs eerbied voor de tractaten en het daarvan afhankelijk crediet bij de Inlandsche vorsten en volken, in het alzoo gebeurde kan berusten, en Wij verlangen dat zij vervolgens met al dien ernst welke het gewicht der zake medebrengt op de ontruiming van Singapore en op de herstelling van dit eiland in deszelfs vorigen toestand aandringen; als zijnde deze maatregel de eenige 
door welken de nadeelige indrukken worden weggenomen, die tegen alle recht en reden en zonder een schijn zelfs van eenig aannemelijk voorwendsel bij de naburen en in den geheelen Archipel is te weeg gebracht. 70

Reeds op de eerste bijeenkomst der onderhandelaars dd. 20 Juli 1820 (van Engelsche zijde werd er alleen voorloopig door Canning aan deelgenomen) vonden onze gemachtigden gelegenheid aan deze opdracht gevolg te geven, doordien Canning op het behouden van Singapore aandrong. Onzerzijds werden alle de daarmede verband hebbende omstandigheden naar waarheid opengelegd, en de onmogelijkheid aangetoond, waarin het Nederlandsch Gouvernement zich bevond om in de aanhouding dier bezitting toe te stemmen, daar het te dezen aankwam niet zoo zeer op het recht van Nederland of Groot-Britannië, maar op dat van den sultan van Linga, enz., aan wien Nederland van alle tijden zijne vriendschap en bescherming verleend had, en die de oude verbonden van vriendschap had vernieuwd, met uitzondering alleen dat daarbij nu het beginsel van vrijen handel was aangenomen; het Nederlandsch Gouvernement kon er dus niet in toestemmen, dat deze Vorst van een gedeelte zijner domeinen zoude verstoken worden, en dat wel op grond (gelijk de heer Raffles had uitgedacht), dat niet Z. H. maar een ander de ware vorst van Linga zijn zoude, welk voorwendsel eindelijk tot noodzakelijk gevolg zou moeten hebben, dat de door ons erkende en nooit betwiste vorst, met wien de Britsche ambtenaren zelven verdragen gesloten en over den afstand van Singapore gehandeld hadden, zelfs geen zekerheid nopens zijne andere bezittingen had.

"Wij mogen met eenig vertrouwen zeggen", rapporteerden onze gemachtigden den volgenden dag naar den Minister van Buitenlandsche Zaken, "dat al wat wij te dezen aanvoerden op den Britschen gevolmachtigde eenigen indruk maakte". Doch reeds aanstonds gaf Cauning bedektelijk te kennen, dat de quaestie niet meer uitsluitend naar hare innerlijke waarde kon worden afgedaan. Hij mocht namelijk niet ontveinzen, zeide hij, "dat deze geheele zaak in de opinie van het Britsch publiek eenig gewicht verkregen had, hetgeen de zaak van een bijzonderen aard had doen worden." Ook deelde hij mede, dat het Gouvernement van Bengalen in zijne laatste brieven het onderwerp nogal uit een ander oogpunt had voorgedragen. - Onze gemachtigden beantwoordden deze zwarigheden met nadere ophelderingen, en voegden daarbij, 
dat ook het Nederlandsch publiek over al het gebeurde in de Indische zeeën een aandachtig oog geslagen had; zij deden voorts opmerken, van hoe weinig belang Singapore voor de Britsche belangen in Indië was, en zij ontwikkelden eindelijk den geest van vrijheid, die in de Nederlandsch-Indische regeering allerwegen doorstraalde; zij deden zien, dat Nederland geene andere plaatsen bezet had dan die te voren bezeten waren geweest; dat er alleen dit merkbaar onderscheid bestond tusschen de vroegere en tegenwoordige bezittingen, dat toen alles uitsluiting ademde, gelijk dit het systeem was van alle andere volken en zelfs nog was, terwijl Nederland het voorbeeld gaf van de opening van vrijen handel, zoodat alle vrees en ongerustheid in waarheid als ijdel moesten worden beschouwd.

De vergadering van 20 Juli 1820 ging uit elkander onder afspraak, dat Cauning een ontwerp van overeenkomst zou opmaken, hetwelk tot grondslag voor nadere behandeling kon dienen.

Canning gaf hieraan bij brief van 22 Juli gevolg. Art. 4 er van luidde aldus :

The island of Billiton having been ceded to the British Government expressly and by name together with the island of Banca «and their dependencies» in the year 1812 , and not having been ceded to the Netherlands Government by the convention of I3 August 18I4, by which Banca was exchanged against Cochin, the British Government claim the island of Billiton as their undoubted territory. But the British Government nevertheless will consent to transfer the island of Billiton to the Netherlands Government, provided that the Netherlands Government will engage not to interpose any obstacle to the establishment of a British factory at Singapore.

Natuurlijk, dat onze gemachtigden hierin niet wilden treden; in de conferentie dd. 24. Juli boden zij een tegen-ontwerp aan, waarvan de beide eerste artikelen aldus luidden:

I. Le Gouvernement de la Grande Bretagne désavoue la conduite tenue par Ses agens dans les différentes parties de l'Archipel indien, et reconnait les droits du Gouvernement des Pays-Bas sur les places et établissements réoccupés par celui-ci en vertu et en conséquence du traité conclu le I3 Août I8I4, nommément sur ceux qui ont donné lieu à des altercations connues. Le Gouvernement Britannique s'engage à donner les ordres nécessaires pour l'évacuation de Singa-Poora.

2. Pour terminer le différend survenu par rapport à Billiton, le Gouvernement Britannique cède le dit îlot au Gouvernement des Pays- 
Bas, qui en échange cède au premier la place de Fultha située au continent des Indes.

Den $26^{\mathrm{n}}$ Juli kwam men andermaal bijeen. Inziende, dat men het over Singapore niet eens kon worden, gaf Canning te kennen, dat er eene zwarigheid bestond om die quaestie af te doen, voordat nadere berichten van den Gouverneur-Generaal van Britsch-Indië waren gekomen; en dat dientengevolge tot zoolang de verdere onderhandelingen zouden dienen te worden uitgesteld, tenzij men konde overeenkomen in een voorwaardelijk artikel waarover hij zijne aedachten zou laten gaan.

Hierna scheidde men; ten zelfde dage ontvingen onze gemachtigden een ontwerp-artikel, waarbij Canning de volgende vreemdsoortige uitlating voegde, doch die overigens wees op den vertrouwelijken toon, die tusschen onze gemachtigden en den zich teekenenden "Very sincerely Yours Canning" bestond:

This is the very utmost that we could do, under present circumstances. It gives you, as you see, all that you can want, if you can be sound.

And this we cannot do unless it is most liberally compensated on your part.

Het ontwerp luidde aldus:

Whereas a British establishment has been formed upon the island of Singapore, in virtue of a treaty concluded on the $6^{\text {th }}$ of February I819, between an agent of the British Government on the one part, and Hussein Mohammed Sjah, assuming to be the rightfull Sovereign of the kingdom of Johore, and Datoo Toemenggoeng Sree Maharajah Abdul Rahman, assuming to be the rightful chief of Singapore, on the other part; and whereas it is alleged by the Netherlands Government of Batavia, that the said island of Singapore is a dependency upon Malacca, and that neither Hussein Mohammed Sjah, nor Datoe Toemenggoeng Sree Maharajah Abdul Rahman has any lawful power to convey to the British Government the right of forming an establishment at Singapore; and whereas the Governor-General of BritishIndia has, in consequence of a representation to the effect above stated from the Netherlands Government of Batavia, instituted an enquiry into the truth of these allegations: the British Government engage to give instructions to the Governor-General in Council of Bengal, that in case it shall be ascertained that these allegations are true, the British troops and establishment shall be withdrawn from the said island of Singapore.

It is agreed by the Netherlands Government that in such case the 
treaty concluded on the Igth of Augustus 1818 , in the name of the British Government with Sultan Abdul Rahman, whom the Netherlands Government represent as the lawful Sovereign of the Kingdom of Johore, shall be acknowledged and respected by the Netherlands Government in so far as it stipulates for the admission of British trade and navigation into the ports subject to the said Sultan, on the footing of the most favored nation.

It is understand also that the Dutch agree, in such case, not to erect fortifications on the island of Singapore.

Gevonden! Gevonden! Gevonden! zouden onze gevolmachtigden, in den staat, waarin de quaestie nu eenmaal verkeerde, bij het lezen van het door mị onderstreepte blijmoedig hebben mogen uitroepen, dacht $\mathrm{ik}$..... if you can be sound, was de vriendschappelijke vermaning geweest. Maar in plaats van met vier handen toe te grijpen, om slechts over den vorm van een gezamenlijk ouderzoek te contracteeren, en daarna desnoods den afdoenden brief van Van der Capellen dd. 16 December 1819 over te leggen, is meñ onzerzijds een anderen weg opgegaan.

Den 27n Juli had de bijeenkomst over het voorstel plaats en daar verwierpen onze gemachtigden het: vooreerst wegens - ik geef de eigen woorden van het verbaal weder, daar men het anders wellicht niet zou kunnen gelooven: "het weinig welvoegelijke van eene verwijzing ter beslissing aan de onderhoorige Regeeringen, de Nederlandsche gevolmachtigden moesten doen huiverig zijn in het aannemen van het laatst gedaan voorstel"; en ten tweede, omdat eigenlijk zulk een onderzoek niet meer noodig was, daar Van der Capellen's brief dd. 16 December 1819 , die nu verd voorgelezen, Nederlands recht boven bedenking stelde.

Onze gemachtigden moeten wèl doordrongen zijn geweest van den schoonen rol, dien zij hier vervulden, toen zij aldus de hoogheid van het Plein op den voorgrond stelden; doch zeker zullen zij niet de overtuiging hebben gehad, dat Canning nooit het voorstel zou hebben gedaan; indien hij de argumenten van 16 December 1819 te voren gekend had! Het waren onze gemachtigden, die voor hem aanstonds weder de zaak in het reine brachten, door tegelijkertijd zijn voorstel te verwerpen en hem met den inhoud van den brief bekend te maken. Het werd toen slechts eene zaak van beleid voor de Britsche gemachtigden om zoo goed mogelijk terug te krabbelen, en dat vond weldra met den meesten spoed plaats, om eerst na jaren er in toe te stemmen elkander terug te zien! 
Niet zonder eenigen weemoed, lees ik in het rapport onzer gemachtigden dd. 28 Juli 1820 an het Ministerie van Buitenlandsche Zaken:

"Wij waren beiden zonder lang beraad van gevoelen, dat het voor ons onmogelijk was dit voorstel aan te nemen. Het was toch niet het Bataviasche Gouvernement, dat de ten dezen geopperde gedachten omtrent Nederlands recht voedde; het was Z. M. zelve die daarvan overtuigd was, die geen meer inlichtingen noodig had; de zaak was (als wij ons zoo mogen uitdrukken) dus voor ons voldongen, en wij mochten uit dien hoofde zoo min als uit aanmerking van het onvoeglijke eener zoodanige handeling, toetreden tot een bepaling bij welke de souvereinen in Europa eene zaak lieten afhangen van de beslissing hunner onderhoorige regeeringen in Indië, bij welke vooral Z. M. onze Koning zijn onbetwistbaar recht en dat zijner bondgenooten in Indië, aan zulk een nader onderzoek en beslissing onderwierp."

Canning kennis nemende van de door onze gemachtigden voorgelezen stukken, zeide thans, dat hieruit inderdaad bleek dat ons recht boven redelijken twijfel was. Doch hij beaamde nu tevens de onzerzijds geopperde zwarigheden, waardoor hem de meest geschikte gelegenheid werd gegeven om op zijn voorstel terug te komen. Van eene aanneming van dit artikel om alsdan over de andere quaestiën de samenkomsten voort te zetten, was alzoo geene quaestie meer. Hij volhardde overigens natuurlijk in zijn gevoelen, nopens de onmogelijkheid om vóór het ontvangen van de meening van den Britschen Gouverneur-Generaal over Van der Capellen's brief, het geschilpunt stellig af te doen. Hij verzocht, dat alsnog zoude worden beproefd eenig verbeterd voorwaardelijk artikel te ontwerpen, en dat inmiddels de brief van 16 December 1819 met bijlagen hem mocht worden gelaten, ten einde daarvan afschrift te doen maken, waarin bewilligd werd. - In den namiddag van den $27^{\mathrm{n}}$ zond Canning nog eene in vele opzichten zeer geschikte ontwerp-overeenkomst, waarvan art. 4 het bovenvermelde Singapore-artikel inhield.

Ziehier wat verder over deze behandeling door onze gemachtigden in hun rapport dd. 28 Juli naar Den Haag werd bericht:

"Gisteren hierover bepaaldelijk zullende handelen, lazen wij den Britschen gevolmachtigde voor den brief, dien de GouverneurGeneraal Van der Capellen op den 16 December $(a)$ aan den

(a) Er staat op 'bl. 128 van Elout's Bijdragen 19 December; doch deze foutieve datum komt ook voor in het aan het Ministerie geschreven rapport. 
Gouverneur-Generaal van Britsch-Indië had geschreven, en welks verstandige, beredeneerde en krachtige inhoud, gestaafd door bijgevoegde stukken, ons voorkwam dat indruk moest maken. Wij hebben dan ook ons niet bedrogen: na de lezing merkten wij aan $(a)$, dat wij geen beter antwoord op het gedaan voorstel konden geven dan waartoe die brief zelve aanleiding gaf. - Het wederantwoord was voor ons wel niet voldoende, maar wij moeten recht doen aan de openhartige wijze waarop de heer Canning ons te kennen gaf, dat naar zijn persoonlijk gevoelen, de stukken hem nu bekend gemaakt, onze aanspraak boven redelijke bedenking stelden, maar hij bracht tevens bij de onmogelijkheid, dat het Britsch Gouvernement hier die zaak zoude afdoen, zonder ook op de laatste strukken het gevoelen van den Britschen Gouverneur-Generaal te vernemen, hetwelk naar de gewone berekening niet langer dan een paar maanden kon uitblijven. Hij dacht dat een tegengesteld gedrag dien hoogen ambtenaar wellicht in onaangenaamheden zoude kunnen wikkelen. De heer Canning trad in bijzonderheden, tot welker mededeeling aan ons hij zekerlijk niet gehouden was; hij besloot dus met het gevoelen, dat òf de conferentiën moesten worden uitgesteld totdat nadere berichten uit Britsch-Indië zouden ontvangen zijn, òf wel dat het door hem voorgeslagen of eenig ander verbeterd en van de bestaande zwarigheid gezuiverd artikel in de onereenkomst zoude worden gelascht; hij verzocht ons daaromtrent onze gedachten te laten gaan. Wij konden dit niet afslaan, maar wij ontveinsden hem niet, dat wij daartoe weinig kans zagen, en ook nu nog is dit ons hoogst moeielijk voorgekomen. Het kan ons niet dan aangenaam zijn hieromtrent eenige wenken te ontvangen. De noodzakelijkheid eener afdoening van zaken, de waarschijnlijkheid dat de Britsche Gouverneur-Generaal overtuigd zal wezen, staan aan de eene; de mogelijkheid van het tegendeel en het zonderlinge van zulk eene voorwaardelijke overeenkomst, staan aan de andere zijde."

Het luidt bijna naïef om hier te gewagen van den gelukkigen indruk, dien Van der Capellen's brief op den Britschen gemachtigde had gemakt! Hij ging naar huis er mede en ... kwam terug met het vaste voornemen om van het door mij cursief aangegeven alternatief niets meer te willen weten!

In de bijeenkomst van den $28^{\text {n }}$ Juli gaf Canning den brief van 16 December terug onder mededeeling, dat èn de betrekking van Singapore

(a) merkten wij aan, staat in het rapport. 
tot het rijk van Djohor, èn de wettige aanspraak van den thans regeerenden sultan van Riouw, enz. tot de souvereiniteit, hem bewezen toeschenen, voor zoover zulks uit de hem medegedeelde stukken viel te beoordeelen; alleen vroeg hij, of niet de verklaring van den Gouverneur van Malakka, Couperus, indertijd het recht van Nederland verzwakt had. - Het een en ander werd daarna het onderwerp van een vertrouwelijk gesprek, in hetwelk alle de omstandigheden werden aangevoerd, die ten betooge van Nederlands rechten strekten. - Opnieuw werd overwogen wat in den onzekeren stand van het geschil over Singapore zoude gedaan kunnen worden tot bespoediging der zak, en werd, onder voorbehoud steeds eener proeve tot het stellen van een voorwaardelijk artikel, het ontwerp van den $27^{\text {n }}$ Juli artikelsgewijze overwogen.

De zaak aldus verknoeid zijnde, kwam men den $29^{\mathrm{n}}$ andermaal ter vergadering, die nu ook bijgewoond werd door Castlereagh. Om later te vermelden redenen, had met onderling goedvinden deze Britsche Minister geen deel aan de beraadslagingen genomen, doch nu het op het einde liep, verscheen hij voor de eerste en laatste maal.

"In aanmerking genomen zijnde", zoo luidt het verbaal, de "zwarigheden, die er bestaan tegen het sluiten eener voorwaardelijke overeenkomst, waarvan in vorige aanteekeningen is melding gemaakt, en door de Britsche Gevolmachtigden verklaard zijnde, dat zij ten aanzien van het verschil over Singapore tot geen bepaald besluit konden komen, voordat zouden zijn ontvangen de berichten van den Gouverneur-Generaal van Britsch-Indië over den laatsten brief van den Nederlandschen Gouverneur-Generaal geschreven op 16 December $1819(a)$ :

"Zoo is besloten de verdere deliberatiën op dat punt vooralsńog aan te houden, doch voorloopig met de behandeling der andere ontworpen artikelen van het dikwijls genoemd ontwerp voort te gaan."

In het rapport dd. 1 Augustus 1828 van Fagel en Elout aan het Ministerie lezen wij o. a. over dit noodlottig uitstel:

"Wij hebben wel alle de redeneeringen bijgebracht, die, getrokken uit de omstandigheden van dien tijd, en uit de ophelderingen, welke de persoonlijke kennis, die de tweede ondergeteekende had, en de berichten van den Gouverneur-Generaal Van der Capellen ons an de hand gaven, naar ons inzien de zaak ten onzen voordeele beslisten; maar hoedanig ook de indruk moge geweest zijn, die dit alles

(a) Op bl. 132 van Elout's Bijdragen abusievelijk gedrukt 1816.

6e Volgr. V. 
op de Britsche gevolgmachtigden gemaakt heeft, hun vast besluit, om niets te beslissen vóór de ontvangst van nadere tijding uit Bengalen, belet de afdoening; en daar wij bij voortduring in een zoogenoemd voorwaardelijk artikel, waarvan wij in onzen vorigen gewaagden, de grootste bedenking zagen, bleef er niets over, dan de verdere behandeling uit te stellen tot nadere anmaning van de Britsche zijde, terwijl men vertrouwde, dat na verloop van een paar maanden de verwacht wordende brieven zouden zijn aangekomen."

En zoo gebeurde het, dat met de samenkomst van den $4^{\text {n }}$ Augustus 1820 de onderhandelingen werden afgebroken. Daar las Canning eene nota voor, waarvan de aanhef aldus luidde:

Their Excellencies the Plenipotentiaries of His Majesty the King of the Netherlands, having communicated to the undersigned Plenipotentiaries on the part of His Britannic Majesty, the copy of a most important despatch relative to the island of Singapore, addressed in the month of December last, by the Baron Van der Capellen, Governor-General of the Netherland possessions in the East, to the Marquess of Hastings, Governor-General of British India, of the contents of which despatch the undersigned had no previous knowledge, - it becomes necessary to wait for the report of lord Hastings upon that despatch, before the conferences between the undersigned and their Excellencies the Plenipotentiaries of His Majesty the King of the Netherlands can be brought to a conclusion.

The undersigned will be prepared to resume those conferences so soon as they shall be in possession of the Governor-General's report, which may be expected in the month of October.

Verder werd nog gewezen op de vruchten der reeds plaats gevonden samenkomsten; terwijl het stuk denzelfden dag door onze gemachtigden, werd beantwoord mede bij nota, die in den aanhef aldus luidde :

Les Soussignés ont eu l'honneur de recevoir la note de LL. EE. lord Castlereagh et Mr. Canning de ce jour, et quoiqu'ils eussent aimé pouvoir terminer dès à présent l'objet de la mission dont ils se trouvent chargés de la part de Sa Majesté le Roi des Pays-Bas, ils se rendent néanmoins à la propositon de LL. EE. Messieurs les Plénipotentiaires Britanniques, de remettre les conférences jusques après la réception des dépêches du Gouvernement Suprême de l'Inde Britannique relatives à l'objet de la lettre écrite le I6 Décembre I8I9, par le Gouverneur-Général baron Van der Capellen à lord Hastings. Ils s'y rendent d'autant plus volontiers, qu'ils osent se flatter, qu'alors la conviction des droits de leur Gouvernement sur le point auquel cette lettre se rapporte, sera établie. 
Zoo makten zich de Britsche gemachtigden van de lastige, onvoorzichtig gedane belofte tot ontruiming van Singapore af door eene waarlijk niet denkbare weigering van onze zijde. Doch ook minister Van Nagell scheen de zaak niet in dezen ongunstigen zin op te vatten. Geenerlei opmerking toch volgde over de mededeeling, dat men Van der Capellen's brief aan Canning had voorgelezen toen het voorwaardelijk artikel nog niet was angenomen; geenerlei gedachte rees ook blijkbaar om per omgaande te antwoorden, dat men onmiddellijk die bepaling behoorde aan te nemen. Den $4^{\mathrm{n}}$ Augustus 1820 schrijft toch Van Nagell uit Den Haag aan de gemachtigden: "De depêche van Uwe Excellentiën van 1 dezer, is gisteren ter hand gekomen: de inhoud zal zekerlijk, simul en semel, met de depêche van $28 \mathrm{Juli}$, een voorwerp van overweging zijn voor mijn ambtgenoot Falck. Er zal, zoo veel mogelijk, spoed gemaakt worden met de slotsom der overwegingen aan Z. M. te onderwerpen, en Hoogstdeszelfs welbehagen te vernemen; doch terwijl men in Engeland twee maanden tijd vraagt voordat men de groote kwestie over Singapore zal kunnen afhandelen, zal men, vertrouw ik, het van onze zijde niet voor onbescheiden houden, dat men de zaken met rijpe rade behandelt."

$\mathrm{Nu}$ tot rijpe rade werd ten slotte tijd, ruim drie jaar! gegeven. Onze telkens terugkeerende aandrang om de onderhandelingen te hervatten, stuitte af op Canning's bepaalden onwil er aan gehoor te geven. Het voorwaardelijk artikel moest al meer tot de geschiedenis gaan behooren; en terwijl dit in de vergetelheid terugzonk, rees Engelsch Singapore met den dag tot grooter luister! Wij, niet zij, hadden slechts nadeel van eene onzekerheid, die ons in de oogen van de inlandsche vorsten en volken vernederde, en onzen handel ondermijnde. Het kwam daarbij Canning ten dienste, dat de Gouv.-Gen. van Bengalen voorloopig Van der Capellen's brief dd. 16 December 1819 niet naar Engeland zond, en dus evenmin het antwoord, waarop de Engelsche gemachtigden zeiden te willen wachten. Waarom die toezending werd nagelaten, kan ik niet raden. Hel ontstemde anders zeer het Londensch bestuur; maar de reden dier ontstemming stelt ten slotte nogmaals in het licht, hoe verkeerd onze geınachtigden hebben gedaan van Van der Capellen's brief over te leggen, zoolang men tot de aangewezen voorwaardelijke overeenkomst niet was gekomen. Gij kunt toch niet begrijpen, luidt in substantie de vermaning, hoezeer men er van Engelsche zijde had kunnen inloopen, wanneer niet 
de Nederlandsche gemachtigden zelven zoo onnoozel waren geweest om het bewuste stuk tijdig over te leggen!! Zoo schreven Directeuren naar Calcutta dd. 27 December 1820 (B):

"Your discussion with the Netherland Government of Java have been the subject of other despatches. We are extremely sorry that the observations, which we have made upon your delay in transmitting documents to us, are applicable to those which have passed upon this important subject, especially the letter from the baron Van der Capellen to lord Hastings on the 16th Dec. 1819, and the reply which we know, through private channel, to have been made to that letter.

"It would be no easy matter to convey to you a correct notion of the awkward embarassment under which His Majesty's plenipotentiaries have been placed by this delay in the pending negociation, and of the advantage it would have given to the Plenipotentiaries of the king of the Netherlands, had they insisted upon availing themselves of it."

En na de ontvangst bij brief dd. 17 Juni 1820 der verwachte stukken werd den Gouv-Gen. het volgend vermanend schrijven, gedagteekend 26 Januari 1822 gezonden (B):

"The details of this communication will be noticed, when we address you again upon the important subject of our relations with the states of the Eastern seas and with the Dutch to which they belong. But we cannot omit this opportunity of observing upon your delay in transmitting to us the correspondence of the 'baron Van der Capellen, whose letter of the 16th of December 1819 (a) you appear to have received on the 21th of April 1820 and to have answered on the next day, but did not take any steps for communicating to us until the 17th of June, although despatches of various dates, from the 23rd of April to the 5th of May, were sent to the Court of Directors by the Manglis, which arrived in England on the 28th of September 1820, and more than three months previously to the Hindostan which brought us the document now in question." 71

Omtrent de oorzaken dezer vertraagde toezending lezen wij niets anders dan het volgende, hetgeen voorkomt in den brief dd. 31 Juli 1823 van het bestuur te Calcutta, alwaar lord Moira was afgetreden, terwijl als waarnemend Gouv.-Gen. fungeerde J. Adam (B):

(a) In B's verzameling staat hier 26 December; dit is blijkbaar eene vergissing. 
"We have to apologise for the inattention, here noticed, but beg to submit, in partial explanation that the delay reprehended by your Hon. Comittee is, in some measure, ascribable to the fact that the packets of several ships, which had put back from stress of weather were sent home on the Hindostan."

Het uitstel der onderhandelingen wegens de Indische correspondentie van 16 December 1819-22 April 1820 kon in den aanvang gemotiveerd heeten, zelfs nog toen de Britsche gevolmachtigden door de onzen op de hoogte werden gesteld van het onbeduidend antwoord uit Bengalen naar Batavia gezonden; want dit antwoord sloot geenszins de mogelijkheid uit, dat de Bengaalsche regeering nader haar gevoelen aan het Londensch bestuur over Van der Capellen's brief zou mededeelen. In werkelijkheid geschiedde dit echter niet, zoodat het wachten wegens deze correspondentie geheel noodeloos is gebleken. Maar ook, toen men wat dit punt betrof, dan toch op de hoogte te Londen was gesteld, bleek het Britsche ministerie niet gezind de onderhandelingen weder op te vatten en terwijl aan het bestuur te Calcutta uitdrukkelijk werd geschreven, om toch vooral niet Singapore los te laten en steeds goed na te gaan en te berichten of wij niet nieuwe aanleiding tot klachten gaven ${ }^{72}$, kwam men ons te Londen tegemoet met een non possumus, dat onzen belangstellenden vorst en zijne regeering met diepe ergernis heeft vervuld.

Stel ik mij voor eerlang deze pogingen om tot eene herziening van het tractaat van 1814 te komen, in bijzonderheden te verhalen, de hier medegedeelde correspondentie kan alvast als eene inleidende bijdrage tot de geschiedenis dier-onderhandelingen beschouwd worden.

Den HaAG

Koningskade 23.

Mèi 1898. 


\title{
A A N TE EK E N I N GEN
}

\author{
BEHOORENDE BIJ HET ARTIKEL
}

\section{„De Singapoorsche Papieroorlog”}

DOOR

\author{
P. H. van der Kemp.
}

Bl. 392 noot 1. Ook is het in Eigen Haard op bl. 16 medegedeelde minder juist, dat lord Hastings, de gouv.-gen. van Bengalen, Raffles, na zijne terugkomst uit Europa, verzocht "thans op te treden als Luitenant-Gouverneur van Benkoelen". In mijne verhandeling over Fendalls en Raffles' opvattingen kan men lezen, dat reeds onder den Gouv.Gen. lord Minto deze zaak in orde was gemaakt.

" 397 noot 2. Dat Fendall een ongunstigen indruk van Elout uit Batavia naar Calcutta had medegebracht, en dit niet zonder invloed op lord Moira was gebleven, blijkt uit sub 130 Opvattingen bl. 463; ov. 123. - Men leze ook mijn artikel "Mr. C. T. Elout als Commissaris-Generaal in Nederlandsch-Indie" in De Tijdspiegel van Juni 1898.

" 397 noot 3 . Opvattingen bl. 353 en 377 ; ov. 13 en 37.

" 397 noot 4. Namelijk bij het volgend schrijven van den Gouv.Gen. dd. 6 Juli 1818 (Bg. 295):

I have the honour to acknowledge your letter, and to offer my congratulations on your safe arrival.

It was painful to me, that I had, in the course of my public duty, to express an opinion unfavourable to certain of your measures in Java. The disapprobation, as you would perceive, affected their prudence alone; on the other hand, no person can have felt more strongly that I did, your anxious and unwearied exertions for ameliorating the condition of the native inhabitants under your sway. The procedure was no less recommended by wisdom than by benevolence; and the results have been highly creditable to the British 
Government. I request you to consider yourself at liberty to carry into execution your wish of visiting Bengal, whensoever your convenience and the state of affairs in the Island may afford an eligible opportunity. The means of rendering the settlement at Bencoolen more advantageous to the Honourable Company than it now appears to be, are certainly more likely to be struck out in oral discussion.

Bl. 397 noot 5. Blijkens het op bl. 294 Bg. aangeteekende :

The Marquis of Hastings had not been very cordial, or even fair, in his exculpation of Raffles on Gillespie's charges; but increased knowledge of the Java administration, and possibly Mr. Fendall's favourable opinion of Raffles's works had modified his views of the latter's ability, and in 1818 Lord Hastings was ready at least to admit that Raffles was an able administator.

" 400 noot 6 . Bij brief (in de Wolterbeek-verzameling) dd. 25 Juli 1818 van den Gouvernementssecretaris te Poeloe Pinang werd namelijk aan het Bestuur te Malakka het volgende geschreven :

The Governor in Council directs me to provide for the possible event of major Farquhar being absent from Malacca at the period of the arrival of the Dutch commissioners ... (a)

In that event the Governor in Council desires, that $\mathrm{Mr}$. Murchison, the acting Resident, shall await the return of major Farquhar from the duty in which he was proceeded and in no account restore the settlements until the Majors return.

M. Murchison will in this event receive the Dutch Commissioners and public authorities with every mark of public distinction and civility, and in the event of an application for the troops to land, the permission is to be granted, and every arrangements made, which may conduce to their comfort and convenience during the short period of delay.

" 401 noot 7. Bijdragen dl. XLIX (1898) bl. 73.

" 401 noot 8 . Het contract van Farquhar, waarvan in mijne verhandeling dikwerf melding wordt gemakt, vindt men o. a. bij Netscher op bl. 252-254.

(a) Er staat verder: „and establishments for the place". De copiist heeft daar iets overgeslagen. Zie verder de noot op bl. 446. 
Farquhar gaf van zijn tocht naar den Riouw-Archipel het volgende verslag dd. 2 September 1818 (B):

We reached Lingen early on the morning of the twelfth after a very expeditious passage of only two days. Having immediately announced my arrival by letter in the evening, I received a reply from His Majesty intimating that he did not himself exercise the functions of Sultan, having vested the political authority of the State with his uncle the Raja Mooda of Rhio and therefore must refer me to him for the settlement of any public business I had to transact $(a)$, I nevertheless resolved to land the following morning for the purpose of having a personal interview with His Majesty and obtaining from him a special letter or authority under his own hand to the Rajah Moodah, in order that I may not experience any difficulties or delay in the final adjustment of the object of my mission after my arrival at Rhio.

Having accordingly made my intentions known to the Sultan at ten o'clock, the following morning several of his boats came on board for my accomodation in which we immediately left the ship, but in consequence of the distance from the shore and the Sultan's residence being situated some miles from the mouth of the river, it was nearly one o'clock before we reached the Palace. On landing we were met by the Prime minister accompanied by the chiefman of the settlement and an immense concourse of people and were escorted to the presence by the Sultan's body guard. We were received by His Majesty at the entrance of the public hall of audience in which the whole of the royal family, nobility and principal chiefs were assembled on the occasion. The audience lasted nearly two hours, when after the delivery of some presents and obtaining a promise from the Sultan that the letter I required should be prepared and sent off to me in the course of the evening, I took my leave and returned on board, directing one of

(a) De brief dd. 11 Augustus 1818 van den Radja luidde namelijk:

"I make known to my friend that I have received his letter by his djurotulis acquainting me with his arrival here from Pontiana. I am extremely glad to have an opportunity of a personal interview with my friend but no matters of buseness have ever yet appertained to me, all being transacted by my father the Rajah Mooda of Rhio. But to meet my friend gives me great pleasure as it is a sign of his friendship and regard for me. I send a Chiefman with this. „Further, as to the letter which my friend sent me previous to his leaving Malacca, I received it and sent it to my father the Rajah Mooda of Rhio." 
my head Malays at the request of the Minister to remain on shore till the letter in question could be written out. About eight o'clock past meridian the letter was accordingly brought off, when we immediately got under weigh and proceeded to Rhio.

We anchored at Rhio early in the morning of the tenth; when the customary salutes between the Fort and ship were exchanged. About 9 o'clock a messenger I had sent to the town to announce my arrival returned with many complimentary congratulations on the part of the Rajah, who desired him to acquaint me that every thing would be in readiness on shore the following morning for our reception. In the course of the day presents of poultry, vegetables, fruit, etc. were sent off to the ship. On Monday morning at ten o'clock, the state-boats and many others under charge of the Shahbandar came alongside and conveyed us to town, where we were received by the Rajah with every honorary compliment and the most friendly attentions.

After the first audience was over at which all the princes, nobility and head men of the place attended, we were conducted by the Rajah to a very comfortable house, which he had prepared for our accommodation. In the course of the afternoon I sent over the presents intended for the Rajah; they were received in a very gracious manner.

In the evening I held a private conference with His Highness at my own quarters where I explained more fully the object of my mission and finding that he took a very favourable view of the subject, I at once presented him with a copy of the treaty in Malay language, which after perusing with great attention and having the exact purport of every clause particularly explained, he said he saw nothing whatever to object to in any of the articles: however with my permission he would take it home with him and give me his final opinion in the course of the following day, which he accordingly did agreeing to subscribe to all the terms without alteration. On Wednesday the nineteenth of August, the treaty was formally signed by the Raja Mooda on behalf of the Sultan of Johore, Pahang and dependencies, which include Lingin, Rhio etc., and myself on the part of the Honourable Company. This ceremony took place at the Rajah's Palace under a royal salute from the fort and three vollies of small arms from my guard. The Rajah afterwards entertained us very hospitably at dinner where the different 
branches of his own family with all the principal chiefs were assembled. The following day I employed in visiting different parts of the Settlement and on Friday morning the twenty first I re-embarked under the same complimentary honours and accompanied by even a more numerous retinue of boats than on landing and nothing could have exceeded the friendly disposition of the Rajah to us during our residence on shore.

Bl. 401 noot 9. De brief dd. 29 Augustus 1818 van onze Commissarissen aan gouverneur Bannerman (Wolterbeek-verzameling) luidde aldus :

Nommés Commissaires pour prendre possession de Malacca et dépendances, Leurs Excellences les Commissaires-Généraux de S. M. le Roi des Pays-Bas nous ont chargés d'une lettre pour vous, que nous avons l'honneur de vous remettre ci-joint.

Nous profitons de cette occasion, Monsieur, de vous témoigner notre surprise, de ce que le Resident ad interim du Malacca nous a déclaré, ne pas pouvoir traiter avec nous relativement à la-restitution de Malacca et dépendances, et qu'au contraire il avait reçu l'orde positif de garder l'établissement jusqu'au retour du major Farquhar.

Depuis douze jours nous l'attendons vainement, et comme il est très possible que l'époque de son arrivée soit encore éloigné, nous sommes obligés de vous déclarer franchement, qu'il nous est pas permis de nous contenter, avec des excuses aussi vagues, vu, qu'un delai aussi long nous entrainerait dans des dépenses énormes, pourrait occasioner des disputes $(a)$ entre les deux Gouvernements, et serait entiérement contraire à la volonté et les ordres de nos Souverains respectifs.

Nous avons donc l'honneur de vous informer, que de notre côté tout est en règle pour prendre possession de cet établissement, et nous vous prions de vouloir nommer le plutôt possible une commission qualifiée à nous en faire la remise, suivant les traités de I3 Aôut I8I4, afin que nous puissions remplir les ordres de notre Gouvernement et satisfaire aux intentions de S. A. R. le Prince-Régent, qui se trouvent très clairement exprimés dans l'acte de restitution des Colonies dans l'Inde, appartenant aux Hollandais le I Avril I8I3,

(a) Er staat niet disputes, doch wat er wel moet staan, kan ik niet lezen. De Engelsche en Fransche bijlagen van Wolterbeek's verzameling, zijn buitengewoon slecht uit de origineelen overgeschreven. 
dont nous avons l'honneur de vous envoyer une copie authentique.

Bannerman's antwoord werd gegeven tusschen 20 en 22 September 1818 (de brief was niet gedateerd) en luidde aldus :

I had this day the honour of receiving your letter of the 29 August by H. N. Ms schoener Wilhelmina and as I had previously been informed of the return of major Farquhar to Malacca on the $I^{\text {st }}$ instant, I shall not reply to your communication so fully as I should otherwise have thought it my duty to have done.

In justice however to the British Government I must declare that after it had waited for the arrival of the Dutch authorities for nearly three years, I had during that time retained charge of Malacca at a considerable expence on account of His Netherlands Majesty, I did not expect to receive such a complaint from your Excellencies at a trifling delay of twelve or thirteen days and particularly as no notification of your approach had been communicated to this Government either directly or indirectly, an omission wholly incompatible with the transaction of public affairs.

A young and subordinate officer could not be employed to deliver the establishment to your Excellencies and it therefore became necessary to direct that the measure should be postponed for a few days until the return of major Farquhar, to which officer all the instructions, relative to the restitution of the settlement, had been confided.

I am glad however that your Excellencies have not met with a greater delay than fourteen days and trust that the arrangement for your occupation of Malacca will now be executed with promptitude and at the shortest time $(a)$ with mutual good understanding.

Bl. 403 noot 10. De brief dd. 22 October 1818 van Farquhar (Wolterbeek-verzameling) luidde aldus :

To

their Excellencies Rear Admiral Wolterbeek and J. S. Timmerman Thijssen Esq. Commissioners on the part of His Majesty the King of the Netherlands.

Gentlemen!

Adverting to the tenor of the conversation which took

(a) Er staat geen shortest time; doch wat er wel moet staan, kan ik niet lezen. 
place at the Governmenthouse on the evening of the I6 instant between Your Excellencies and myself relative to the probable views of the British Government, of forming a settlement at the Carimon islands or at some other eligible situation to the eastwards of Malakka, I am most solicitious to prevent any misunderstanding arising from ambiguity of expression upon such a subject. I therefore conceive it proper to apprize your Excellencies officially that friendly communications have already been made with the constitued authorities of Linga and Riouw and their permission obtained for examining and surveying the Carimon and neighbouring islands and also with a general concurrence in the views of our Government and that the subject is at present under reference of the Supreme Government at Bengal.

I have the honor to remain with due consideration

\section{Gentlemen!}

Your most obedient humble servant W. Farquhar.

Malacca 22 October I8I8.

Bl. 403 noot 11. De brief dd. 31 October 1818 aan Farquhar (W. V.) luidde aldus :

\section{A}

Monsieur le Major Farquhar Commissaire de S. M. Britannique.

\section{Monsieur!}

Les contracts que vous avez conclus avec les différents princes voisins, et dont vous avez eu la bonté de nous transmettre des copies, ont été pris par nous pour notification, pourtant avec l'intention d'en faire dans nos négociations l'usage le plus convenable, afin de ne pas interrompre la bonne intelligence, qui règne entre nos Souverains respectifs.

Cependant nous ne pouvons vous dissimuluer que cette confidence nous a paru un peu étrange, vu que les contracts conclus avec le Sultan de Riouw renferment quelques articles qu'il n'était pas en droit de signer avant d'en avoir averti au préalable le Gouvernement des Pays-Bas.

Votre lettre datée le 22 Octobre, qui est le résultat d'une conversation que nous avons eu ensemble, et dans laquelle vous convenez qu'en effet il existe un contrat dans lequel le sultan de Riouw consent à céder à la Compagnie des Indes Anglaises un territoire situé à l'est de Malacca, éveille notre attention, d'autant plus, que vous nous en avez fait 
une mystère, dans le temps que vous nous envoyâtes les copies des contracts.

Nous supposons Monsieur que lorsque le dit contract a été conclu et lorsque vous avez persuadé le sultan de Riouw à faire la cession mentionée, vous avez ignoré les relations qui subsistent entre le dit Sultan et le Gouvernement des Pays Bas. Et comme nous voulons continuer à traiter les affaires, dont nous sommes chargés par nos supérieurs, le plus amicalement et cordialement possible, nous avons l'honneur de vous informer en peu de mots: Que tout le royaume de Riouw, Johore, Pahang, après d'être révolté et avoir commis beaucoup d'hostilités contre nous, a été dans l'année 1784 entièrement soumis et conquis par la force des armes de la Compagnie des Indes, et donné par contract de 2 novembre ${ }_{1784}$ comme bien feudal à son Altesse le Princ Alsoe, Padoeka Sri Sultan Mahmoed et ses ministres et que dans le même contract le dit Sultan s'est déclaré formellement lui et ses descendants vasseaux de la Hollande.

Il est inutile de citer ici d'autres articles du contrat, vu, qu'ils résultent tous de la déclaration de dépendance susmentionée et nous jugeons, qu'il doit vous suffire de savoir que c'est le change de la guerre, qui nous a procuré le droit, et qu'il doit être respecté par toutes les puissances, ainsi que cela s'est pratiqué relativement à toutes les possessions conquises par les Anglais dans les Indes.

Comme depuis ce temps aucune circonstance n'a eu lieu, qui aurait pu rendre nul le dit contrat, nous nous faisons un devoir Monsieur! de vous prier, de porter nos informations sur ce sujet officiellement à la connaissance de votre Gouvernement, pour pouvoir éviter un temps de malentendus, qui pourraient être la cause de beaucoup de désagréments entre nos Gouvernements.

Quant à nous, nous sommes obligés en notre qualité de Commissaires de vous déclarer Monsieur, que nous ne pourons pas permettre au Sultan de Riouw, Johore etc. de céder le moindre territoire de Riouw , Johore, Pahang etc. ou des isles voisins, qui ont fait partie du ci-devant royaume de Johore et Riouw.

Nous avons l'honneur d'être avec la plus parfaite considération Monsieur!

Vos très humbles et obéissants serviteurs,

C. J. Wolterbeek.

J. S. Timmerman Thijssen.

Malakka le 31 Octobre I8I8. 
Farquhar heeft op dit schrijven den volgenden dag nog het onderstaande geantwoord:

Your letter of yesterdays date was received late this evening, and as the Chief Commissioner has signified his intention to depart to morrow morning, the shortness of the time precludes me from entering so fully in.7.. (a) thereto as the subject requires. In the meantime I desire to assure your Excellencies in explicit terms that the copies of treaties I had the honour to transmit you, embrace bona fide the whole of the different articles concluded by me with the eastern Rajahs, and that the ulterior arrangement (to which I imagine your letter refers) is a separate and distinct matter, and which did not even become a subject of discussion until my return to Malacca.

I purposely abstain from doing more at present, than soliciting your Excellencies attention and reconsideration of the circumstances immediately and intimately connected with the capture of this settlement in 1795 , when it came into the British possession, the measures that were adopted at that time for giving entire and complete effect to the absolute independance of Sultan Mohammed at Riouw, Lingen etc. and that the exclusive control and heretidary possessions were secured to him by a pledge of British authority. No circumstance has since occured to invalidate such definitive negociation; it will therefore be obvious to your Excellencies that any references to arrangements respecting the former Dutch Company (which has long ceased to exist) have no relative analog to the present subjects and I may moreover add have hitherto formed no part of $(\ldots . b \ldots)$ our deliberations on the transfer of Malacca. The public documents which passed at the time I allude to, are still extant and to them I would individidually refer pending an appeal to our respective Governments.

It may be proper however previous to concluding this letter to draw your Excellenties attention to the $4^{\text {th }}$ article of the treaty of commercial alliance existing between the British Government and the sultan of Johore and Pahang, in which it is expressly stipulated, that the latter shall not renew any obsolete or interrupted treaties with other nations, the pro-

(a) De copiist schreef hier "in uply".

(b) Het eerste woord van dezen tusschenzin kan ik niet lezen, die overigens Ler are luidt ". . now necessary to be introduced into". 
visions of which may in any degree exclude or obstruct the free trade of British subjects.

Malacca I Novembre I8I8.

Bl. 404 noot 12. Zie het contract dd. $26-25$ November 1818 bij Netscher bl. 254-257. Het werd gesloten den $26^{\mathrm{n}}$ en bezegeld twee dagen later. Netscher heeft het als bijlage XXXVII in zijn oorspronkelijken vorm doen afdrukken, doch onder mededeeling, dat de beëediging enz. op den 27n November 1819 plaats vond; ik vond echter in de stukken steeds den $28^{\mathrm{n}}$ vermeld.

Zie hier hoe, volgens een van Malakka te Calcutta aangekomen reiziger, het Calcutta Journal van 5 Februari 1819 Wolterbeek's bezetting van Riouw verhaalt (Wolterb. verz.):

Shortly after the restoration of the settlement of Malacca to the Dutch, intelligence by report from Penang reached the ears of the Commissioners, that our Government had in contemplation to form a settlement on one of the Carimons of which the Rajah of Lingen, the propietor of all that chain of islands had tendered a grant voluntarily through major Farquhar.

This seemed to cause their Excellencies much disgust and alarm, but with a view of being beforehand with us, and putting in a death blow to our plans, they hastened the dispatch of their expedition to Riouw, the Rajah of which is connected with the Rajah of Lingen by blood and possesses a controlling authority over him. Having succeded in compelling this chief to cede one half of his revenues and resign his government into their hands, the Dutch imposed terms on the other, which, though not exactly similar in all their details, made him at least acknowledge his vassallage, and admit their supremacy over all his possesions and dependencies, including the ancient country of Johore, and the famous golden settlement of Pahang, on the other side of the peninsular. A royal salute was fired at Malacca, on the receipt of this glorious intelligence, to announce to the settlement the succes and triumph of their... (a).

The expedition, above mentionned, was conducted by the first commissioner in person, rear-admiral Wolterbeek, and previous to his departure, a communication from their Excel-

(a) De copiist heeft hier geschreven "their sherness".

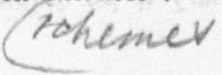


lencies, the Commissioners, was received by major Farquhar, couched in very high and menacing language, declaring their determination to consider the Rajahs of Riouw and Lingen, as their vassals and as such they say: «We will not permit either of them to cede one inch of ground to the English".

'Bl. 404 noot 13. Het "manifest" dd. 25 Mei 1819 bij Netscher bl. $249-251$.

" 404 noot 14. Het schrijven van Timmerman Thijssen dd. 3 Januari 1819 (W. V.) luidt aldus:

\section{Waarde en Hooggeschatte Vriend!}

Mijne vreugde te beschrijven, toen ik Uwe letteren ontving, wegens de zaken te Riouw is onmogelijk. Onze commissie is dus in alle opzichten honorabel geeindigd, en met en door UHEdG. ben ik teruggebracht tot den stand van eer en aanzien, waarvan dwalingen mijner jeugd mij eenmaal verwijderden, en die haat, afgunst en laster in Indië (echter en, bij God alleen bekend, onverdiend) mij bijna voor altijd deden missen. Ik ken Uwe vriendschap mijwaarts, en genoeg dat ik zeg, Uwe vriend is thans gelukkig, en zal nimmer vergeten, dat de edeldenkende baron. Van der Capellen mij door mijne benoeming tot den post, welken ik nu bekleed, aan Vorst, Vaderland, Gade en Kinderen teruggaf, want in droetgeestige oogenblikken te Kedang Allang wilde ik dikwerf een leven eindigen, dat mij een last was geworden, omdat $\mathrm{ik}$ het beschouwde te zijn zonder eer! Ontvang mijne hartelijke gelukwenschingen met al Uwe verrichtingen; God hoop ik zegene UHEdG. verder en voere mijn vriend eenmaal gezond en gelukkig aan het verlangde gade- en kinderhart; (dit onder ons) mijn vrouwtje en ik in ons stil huiselijk morgengebed vergeten $U$ nimmer aan het Opperwezen aan te bevelen, en worden onze smeekingen verhoord, dan drukt gij de lievelingen van $U_{w}$ hart spoedig aan hetzelve, en eens met hen vereend, vergeet dan $U w$ vriend niet, die $U$ als een broeder bemint. Mijn lot zal nimmer wezen Europa terug te zien (a); dan mijn zoon, die zich daar bevindt, beveel ik Uwe zorgen aan.

Ik heb volgens UHEdG. verzoek de Leewerik niet kunnen terugzenden naar Riouw; want moest dezelve gebruiken om bezit te gaan nemen van Perak. Ik vreesde den majoor

(a) De Gouverneur is den $14^{\mathrm{n}}$ Januari 1823 overleden. 
Farquhar, die juist het geluk had, dat twee Compagnie's kruisers alhier arriveerden, zulks zoude gedaan hebben. Ik heb dus mijn ouden getrouwen Teunis gezonden met de zes duizend matten, en vier stukken kanon in twee prauwen, en hoop alles wel zal lukken.

Daar Walbehm (a) ons nu weder is afgenomen, verlang $\mathrm{ik}$ hartelijk, dat een paar goede jongelieden herwaarts worden gezonden, want Baumhauer $(b)$ heeft geen assistentie genoeg; met Andriessen $(c)$ gaat het wat beter, maar met De Wit $(d)$ is het nog hetzelfde.

Het bewuste papier wegens Malakka is in mijn handen; dan het heeft mij moeite gekost, en had ik niet doorgetast, door den bij $\mathrm{u}$ bekenden persoon met arrest te dreigen, en aan UHEdG. op te zenden, indien hij langer uitvluchten gebruikte, dan had ik het niet machtig geworden. Ik zal het met eene secure gelegenheid zenden en verzoek vriendelijk het den Gouverneur te doen zien.

Ontvang waarde Vriend den oprechtsten nieuwjaarsgroet en zegenwensch van mij, mijn vrouwtje en alle aanhoorigen en geloof mij onveranderlijk te zijn

Uwe Heilbiddende en oprechte vriend

J. S. Timmerman Thijssen.

Bl. 405 noot 15. Er is hier eene vergissing. Bedoeld wordt de op bl. 426-427 vermelde correspondentie, doch de brief van Moira (Hastings) is van 14 Januari 1820 (door Spengler juist vermeld op bl. 97), terwijl het antwoord van Van der Capellen de door Spengler wedergegeven dagteekening dd. 16 April d. a. v. draagt. In Moira's brief wordt enkel geklaagd over Timmerman's "indiscret language, which he hold on this occasion" nl. op het vernemen van Singapore's bezetting; doch Van der Capellen schrijft aan Moira :

"Votre Excellence sait que j’ai refusé la ratification du traité conclu par le gouverneur de Malacca avec les sultans de Salangore et de Rambou, parce qu'il avait été stipulé un monopole de l'étain en notre faveur; mais elle ne sait peut-être pas que ce même gouverneur a été fortement

(a) Een klerk bij den Raad van Justitie.

(b) De gewestelijke secretaris.

(c) Een commies.

(d) Een klerk op het gewestelijk bureau. 6e Volgr. V. 
réprimandé pour avoir écrit au Roi de Siac une lettre dont l'esprit ne s'accordait point avec les sentiments d'amitié envers la nation anglaise qui doivent caractériser toutes nos démarches." -

Wat betreft den lof, die, volgens den aanhef van bl. 405 , van Engelsche zijde aan Thijssen's tact werd toegebracht, ik heb hiermede op het oog een particulier schrijven dd. 25 Januari 1819 uit Malakka, hetwelk in het Calcutta Journal van 9 Maart 1819 werd opgenomen en aldus luidde (Wolterbeek-verz.):

Trade goes on in the usual way, with this difference, that there is no distinction paid to flags, the same duty being levied on goods (whatever bottoms they may be imported on) as were exacted from British ships, when our flag was flying.

Timmerman is quite the gay man, lives in a liberal style, and is very attentive to strangers. We have now the benefit of some American trade, which was before excluded $(a)$, and unless new regulations make their appearance from Java $(b)$, we see no reason why this place should not improve as a free port under the present system.

Bl. 406 noot 16. Namelijk om mede te deelen (B): "at what time and by what conveyance" bevelen naar Benkoelen werden gezonden "for the relieved troops at that station to proceed to a position whence they could be available for the purpose of garrisoning any post occupied by us in the states of Rhio, Lingen and Johore."

Bl. 406 noot 17. Men leest namelijk in Raffles verantwoording (B):

I request to state that I did not issue any order or official instruction on the subject, but in a private to $\mathrm{Mr}$. Jennings I intimated my wish that the transports might return by that route. I did so on two considerations, first, because experience had shown that in the adverse moonsoon, which was then blowing in the bay, the best passage was likely to be made by that route, and secondly, because it would not only

(a) Wegens den oorlog tusschen Engeland en Noord-Amerika.

(b) Commissarissen hadden de vrijzinnige tariefregeling getroffen, ten einde "den handel op Malakka daardoor te zullen animeeren tegen den handel op Prince of Wales' eiland, totdat H. H. E. E. Commissarissen-Generaal, nader daaromtrent zouden hebben gedecideerd", leest men in Wolterbeek's Journaal. 
be convenient for me to fall in with them, but in case of necessity to avail myself of their services.

This intimation to Mr. Jennings was to the best of my recollection dated after I had left Calcutta, at the Sand Heads, the beginning of December, and the letter was sent with my other private letters for Bencoolen to the care of captain Ashmore, who was then in Calcutta, and who I believe sailed from thence for the West Coast in January - it was received at Bencoolen in March.

Bl. 406 noot 18. Bij Boulger bl. 305 leest men over dezen troepenquaestie het volgende :

Raffles, on leaving Calcutta, and while still off the Sandheads, sent orders to Bencoolen for the relieved troops from that place to return to Bengal by the Straits of Sunda, so that he might fall in with them on his journey south of Malacca, and, in case of necessity, avail himself of their services. This arrangement was another proof of his forethought; but, as it turned out, his instructions did not reach Bencoolen until March, by which time the fate of Singapore had been settled. Raffles was called to account for this step of his in moving troops; but, in the pressure of other matters, and owing to the point not arising until after it had been decided to retain Singapore, the measure was condoned.

Wanneer men onder dit condoned moet verstaan, dat Raffles er niets verder na zijne verantwoording van hoorde, dan is dit niet juist. Want de brief dd. $22 \mathrm{Juli}$ 1820 van den gouvernementssecretaris C. T. Metcalfe uit Calcutta luidde aldus (B):

I am directed to acknowledge the receipt of your letter of $3 \mathrm{I}^{\text {st }}$ ultimo, in reply to mine of the $\mathrm{IO}^{\text {th }}$ July, on the subject of the directions which you issued regarding the disposal of the relieved troops at Bencoolen.

The Governor-General in Council desires me to observe to you, that His Lordship cannot consider that proceeding as justified by your explanation, and deeply regrets:

First. That you should have issued orders from the Port of Calcutta without the previous sanction of the GovernorGeneral in Council; and

Second. That you should have done so, under any impression whatever of the expediency of the measure, without at the same time reporting the proceeding for the information of his Lordship in Council. 
Op deze troepenbeweging hebben ook betrekking de volgende mededeelingen van den $\mathrm{w}^{\text {nd }}$ resident Farquhar dd. 7 April 1819 an den Gouvernementssecretaris te Calcutta (B):

I have the honour to acquaint you for the information of the Most Noble the Governor-General in Council, that the remainder of the relieved troops from Bencoolen arrived here safe on the $30^{\text {th }}$. Ultimo, and that this garnison now consists of 4 companies of the $\mathrm{I}^{\text {sts }}$ battalion, $2 \mathrm{O}^{\text {th }}$ regiment, a detachment of 29 European artillery and 25 Golundauze (a).

En dd. 8 April 1819 (B):

I have the honour to acquaint you for the information of the Most Noble the Governor-General in Council that, the transports Cornwallis en James Scott having landed at this place the troops and stores embarked at Bencoolen, their Commanders have been directed to make the best of their way to Calcutta, communicating with the Port of Prince of Wales' Island in passing, in order that, that Government may if necessary avail themselves of the spare tonnage of these vessels to Bengal, where in conformity to the tenor of their charters they are only dischargeable.

Bl. 4.07 noot 19. Zie de acte dd. 6 Februari 1819 bij Netscher bl. 266 vv. en Raffles' proclamatie op dien dag bij Boulger bl. 313 .

" 407 noot 20. Zie de brieven bij Netscher bl. 269 vv.

" 407 noot 21. Zie de brieven bij Boulger bl. 314-315.

" 408 noot 22. Raffles zond namelijk het volgend schrijven uit Pinang naar onzen Gouverneur van Malakka (Wolterbeek-verz.):

\section{To}

His Excellency Timmerman Thijssen, Governor of Malacca.

\section{Sir!}

I was on the point of addressing Your Excellency for the purpose of apprizing you of the establishment of a British factory at Singapore, when I received from the Governor and Council of this island a copy of the letter which Your Excellency addressed to him on the ro instant with the documents therein referred to.

(a) Wat Golundause zijn, weet ik niet. 
I have now the honour fo inform Your Excellency, that in pursuance of instructions from the Supreme Government of British India, and by virtue of the authority vested in me as agent to the Most Noble the Marquis of Hastings K. G. etc. etc. Governor-General, by the commission of which I have the honour to inclose a copy in this letter, I have entered into and concluded a treaty and defensive alliance in the name and on behalf of the Governor-General with their Highness Sultan Hussein Mohammed Sjah, eldest son and legitimate heir and successor of His Highness the late Sultan Mohammed Sjah and Datoo Toomengoeng Sri Moharadja Abdul Rahman, Toemengoeng of that division of the empire called Johore proper.

By the stipulations of this treaty, a British factory has been established at Singapore and the port and island placed under the protection of the British flag, but as the views of our Government are strictly commercial and as I was earnestly desirous of avoiding collision with the subjects of our ally, His Majesty the King of the Netherlands, whom I understood to be established at Rhio, it has been provided by the treaty, and form a part of it, that the British government is no way bound to interfere with the politics of the adjacent states of Rhio, Linga etc. or to assert the Sultans authority beyond that portion of the empire, in which it is now voluntarily acknowledged.

From your letter to the Governor and Council of this island, it would appear that you have done me the honour of addressing a letter to me, which I have not yet received, in which you make a protest against the occupation of Singapore. I have perused with attention the documents to which you refer in your letter to the government of this island, and do not find in there any thing to effect or invalidate the arrangements I have made at that island; in the event therefore of any difference of opinion on this subject I beg leave to refer You to the immediate authority under which I act, and to request that You will do me the honour to transmit a copy of this dispatch to His Excellency the GovernorGeneral at Batavia by the earliest opportunity.

I have the honour to be

\section{Sir}

Your Excellencies most obedient humble servant

Prince of Wales Island

T. S. Raffles.

the 17 Februar I8I9. 
Bl. 408 noot 23. Thijssen's brief, gedagteekend Malakka 3 Februari 1819, aan Wolterbeek luidde aldus (W. V.):

\section{Hooggeachte Vriend!}

Met verwondering zal mijn vriend deze letteren lezen, hoorende, dat Sir Thomas Stamford Raffles met den majoor Farquhar bezit heeft genomen van het eiland Singapore. Ik heb zeer omstandig over deze zaak aan Z. E. den GouverneurGeneraal geschreven en twijfel geenszins of ZHEdG. zal UHEdG. daarvan visie geven. Intusschen weet, dat alles een spoedig redres vereischt, want indien mijne rapporten goed zijn, heeft zich de zoogenaamde erfprins Toekoe Long gesteld onder de protectie van de Engelschen; deze deugniet heeft sinds lang gezocht zijn broeder den sultan van Linga van den troon te storten en zal zulks misschien nu gelukken, daar hij zich heeft vereenigd met den moordenaar der Nederlanders te Palembang. De heer Koek $(a)$ is sukkelende; anders zond ik ZEdG. naar Riouw. Ik hoop echter, dat de Resident met de versterking van 5o koppen en de twee kruisers, die ik hem heb gezonden, genoegzaam in staat zal zijn zich te verdedigen, en dat eene spoedige assistentie van land- en zeemacht de Indische vorsten zal doen zien, dat het Nederlandsch Gouvernement getrouwe bondgenooten weet te ondersteunen en meineedigen te straffen; ik zal hier niets meer bijvoegen, want ik weet, dat het lot van Malakka en onderhoorigheden en dat van Uw vriend UHEdG. ter harte gaat.

Ontvang, waardig vriend! de voortdurende verzekeringen van vriendschap van mijne goede vrouw, mij zelven en de geheele familie en wees verzekerd ik oprecht en met hoogachting ben

\section{Hooggeachte Vriend!}

Uw Heilbiddende vriend

J. S. Timmerman Thijssen.

Bl. 408 noot 24. De brief van Timmerman Thijssen, gedagteekend Malakka 21 Februari 1819, aan Wolterbeek luidde als volgt (W. V.) :

(a) A. Koek, „Raad van Justitie, en zoowel bij den inlander, als bij het Gouvernement zeer gerespecteerd, bejaard man", schrijft Wolterbeek in zijn journaal ad 22 Augustus 1818, toen de overgave van Malakka nog niet had plaats gevonden. Na die overgave, werd Koek aangesteld tot „secunde” van den Gouverneur en tevens tot president van den Raad van Justitie te Malakka. Boulger schreef den naam onveranderlijk verkeerd Kock. 


\section{Waarde Vriend!}

Mijne letteren van den $3^{\text {en }}$ Februari zullen UHEdG. voorzeker zijn ter hand gesteld, en daardoor bekend zijn geraakt met mijne omstandigheden alhier. Ik kan UHEdG. niet genoeg betuigen de menigte oogenblikken van verdriet, die ik slijt; geen geldzucht bracht mij naar deze plaats; ik heb genoeg, gelukkig, om in stilte te kunnen leven; dus mijne wenschen waren enkel eer; en nu weet ik dikwerf niet, hoe te handelen. Ga ik te ver of doe ik te weinig, het zal altoos op mijn hoofd neerkomen. Had ik macht genoeg dan zoude ik niet in onzekerheid zijn, want op verzoek van onzen bondgenoot, dien wij assistentie beloofd hebben, wordt zijn land geïnondeerd, zoude ik geen oogenblik aarzelen, eerst in het vriendelijke de Engelschen te verzoeken weg te gaan, en zulks niet doende, met geweld weg te jagen; nu kan ik niets doen. - Goede God, hoe konde Koek zoo dwaas zijn Toekoe Long, dien hij zelf wilde gebruiken als een oproermaker, indien Radja Moeda en de Sultan geen behoorlijk contract wilden maken met het Nederlandsch Gouvernement, op zich zelven te laten; hij had dezen Prins òf moeten laten medeteekenen en voor hem zorgen, dan wel van Riouw verwijderen en naar Java zenden. - $\mathrm{Nu}$, waarde vriend, het ligt er toe, en zorg toch ik dadelijk geholpen worde. Kan het zijn, kom dan mede, dan kunnen wij voorzeker nuttige plannen beramen. Uwe meerdere ondervinding, uwe meerdere jaren zullen mij tot nut zijn, want ik ben hier geheel alleen, en heb buiten Baumhauer niemand, doordien Parvé niet altoos in een en hetzelfde humeur is, en wezenlijk na de opofferingen, die ik voor hem gedaan heb, mij niet behandelt, zooals het behoort; zulks blijft echter onder ons $(a)$.

Mijn vrouwtje en verdere familie vereenigt zich met mij UHEdG. op het vriendschappelijkst te salueeren en noeme mij met alle achting

\section{Waarde Vriend!}

\section{Uwe Oprechte Vriend}

J. S. Timmerman Thijssen.

Bl. 411 noot 25. Wolterbeek had hiermede op het oog de brieven van 23 en 26 Augustus 1795 door Couperus geschreven aan den sultan van Riouw en aan de regeering te Batavia, medegedeeld door Netscher bl. 239-240.

(a) J. A. Stein Parvé was te Malakka „Kollecteur van de in- en uitgaande rechten". Men verwarre hem niet met den schrijver D. C. Stein Parvé. 
Bl. 411 noot 26 . Wolterbeek bedoelt de sub 10 en 11 wedergegeven brieven. De brief van de Commissarissen is echter volgens de Wolterbeek-verzameling gedateerd, niet 28 October, gelijk in het verbaal staat, doch 31 October.

De verdiensten van den Engelsche Compagnie's zeekapitein Ross, door Wolterbeek een paar regels te voren genoemd, werden door de Court of directors dd. 17 Januari 1821 erkend met eene fraaie gratificatie: "Resolved, that as a mark of the court's favorable consideration of the highly important services rendered by Capt. Daniel Ross, of the Bombay marine, during the period of fourteen years, in which he conducted the survey of the China seas, and furnished many valuable charts, to be presented with the sum of fifteen hundred pounds (\& 1500)..."

The Asiatic Journal Vol. XI (London 1821) bl. 413. In hetzelfde deel, doch op bl. 512, een uitvoerig rapport dd. 7 Februari 1819 van Ross betrekkelijk de opueming van Singapore.

" 413 noot 27. Zie den brief sub 157 Opvattingen. Dit was niet het eerste bericht naar Holland over de zaak. De Gouverneur-Generaal had reeds bij brief dd. 25 Februari 1819 het departement van Koloniën de stichting gerapporteerd (verg. sub 39) en dd. 18 Maart hierover nadere inlichtingen verstrekt. Laatstbedoelde brief bij V. D. bl. 278 bijlage LXIV; dit schrijven vangt aldus aan, volgens het door mij geraadpleegde archiefstuk:

Ten vervolge van mijne secreete missive van den 25 February 1l. $\mathrm{n}^{\circ}$. I, heb ik de eer Uwe Excellencie bij deze te informeeren, dat nadere berigten door mij zijn ontvangen, omtrent de verrigtingen van den Heer Raffles, te Sinkapore, in het Rijk van Rio, Linga, Johor en Pahang, en welke berigten de vroegere geheel bevestigen.

Uit deze stukken is mij verder gebleken, dat de heer Raffles zijne handelingen wil doen voorkomen, als het gevolg.... enz.

Van Deventer laat echter dit begin zonder eenige aanwijzing weg, zoodat de brief aldus opent:

Uit de nadere berigten, bij mij ontvangen, omtrent de verrigtingen van den heer Raffles te Singapore, is mij gebleken, dat hij die wil doen voorkomen, als het gevolg .... enz. 
Zulk een manier van overneming der officieele stukken komt mij niet zonder bedenking voor.

Bl. 413 noot 28. Zie het artikel in het Asiatic Journal van April 1821, dl. XI bl. 317 vv.

" 414 noot 29. In de Indische brieven van 9 en 30 Juni 1818 in Opvattingen bl. 386 en 388 (ov. 46 en 48).

" 414 noot 30. Zie Opvattingen bl. 389 (ov. 49).

" 415 noot 31. Zie Opvattingen bl. 402 (ov. 62).

" 4.15 noot 32. V. D. bl. 277.

" 4.16 noot 33. Zie Elout's particulier schrijven dd. 9 Juni 1818 in Opvattingen bl. 410 (ov. 70).

" 416 noot 34 . Elout's bedreiging om Java eenvoudig te bezetten, vinden wij medegedeeld in ondervolgend opmerkelijk schrijven van den Nederlandschen ambassadeur te Londen, Fagel, dd. 11 October 1816, aan onzen minister van Buitenlaudsche Zaken Van Nagell:

J'espére que le delai survenu dans la rétrocession de Java sera estimé on your side of the water à la juste valeur. Je conçois parfaitement que cela dérange $\mathrm{Mess}^{\mathrm{rs}}$ les Commissaires, et cela les met dans une fausse position qui est toujours désagréable: mais je n'ai pas besoin de vous dire que le Gouvernement ici n'est pour rien dans tout cela, et n'a pas la plus légère intention d'éluder le Traité. Le fait est qu'avant la reception formelle des ordres, les employés Britanniques ne sont pas -autorisés à faire la cession, et seraient même dans le cas d'être punis s'ils la faisaient. Pour ce qui est des chicanes et des prétextes au moyen desquels ils semblent disposés à différer cet acte, il faut considérer que quoique chefs à Java ils ne sont au fond que des subalternes ailleurs et que le désir de prolonger autant que possible leur existence politique (surtout sous le rapport de la finance) peut paraître de leur part assez naturel. Voilà ce que je me suis dit d'abord en lisant les lettres de nos Messieurs, et ce que lord Bathurst luimême m'a depuis lors donné à connaître avec sa candeur accoutumée. Je n'ai nul doute que d'ici à quelques semaines nous apprendrons que la prise de possession a été effectuée sans aucune difficulté. En attendant je suis enchanté de savoir l'expédition heureusement arrivée à sa destination. Mr. De 
Capellen m'annonce d'autres lettres expédiées avant celles-ci par le brik (du Roi) le Spion et par le navire Britannique le Régent: mais elles ne sont pas encore arrivées et cela ne m'étonne pas car le navire qui a apporté celles-ci a eu un trajet singulièrement court, étant parti de Java le 2 Juillet et arrivé à Plymouth le 7 Octobre. Excusez toutes ces ratures et croyez je vous en prie à mes sentiments invariables.

H. Fagel.

Aprés avoir écrit ce qui précède, j'ai eu la visite de $\mathrm{Mr}$. Goulbach, dont je vous rends compte dans mon rapport officiel: d'après la lecture, qu'il m'a faite des dépêches originales Anglaises, il me parait que le 28 les employés Anglais étaient occupés in good earnest à tout préparer pour effectuer la cession au moment où leurs ordres arriveraient. Ils se plaignent un peu dans leur rapport (entre nous s'il vous plait) de la vivacité de $\mathrm{Mr}$. Elout, et elle perce dans ses lettres à moi, ce qui me fait craindre qu'il n'en soit de même dans son rapport officiel. Je vous envoie ci-joint tout ce que j'ai reçu de ces Messieurs avec prière de me le renvoyer. Je leur ai repondu par le Génl. De Kock, au moins j'espère que mes lettres (envoyées hier à Portsmouth) seront arrivées à temps. La communication par..... (een woord onleesbaar) que Mr. De Capellen dit à la fin de sa lettre n'avait pas encore été faite par le Lieut.-Gouverneur, est sans doute celle qui a été adressée (suivant les depêches Anglaises) aux Commissaires le 28 Juin. Ces mêmes depêches disent que les ordres sont attendus de Calcutta d'un moment à l'autre.

Je vous écris tout ceci, mon cher Monsieur en confidence, comme vous vous en appercevrez assez au stile décousu de ma lettre, mais je n'ai pas le temps de la copier ou d'en écrire une autre. Dans le rapport Anglais (qui m'a été communiqué comme vous comprenez de la même manière) il est rendu un compte détaillé d'une des conférences qui doit avoir été un peu chaude, Mr. Elout ayant donné à connaître à la fin qu'en cas de besoin il $\mathrm{y}$ avait assez de troupes à bord de notre escadre pour PRENDRE L'île $(a)$.

Bl. 416 noot 35 . Zie Opvattingen bl. 382 vv. (ov. 42 vv.)

" 417 noot 36 . Zie Opvattingen bl. 407 (ov. 67).

" 419 noot 37 . Boulger bl. 319 .

(a) In den brief dubbel onderstreept. 
Bl. 419 noot 38 . Boulger bl. 327 .

" 420 noot 39 . Het besluit dd. 25 Februari 1829 luidde aldus:

Gelezen de missives van den Gouverneur van Malakka dd. I, 2, 3 en 6 Februari ll. $\mathrm{N}^{\text {os }} 3,4,5$ en 7 en van den Resident van Riouw dd. .... en I6 Februari Il. Nos 2 en 4, alle betrekking hebbende tot eene poging, welke van de zijde der Engelschen schijnt te worden gedaan om eene bezetting op te richten ten oosten van Malakka en wel bepaaldelijk op het eiland Singapore, eene onderhoorigheid van het rijk van Djohor, Pahang, Riouw en Linga.

Blijkende uit deze eenigszins verwarde berichten, dat eene Britsche macht, onder aanvoering van den ridder Raffles en den majoor Farquhar zich tot het voorschreven einde naar Singapore heeft begeven, na vooraf eene vruchtelooze poging te hebben gedaan, om daartoe de toestemming van den Onderkoning van Riouw te verkrijgen.

Dat de Gouverneur van Malakka tegen deze handelingen heeft geprotesteerd bij eene missive door hem aan den Luitenant-Gouverneur van Benkoelen gezonden.

Dat hij den vorst van Riouw, Linga enz. heeft aangemaand om de Engelschen tegen te gaan, en hem daartoe de hulp der Nederlandsche Regeering heeft toegezegd.

En dat eindelijk de Gouverneur van Malakka het voor nuttig houdt, dat het garnizoén aldaar worde versterkt, ten einde bezettingen te kunnen afzonderen voor de kleine eilanden en posten in de straat gelegen.

Hierna wordt door den Secretaris van Staat, GouverneurGeneraal, de hierna volgende nota gelezen, over den inhoud der ontvangen depêches van den Gouverneur van Malakka.

NOTA.

Uit de eenigszins verwarde berichten, door den Gouverneur van Malakka ingezonden, blijkt het bijna met zekerheid, dat eene Britsche macht onder aanvoering van den heer T. S. Raffles en den majoor Farquhar voet aan wal gezet heeft op het eiland Singapore.

Dit eiland is eene onderhoorigheid van het rijk van Linga, Djohor, Pahang, Riouw, enz.

Met den Sultan van dit rijk heeft het Nederlandsche Gouvernement den $26^{\mathrm{n}}$ November 1818 een tractaat gesloten.

$\mathrm{Bij}$ dit tractaat is het vorige van den $\mathrm{IO}^{\mathrm{n}}$ November 1784 vernieuwd, en mitsdien heeft de Sultan evenals voorheen erkend te zijn een vassal van Z. M. den Koning der Neder- 
landen, en zijn rijk te bezitten als een wettig en onsterfelijk leen der Nederlanden, evenals zijn vader hetzelve bezeten had.

Het tractaat van 1784 is nimmer vernietigd of veranderd en de status ante bellum was op hetzelve gegrond.

De daąd van den voormaligen Gouverneur Couperus, die gezamentlijk met de Britsche autoriteit te Malakka, in 1795 Riouw aan den Sultan afgestaan heeft, is nimmer door het Gouvernement gehomologeerd of goedgekeurd, en is diensvolgens nul en van geene waarde.

Uit krachte van het tractaat tusschen Zijne Britannische Majesteit en den Koning der Nederlanden gesloten den $13^{\text {n }}$ Augustus 1814, is Malakka aan het Nederlandsche Gouvernement overgegeven.

Het spreekt vanzelve dat tot Malakka behooren, alle de onderhoorigheden van dat Gouvernement, zooals dezelve vóór den oorlog met Engeland daaronder behoort hebben. Het rijk van Riouw, Linga, Djohor, Pahang, enz. is te voren aan het Gouvernement van Malakka onderhoorig geweest. Diensvolgens moet het ook nu wederom gecenseerd worden, het lot van Malakka te volgen. En men kan aan geene vreemde mogendheid het recht toekennen, zich meester te maken van, of eene bezetting te leggen op het grondgebied van dat rijk.

Wij zien dit evenwel nu gebeuren. Men verzekert ons, dat Singapore door de Engelschen bezet is, dat de majoor Farquhar zich bij den Onderkoning te Riouw vervoegd en hem den afstand van een gedeelte van het grondgebied gevraagd heeft. Dat de Onderkoning van Riouw op grond van de met de Nederlandsche regeering aangegane verbintenis, zijn aanzoek heeft van de hand gewezen, waarop evenwel de Majoor van Riouw naar Singapore zoude vertrokken zijn.

Wat kan hem hiertoe de bevoegdheid geven?

De brieven van Commissarissen tot de overneming van Malakka, leeren ons, dat de majoor Farquhar op naam der Engelsche Oost-Indische Compagnie, een zoognaamd tractaat heeft aangegaan met den Sultan van Riouw, Linga, enz. in Augustus jl., dus zeer korten tijd vóór de bezitneming van Malakka, en toen men wist dat dezelve eerstdaags moest plaats hebben.

Behalve nu dat de Sultan niet de bevoegdheid had een zoodanig tractaat te sluiten, of liever dat dezelve alle kracht van zelve moest verliezen, na de teruggave van Malakka, daar 
de Sultan nimmer als een onafhankelijk vorst kan beschouwd worden, heeft hij zelve dit stuk herroepen bij het $22^{\mathrm{e}}$ en $23^{\mathrm{e}}$ artikel van het tractaat van November $18 \mathbf{1} 8$, alwaar het volgende woordelijk staat: Art. 22. «Zoo is het, dat de Sultan zich verbindt dit Rijk te houden in zijn geheel, zonder daarvan ooit iets af te staan, aan eenige andere mogendheid, buiten toestemming der Hooge Regeering, gelijk alsmede de Sultan met geene andere natie, hoe ook genaamd, eenig tractaat zal mogen aangaan, zonder goedkeuring van de Nederlandsche Hooge Indische Regeering daartoe verkregen te hebben." En Art. 23. "En worden eindelijk bij dit tractaat vervallen verklaard alle vorige tractaten, zijnde dit het eenige nu van kracht."

Dit tractaat is door den Onderkoning van Riouw en den Toemengoeng van Djohor, plechtig in naam des Sultans op den Alcoran bezworen.

Uit dit bovenstaande blijkt genoegzaam, dat wij gegronde redenen van klachten hebben tegen de handelingen van de Britsche autoriteiten.

Indien zij tot hetgeen zij deden, gemachtigd zijn door den Britschen Gouverneur-Generaal, moet men veronderstellen, dat deze niet van den waren staat van zaken onderricht is.

Het is belangrijk hem daarmede bekend te maken, en met aandrang te verzoeken dat de gegeven bevelen herroepen worden.

Het is ook noodig dat de geheele zaak ter kennis gebracht worde van ons eigen Gouvernement in Nederland.

De heer Timmerman Thijssen schijnt in dit alles rasch en zonder behoorlijk overleg gehandeld te hebben, zooals hij ook het Gouvernement niet in staat gesteld heeft den waren staat van zaken te beoordeelen. $\mathrm{Hij}$ had meer volledige informatiën moeten inwinnen. Zijne voorstellen zijn ook niet aannemelijk. Wij moeten, hetgeen wij bezet hebben, door de noodige macht tegen de aanvallen van allen en tegen de woelingen der Inlanders beveiligen. Wij moeten door onze bedaarde houding, met eene goede macht ondersteund, het behoorlijk ontzag voor de Nederlandsche regeering inboezemen. Geene dadelijkheden behooren door ons gepleegd te worden, evenmin als door onvoorzichtige handelingen of geschriften daartoe de minste aanleiding van onze zijde behoort gegeven te worden. Geene plaatsen op welke wij tot dusver geèn bezettingen gehad hebben, moeten zonder klaarblijkelijk nut of zonder noodzalijkheid daarmede voorzien worden. Het is 
evenmin mogelijk als het raadzaam zijn zoude alle punten in de straat Malakka, Singapore enz. te bezetten, of op dezelven de Nederlandsche vlag te planten. Onze vestiging op Riouw en wellicht hierna nog op Linga moet voldoende geacht worden, en indien de beambten of krijgsbenden der mogendheid, met dewelke ons Gouvernement in de beste verstandhouding is, zich veroorloven zich op onbezette plaatsen van ons grondgebied in die streken neder te zetten, en na aanzegging van onze zijde zich niet verwijderen, moet daartegen formeel geprotesteerd, en voorts de klachten daartegen bij het Hooge Gouvernement in Bengalen en in Europa gebracht worden.

Deze gronden behooren gevolgd en de Gouverneur van Malakka behoort daarmede voorzichtiglijk bekend gemaakt te worden. Dit is noodzakelijk, om alle kwade gevolgen voor te komen, dat niet wederom als in vorige eeuwen de Indische Gouvernementen bestendig in de wapenen tegen elkanderen opkomen, terwijl onder de Gouvernementen zelve in Europa de volmaaktste vrede heerscht. Wij moeten van onze zijde niet gedoogen de handelingen, die de heer Raffles zich in Palembang veroorloofd heeft en waartegen wij met een goed gevolg bij zijn eigen Gouvernement gereclameerd hebben.

Uit de brieven van den Resident van Riouw kan verondersteld worden, dat de Toemengoeng van Djohor zich met de heeren Raffles en Farquhar naar Singapore begeven heeft, en hem behulpzaam is in het uitvoeren hunner voornemens. Deze is ondergeschikt aan den Sultan, heeft mede als zoodanig het tractaat geteekend en bezworen. Hij dient dus over zijn gedrag onderhouden en aan zijn plicht vermaand te worden.

Alle deze consideratiën zouden tot de volgende besluiten kunnen leiden :

$\mathbf{I}^{\mathbf{0}}$. Den Gouverneur-Generaal van Britsch-Indië de ontvangene berichten mededeelen, met eene beknopte opgave van den staat van zaken en de gronden van ons recht op het rijk van Riouw enz., en dringend verzoek zoodanige bevelen te willen geven, waardoor de bemoeienis omtrent plaatsen middellijk of onmiddellijk onder de Nederlandsche regeering sorteerende, voortaan worden nagekomen, en de goede verstandhouding bewaard, die wij van onze zijde zooveel mogelijk trachten aan te kweeken.

$2^{\circ}$. Den Gouverneur van Malakka onder het oog te brengen de wijze waarop het Gouvernement verlangt dat voortaan de 
zaken door hem en zijne onderhoorigen worden behandeld, en het oogpunt waaruit hij dezelve moet beschouwen; hem te kennen geven dat het Gouvernement in dit geval meer volledige en meer zekere berichten van hem had verlangd te ontvangen.

$3^{\circ}$. Den Gouverneur van Malakka te gelasten nauwkeurig te onderzoeken op welke plaatsen zich eene Britsche macht heeft gevestigd, en indien hij met volle zekerkerheid mocht ervaren, dat zij eene plaats, tot de onderhoorigheden van den Sultan van Riouw, Linga, enz., behoorende, hebben bezet, naar derwaarts een vertrouwd en bekwaam persoon af te zenden met eene beleefde missive aan de hoogste autoriteit aldaar, houdende kennisgave dat de plaats, waar zij zich bevinden, behoort tot de bezittingen van den Sultan van Riouw enz., vassal der Nederlanden; en dat hij dus verwacht dat zij dezelve na deze kennisgave zullen verlaten met verderen last aan den overbrenger dezer missive om, wanneer in de ontruiming zwarigheid gemaakt wierd, daartegen in naam der Nederlandsche Hooge Indische Regeering ten sterkste schriftelijk te protesteeren, en naar Malakka terug te keeren.

$4^{\circ}$. Den Gouverneur van Malakka te gelasten het gedrag van den Toemengoeng van Djohor te onderzoeken en hem op eene gepaste wijze zijne verplichtingen onder het oog te brengen.

$5^{\circ}$. Zoodra de moesson het zal toelaten eene gewapende zeemacht naar Malakka te zenden, om zich in die wateren te vertoonen, en de Inlandsche Vorsten aan hunne verplichtingen te herinneren; voorts het garnizoen van Malakka en Riouw op eene goede sterkte te houden.

60. Van deze geheele zaak kennis te geven aan den Minister van Koloniën.

Waarop gedelibereerd zijnde, is, naar aanleiding van de voordracht van den Secretaris van Staat Gouverneur-Generaal,

Goedgevonden en verstaan:

Eerstelïk enz. [volgen zes artikelen, gelijkluidend met de hiervoren vermelde zes punten.]

Bl. 420 noot 40. Ross schreef dd. 6 Maart 1819 aan Farquhar (Bg. bl. 317):

Dear Sir! On my way down the Straits I called at Malacca, and think it but right that you should be acquainted with my 
having learned from undoubted authority that the Governor of Malacca, about eight days ago, sent of a despatch to Batavia, recommending very strongly that a force should be sent up to seize the party now at Singapora, and urging the facility with which such a measure may be accomplished when they are not to receive reinforcements immediately. My authority is very good, and, had I not determined on calling here, I was about to take up a prow to convey the above information to you. It would appear to be from some information which the Governor received by a Malay ship from Penang, which induced his immediately sending off to Batavia.

Bl. 420 noot 41. F'arquhar's schrijven dd. 6 Maart 1819 aan Gouverneur Bannerman luidde aldus (Bg. bl. 316-317):

Honble. Sir, - I consider it an indispensable part of my duty to transmit for your information by an express prow the enclosed copy of a letter which I have just received from Captain D. Ross, commanding the Honourable Company's ship Discovery, containing intelligence of a very extraordinary and important tendency. As you are fully acquainted with the strength of the party at present doing duty here, I feel assured that you will adopt such measures as you conceive the nature of Captain Ross's report and the urgency of the present case may demand. In the meantime I have only to say that every thing here shall be held in readiness, as far as our means will admit, to resist any hostile attack on the part of the Batavian Government. We are at present much in need of a supply of money, and have no means of procuring any here.

" 420 noot 42. Bannerman antwoordde namelijk uit Poeloe Pinang dd. 16 Maart het volgende (Bg 317-318):

Sir, - I have the honour to acknowledge the receipt this day of your letter of the $6^{\text {th }}$ instant.

The intelligence you have thought it your duty to communicate to me, although very important, you must have been well aware could excite no surprise in my mind, in as much as you were personally and distinctly apprised by me before you quitted this island, that you were proceeding in an undertaking which was in violation of the orders of the Supreme Government, and which would expose you to a hostile attack from the Netherlanders.

I have now, therefore, to enclose for your information 
copies of two important letters lately received from the Supreme Government on the subject of the Dutch occupation of Rhio, and a copy of the correspondence which passed between Sir Stamford Raffles and myself after his arrival from Singapore.

Although it is not the province of this Government to furnish you with any instructions, yet a perusal of the enclosed documents may serve to guide your judgment, how far you will be justified in shedding blood in the maintenance of your post, and particularly after the communication made to the Netherlanders by the Chiefs of Johore and Singapore, which will certainly induce them to consider every resistance on your part as adding violence to injustice.

The Honourable Company's cruiser Nearchus and hired brig Ganges will afford your ample means for removing your party from Singapore in the event of such a measure becoming, in your judgment, proper and necessary; but I have distinctly to acquaint you that you must not expect any reinforcements from this Government until a reply is received from the Governor-General in Council, as it is the decided conviction of this Government that any force from this island could not oppose the overpowering armament at the disposal of the Batavian Government, and would only widen the breach which the late proceedings at Singapore have made between the British and Netherlandish authorities.

Another European officer, however, and a further supply of cash, equal to the payment of your detachment for two months, shall be forwarded by the very first opportunity.

I have also to acquaint you that your letter conveying the recantation of the chiefs of Johor and Singapore, as well as your present letter, shall be transmitted to the Supreme Government immediately.

In conclusion, I must beg particularly to apprise you that after the receipt of the present information respecting the views of the Governor-General and the sentiments of this Government, you will not be justified in the measure of shedding blood by pleading hereafter that your honour as a soldier compelled you to make resistance. As a soldier, I must unequivocally declare to you that your personal honour is in no degree implicated in the present occasion to render the shedding of blood necessary.

Bl. 420 noot 43. Ofschoon de correspondentie bij Boulger voorkomt, meende ik haar te moeten weergeven, daar toch 6e Volgr. V. 
vele lezers dezer Bijdragen in Indië het werk niet bij de hand zullen hebben en overigens de brieven voor de kenschetsing der treurige geschiedenis inderdaad te typisch mogen geacht worden. Bannerman's uitvoerige rapporten dd. 14 en 16 Maart 1819 naar Caleutta zijn ook zeer belangrijk ( $\mathrm{Bg}$. 320 vv.), doch wij zullen er den geest van kennen door onderstaand schrijven dd. 17 Maart 1819 aan onzen Gouverneur te Malakka (Bg. 316):

Information having reached me that the Netherlanders' Government of Java are, it is strongly believed, preparing to send up a force with orders to seize the English detachment posted at Singapore under the command of Major Farquhar, I conceive it is a duty I owe to you, as much as to myself, to apprise you immediately, that the whole subject respecting the occupation of that island was referred by me to the Most Noble the Governor-General on the $17^{\text {th }}$ ultimo, and that his Lordship's reply may be expected before the expiration of twenty or thirty days from this date.

Pending this reference therefore, motives of humanity, I hope you will allow, as well as the undoubted duty of preserving undisturbed the very friendly relations subsisting between our respective countries, call upon us to adopt ourselves and to recommend to the Netherlands Government of Java the same moderation and goodwill as have hitherto attended the transactions between your Government and mine. With this view I have a right to expect that you will join your best endeavours with mine in deprecating any such violent measure on the part of the Java Government as would lead to a cruel effusion of blood and excite a collision between Great Britain and Holland.

I am the more induced to make this appeal to you as Sir Stamford Raffles is not under the control of this Government, and I am really unacquainted with the nature of the reply he may have returned to your communication of the treaty existing between your Government and the kingdom of Rio, etc. -

Bl. 421 noot 44 . Bl. 221 mijner jongste verhandeling over Sumatra's Westkust (ov. 17).

" 421 noot 45. Dat de Engelsche bladen zich ook natuurlijk niet onbetuigd lieten, blijkt o, a. uit het Calcutta Journal van 19 Maart 1819, overgenomen door de Times van 7 September 1819 , waarin men het volgende leest: 


\section{Singapore.}

On the $4^{\text {th }}$ of February, I8I9, a treaty was concluded by the Honourable Sir Stamford Raffles, as Agent to the GovernorGeneral, with the Sultan of Johore, and the Tomongong of Singapore, in virtue of which the British flag has been planted on the ruins of the ancient capital of Singapore, where a Residency has been established under Major Farquhar, late in charge of Malacca.

This post seems admirably chosen with regard to geographical position, which, we have no doubt, will, in the course of a short period, give it very great commercial and political importance. It possesses the complete command of the Straits of Malacca and of Rhio, and is happily situated for the refitment, or if necessary the protection of our China- and Country-trade, the track of which is along the front of this settlement at the distance of only five-miles. The bay is well known to our eastern navigators, and a survey of it has lately been made by Captain Ross, of the Honourable Company's Marine, from which it appears, that it is easy of approach by day or night, free from all hidden danger, capacious, affording excellent anchorage, and well protected in all weathers. Good water is abundant and easely procured, as well as plentiful and cheap supplies of fish and turtle. The native population of the island is not numerous at present, but the industrious Chinese have already found their way into the interior, and in order to reap the riches of its produce, do not hesitate to undertake the labour of clearing the surface of a soil which cannot be surpassed in luxuriance by that of any of the Malay islands.

We believe and earnestly hope that the establishment of a settlement under such favourable circumstances, and at a moment when we had every reason to fear that the efforts of the Dutch had been successful in excluding us altogether from the Eastern Archipelago, will receive all the support which is necessary to its progress, and that by its rapid advance in wealth, industry and population, which in their establishment and development form the most honourable monuments of statesmen, it will attest hereafter the wisdom and foresight of the present administration, and its attention to the commercial and political interests of our country.

We congratulate our Eastern friends, and the commercial world in general, on the event which we this day report to them. They will rejoice in our having occupied the position 
which was required as a fulcrum for the support of our Easternand China-trade and from whence we can extend our commercial views and speculations. The spell of Dutch monopoly, so justly reviled and detested, and which had nearly been again established, has been dissolved by the ethereal touch of that wand which broke in pieces the confederacy that lately threatened our continental possessions; and while we are indebted to the noble ruler of these dominions for the peace an security of our homes, we have not the less reason to admire and applaud the extensive foresight by which another and a nearer link has been added to connect us with China, and by which our Eastern commerce has been secured.

Eenige dagen te voren, namelijk 1 Maart 1819, had resident Farquhar te Singapore ondervolgend officieel rapport gezonden aan den Algemeenen Secretaris te Calcutta (B):

As the Honourable Sir Thomas Raffles has no doubt transmitted through you to the most Noble the Governor-General in Council every requisite information relative to the Establishment formed by him on the Island of Singapore, I have at present only the honour to state that in pursuance of the instructions contained in your letter to my address under date the $28^{\text {th }}$ of November last, I assumed charge of the new settlement of Singapore on the $6^{\text {th }}$ Ultimo, since which period every thing has gone in the most prosperous manner. Inhabitants are flocking in from every quarter notwithstanding the very active and I may add oppressive measures which have been adopted by the Dutch Government of Malacca in order to put an entire stop to all intercourse with Singapore; indeed had the two nations been in a state of open warfare the restrictions imposed by the Dutch could scarcely have been more rigid than they are at present.

The climate here is, as far as we have yet experienced, extremely healthy and the settlement possesses every other advantage likely to render it a most flourishing colony.

In een door Farquhar gezonden rapport van 8 April 1819 leest men wijders (B):

It affords me the greatest satisfaction to be able to acquaint you for the information of the Most Noble the GovernorGeneral in Council that this settlement continues in population beyond my most sanguine expectations, and that it promises fair, if duly supported, to become a place of very considerable commercial as well as political importance. 
En Raffles zelf gaf uit Singapore dd. 22 Juni 1819 het volgende van geestdrift voor zijne stichting tintelend bericht (B):

I have the honour to report for the information of the Most Noble the Governor-General in Council that I arrived at this port on the thirty first ultimo on my way to Bencoolen.

The progress and success of the Establishment has in every respect been most satisfactory. The port has already become the general resort of the native trader, and the population of the place has encreased beyond my most sanguine expectations. The enclosed abstract of arrivals will shew that during the first three months, no less than one hundred and sixty seven vessels entered at the port of Singapore (exclusive of small prows from Rhio), upwards of a hundred of which arrived in one day and the population which has already accumulated under the protection of our flag is estimated to exceed five thousand souls.

The effect of this rapid influx of trade and population has been most sensibly felt in the abundance of provisions and supplies of every description, and in the facility of obtaining labour for every exigency of the Settlement.

His Lordship in Council will perceive from the enclosed report that these advantages have enabled Major Farquhar to carry into effect all the immediately important objects directed in my first instructions and to put the place in a respectable state of defence. In addition to the position first occupied by our Establishment, a considerable space has been cleared in every direction for the accomodation of the Native and European inhabitants as well as for military purposes; an extensive Chinese town has been marked out on the opposite side of the river, and the Bugguese have established themselves in consirable numbers on the margin of the Eastern bay, near which His Highness the Sultan has also fixed his residence. Ample space has been preserved in the most favourable situation for the cantonments etc., in front of which and on the sea-face batteries, calculated to mount twenty eight guns have been constructed. The old lines of Singapore extending from these batteries round the hill between fifteen and sixteen hundred yards in length have also been cleared of jungle and rendered partially defensible throughout.......(a)

(a) Volgen eenige alinea's over versterking der plaats. 
It is equally satisfactory to me to have it in my power to report that the most perfect harmony and confidence have continued to exist in our relations with his Highness the Sultan and Tummungung, of the warmth of whose attachment and devotion to our interests, which they justly consider identified with their own, I feel it difficult to express an adequate idea; of this and of the general confidence reposed in us, I cannot perhaps adduce a stronger proof than the unexampled encrease of the population and the eagerness with which settlers have crowded from all the neighbouring states.

But it is not merely in these and other local advantages that the effect of our establishment in these seas has been felt - it is my duty to bring to His Lordship's notice, the highly gratifying and satisfactory manner in which it has been hailed by the chiefs and people of the surrounding states, and the general impulse which it has given to that spirit of commercial enterprize and just independance, so essential to their prosperity and improvement, but which it was the policy of our rivals to subdue and repress. Not less remarkable has been the effect produced on the general tone and pretentions of the Dutch authorities, which in appearance at least, have become more moderate and consistent with the amicable relations subsisting between the two countries.

On my arrival at Singapore I found ambassadors and chiefs had arrived from most of the Malay States, conveying congratulations on our establishment and courting our alliance and protection.

From Tringano I found in the harbour one of the Sultan's vessels which His Highness had dispatched with rice and other suplies immediately on hearing of our establishment; this state is one of the most important on the Eastern side of the Peninsular and has hitherto escaped the influence of the Dutch; the Sultan and principal chiefs availed themselves of this occasion to express their anxious desire to cultivate a more intimate and closer connection with our Government. The same anxiety has been expressed on the part of the chief of Kalantan, a rising and flourishing state lying between Tringano and Siam. The people of these countries seem to consider the British alliance and protection essential to their interests and prosperity.

Communications had also been received from Cambodia, a country now subject to the general control of Cochin China, but under the immediate authority of a chief in close alliance 
and amity with the Sultan of this place with which there is a constant commercial intercourse.

From Borneo I found here an ambassador of rank and respectability specially deputed from Pontiana and who was also the bearer of communications from other states. From Siak one of the principal chiefs, nearly connected with the Government of Jambi, had waited several weeks for my arrival in the hopes of obtaining our consent to an establishment in that quarter, and an ambassador of rank brought letters to myself and Major Farquhar from the Sultan and other chiefs of Siak soliciting our protection.

From these and other sources of information it would appear that a feeling of reliance on the British Government is general throughout the Malay States, that such as are still free, look to our protection as the only means of preserving their independance, and those which have recently been compelled to submit to Dutch authority, look anxiously to an opportunity of relieving themselves from the restrictions with which their commerce has been fettered; so strongly does this disposition prevail in such of the Bornean States as have recently falled under this influence that the situation of the Dutch Establishments in that quarter appear to be extremely critical and to require either a national increase of force or an entire change of system.

Under these circumstances I felt it essential to be extremely cautious in my communications with the deputies of these States, in order to prevent the possibility of misconception as to our objects in forming an establishment at Singapore, or undue expectation of assistance or interference on our part - either in their own internal politics or in their relations with the Dutch Government.

I have therefore received these communications simply as marks of polite attention to the British Government, and have in consequence declined giving any answers whatever to the letter which have been delivered. I have endeavoured to preserve a due confidence in our Government, but have withheld any assurances or expectation that can in any way involve us beyond the immediate interests of the station we have occupied or lead to a departure from the principles and policy contemplated by His Lordship in it's establishment.

On the same principle and in the same spirit, have our more immediate relations with the states of Johor been conducted; and, although this cautious reserve on our part, 
instead of producing a corresponding policy on the part of the Dutch, may have enabled them to exert an influence over those States, prejudicial to the rights and interests of the legitimate authority, I am not aware that anything has occured in the smallest degree, affecting the original grounds on which our establishments was formed, and I feel confident that his Lordship will approve of the neutrality and moderation which has been uniformly observed.

I am aware that every exertion has been made by the Dutch authorities to obtain declarations and documents in favour of their own pretentions, and that they have not been very scrupulous in the means, but until I am made acquainted with the precise arguments which they may have thought proper to employ, I refrain from any attempt to meet them; it is proper however that in the meantime his Lordship should be acquainted with the general line of conduct they have been and are still pursuing, and the consequences that have resulted from their measures as far as they have come to my knowledge.

At Rhio every endeavour appears in the first instance to have been made to influence the Rajah Mooda to oppose our establishment, and it is asserted I have reason to believe with truth, that he was even called upon by the Governor of Malacca to make an attack on the place. In this object they failed and the Rajah Mooda having no inclination to commit himself to the British Goverment or to adopt the views of the Dutch, has since become so disgusted with their oppressive measures as to abandon the place and retire to Lingen; a special commissioner however (Captain Elout, son of the late first Commissioner General) has recently been sent from Batavia to Lingen for the purpose of inducing the Rajah Mooda to return to Rhio. In this object he has not yet succeeded and he has now come to Rhio, where in addition to the measures previously pursued, it is stated that the Dutch have occupied the Rajah Mooda's fort, and taken upon themselves the sole management of the place. $(a)$

(a) Volgens Netscher bl. 262-263 was de loop van de zaak des Onderkonings, genaamd Radja Djafar, aldus geweest. Krachtens art. 5 van het op bl. 404 vermeld contract van 26 November 1818 moest deze zorgen voor de voltooiing en het onderhoud van de aan te leggen fortificatiën te Riouw, verder dat een verblijf voor den resident en eene kazerne voor de militairen gebouwd werd, en dat aan het garnizoen, tegen redelijke betaling, hunne levensbenoodigdheden verstrekt werden. - De Onderkoning kwam niet alleen deze bepaling niet na, doch 
In order to strenghten their cause they have attempted to compel a public acknowledgement of the Rajah of Lingen as Sultan of Johore, and have even proceeded to the extremety of arresting and confining the persons of those who were unwilling to make this acknowledgement. This fact has been forced upon our attention by a representation made to us by the Tummungung in consequenee of the arrest of several persons of destination connected with this place, and I have the honour to enclose copie of the correspondence to which it has led, from which His lordship will perceive, that the native authority has been entirely superseded, and that such is the general feeling with regard to the proceedings of the Dutch that the place is likely to be soon deserted by its remaining inhabitants. (a) The Toonkoo Pootre alluded to

de inlandsche vorsten gingen voort de bevolking te knevelen en het beheer der inkomende en uitgaande rechten bleek aan groote moeielijkheden en onnauw. keurigheden blootgesteld. Om in een en ander verbetering aan te brengen, werd de kapitein C. P. J. Elout in 1819 naar de eilanden van Batavia in commissie gezonden; hij wist den Onderkoning te bewegen tot den geheelen afstand van de administratie der middelen, van welker opbrengst de helft aan het Inlandsch bestuur zou worden uitgekeerd, onder verzekering van een vastgesteld minimum; ons bestuur zou dan voor het opzetten van de bij art. 5 bedoelde gebouwen zorgen. De Onderkoning gevoelde zich echter vernederd door niet zelf het beheer over de inkomsten des lands in handen te hebben, waarom hij naar Linga uitweek en eene houding aannam, die den Gouverneur van Malakka aan de regeering te Batavia deed schrijven, dat Radja Djafar ten oorlog zich uitrustte.

Het gevolg was, dat de schout-bij-nacht Wolterbeek, die zich in de wateren van Palembang en Banka bevond, vergezeld van Elout, met de korvetten Venus en Galathea naar Linga en Riouw zich begaf en dd. 7 April 1820 eene nadere overeenkomst met den Onderkoning aanging.

(a) De correspondentie, waarvan de rede is, laat ik hieronder volgen (B). De resident Farquhar te Singapore ontving een schrijven van den Toemengoeng aldaar luidende:

„The following are the particulars of what has taken place with regard to the people of this place. I sent a vessel to bring stores belonging to me which were at Rhio. Information of this was given to the Shahbander of Rhio, who gave his permission and the articles were put into the vessel by my men. After this however the Dutch came and seized upon them, as well as five guns belonging to the Sultan (namelijk de sultan van Raffles) which were in the interior. They then called upon Intje Wan Saban, the brother of Intje Talib and Intje Wan Abdullah, the son of Toonkoo Hussman and asked the former: ${ }_{n}$ Which is the superior, the Rajah of Lingen or the Rajah of Singapore"'”; to which he replied: ${ }_{n}$ Truly the Rajah of Singapore is the superior, the Rajah of Lingen is inferior"'”. On this the Dutch said he had committed abuse and immediately placed him in confinement. They then asked Intje Wan Abdullah: " "Which do you follow the Rajah of Lingen or the Rajah of Singapore?”" to which he replied: „„They were the same to him, the Rajah of Lingen was a great man and so was the Rajah of Singapore"'". This the 
in the letter from Rajah Dris is the widow of the late Sultan Mohammed, in whose possession are the regalia of the Empire. Many attempts have been made (door de Nederlanders) to obtain them for the Rajah of Lingen (namelijk den Nederlandschen sultan) which have hitherto proved ineffectual. Her dispositions is understood to be favourable to the legitimate sovereign (hier wordt natuurlyk bedoeld de sultan van Raffles, toekoe Long), but unless she succeeds in carrying into effect her intention of quitting the place, it is possible she may compelled to enter into the vews of the Dutch. To prevent this his Highness the Sultan has repeatedly urged our concurrence in his proceeding to Rhio in person for the purpose of bringing her away, but apprehensive that such a measure might involve us with the Dutch, he has been persuaded to relinquish the idea, and has been satisfied with an opportunity, which we have had it in our power to afford him, of communicating with her and ascertaining her sentiments. $(a)$

Dutch said was also a crime and they seized and confined him likewise. This is what I wish to communicate." - Resident Farquhar interpelleerde over de inbeslagneming der goederen den Radja van Riouw of liever zijn vertegenwoordiger Radja Dris, „who is now the acting chief authority, the Raja Mooda having quitted the place some time for Lingen", berichtte Farquhar dd. 22 Juni 1819 aan Raffles. In dat zelfde bericht stond nog de volgende mededeeling: „Authentic information has been just received that the Dutch flag has been lately hoisted at the residence of the Rajah Mooda of Rhio in Poolo Pengingate." Radja Dris antwoordde aan Farquhar als volgt:

„Our friend's letter has been duly received, but with regard to the particulars to which it refers, we can assure him that we are utterly ignorant of them; we take no part in the proceedings of the Dutch at Tanjong Penang, for we ourselves have been placed in great fear as they wished to seize upon us also. On this account we know nothing of the affairs of either Intje Saban or Intje Wan; nevertheless let our friend enquire into them from the Dutch, for we know not of any fault, which they committed. We ourselves also wish to quit Rhio for we cannot bear with the Dutch rule. We send many compliments to our friend; let him not doubt what we say, no not in the least, as God may witness. It was not done with our knowledge. We have further half agreed with our sister Toonko Pootri, that both of us with all the Bugguese will quit this place, for they want to seize upon us. We send very many compliments to our friend Mr. Raffles." Inderdaad voeren de Boegineezen weldra naar Singapore over!

(a) Tongkoe Poetri had geweigerd de Rijkssieraden af te geven. Sultan Abd'oerrahman (onze vorst van Riouw), spijtig over het gemis der voor hem als oppervorst onmisbare teekenen zijner waardigheid, begaf zich in 1821 van Linga naar Trenganoe, met het plan om niet terug te keeren, zoolang de rijkssieraden niet in zijne handen waren gesteld. Doch ook Sultan Hoesin (Toekoe Long, de sultan van Raffles) deed, op last van het Engelsch bestuur, vele pogingen om Tongkoe Poetri tot de afgifte dezer insignia aan hem te bewegen, en men beweert zelfs, dat haar daarvoor 50.000 Spaansche matten was geboden. 
With Lingen we have of course avoid all direct communication, but with Pahang a close and friendly intercourse has subsisted. The chief of this place is Bandahara of the Empire and from his rank in the State and vicinity to our establishment it is of importance to maintain that good unterstanding; we early received an intimation from him of his desire to visit Singapore, which he probably would have done 'ere this had the Moonsoon permitted. Since my arrival here however, information has been received of measures of intimidation having been pursued by the Dutch with the view of interrupting this intercourse and compelling him to enter into their views and policy. In consequence of this I have thought it adviseable to depute Mr. Garling, a civilian of some experience on the Bencoolen establishment, who had been provisionally detained at this settlement, to proceed to Pahang for the purpose of counteracting these attempts as far as may be practicable without involving the risk of collision. (a)

In concluding this dispatch I should be wanting in my public duty, did I not on a most particular manner express to his Lordship my acknowledgements to Major Farquhar

Toen de Onderkoning Radja Djafar dit bemerkte, riep hij de hulp van ons bestuur te Batavia in. Dientengevolge kreeg de Gouverneur van Malakka last de noodige stappen voor de afgifte te verrichten. Hierin slaagde hij dd. 13 October 1822; de rijkssieraden werden vervolgens in het fort te Tandjong Pinang in bewaring gesteld. De Gouverneur gaf onmiddellijk den Sultan Abd'oerrahman kennis, dat de insignia te zijner beschikking waren met dringend verzoek om, vergezeld van den bandahara van Pahang, zoo spoedig mogelijk naar Riouw over te komen. Noode gaf hij hieraan gevolg en wel eerst dd. 3 November 1823, vergezeld van den Onderkoning, terwijl de plechtige uitreiking den $27 \mathrm{~d}$. a. v. plaats vond; de bandara van Pahang had zich daarbij laten vertegenwoordigen. Netscher; bl. 276-278.

In Crawfurds correspondentie met het bestuur te Bengalen wordt, vermoedelijk niet zonder opzet, gerapporteerd: „The Dutch Commissioners, while at Malacca, invited the rival brother of the Sultan, who is connected with us, to come round to Rhio from Tringano, where he had been residing for several years, and sent a ship of war for his accomodation. This invitation was accepted, and about the end of October the Native Prince in question arrived at Rhio, where he was put in possession of what are called the Regalia and raised to the throne of Johore." De door Crawfurd vermelde rival brother was nota bene reeds in 1812 ten troon verheven en Farquhar had zelfs met hem, gelijk wij weten, een tractaat gesloten! Doch nu de Engelschen diens broeder als sultan noodig hadden, die hun Singapore had afgestaan, wilden $\mathrm{zij}$ het doen voorkomen, of wij eerst na dien afstand den mededingenden broeder op den troon van Djohor hadden gebracht!!

(a) Volgens Netscher bl. 278 noot (1) had de Bandahara van Pahang in 1819 geweigerd, dat de Engelschen hun vlag heschen te Pahang en bij die gelegenheid, in een brief van 20 Juli, zijn trouw aan onzen Sultan Abd'oerrahman verzekerd. Uit sub 54 zien wij, dat Raffles over Garling's zending naar Pahang berispt is geworden. 
for the zealous co-operation and essential assistance which I have received from him throughout, and my conviction that the interests of this rising settlement could not have been entrusted to abler or better hands.

Bl. 421 noot 46. De opmerking komt voor in $\S 23$ der sub 65 weder te geven missive dd. 17 Juni 1820 , gericht aan het bestuur te Londen, waarin o. a. Engelsche afschriften van den sub 57 mede te deelen brief dd. 16 December 1819 en bijlagen van onzen Gouv.-Gen. en het daarop door Calcutta gegeven antwoord worden overgelegd. Raffles had een paar dagen te voren eene geheel gelijke opmerking gemaakt; zie bl. 474 al. 2 .

" 422 noot 47. De mededeeling dd. 18 Maart 1819 bij V. D. bl. 281.

" 422 noot 48. De verzekering van 22 September 1819 in de op bl. 405 vermelde dissertatie van Spengler bl. 96 .

" 123 noot 49. "Notice" van De Grovestins (1852) bl. 497.

" 424 noot 50. De brief van onzen Gouv. Gen. dd. 25 Februari 1819 aan den Gouv. Gen. van Bengalen komt in B's verzameling in het Engelsch voor. Men treft echter in onze eigen archieven het oorspronkelijke stuk aan; het luidt aldus:

Il m'est extrêmement pénible de me voir de nouveau forcé, à porter des plaintes contre les procédés de deux fonctionaires Britanniques, dépendants de votre Excellence.

J'en éprouve une peine d'autant plus vive, que je partage de la manière la plus cordiale les sentiments de bienveillance et d'amitié, qui animent si sincèrement nos Gouvernements respectifs, et que la parfaite estime et la haute consideration que je porte à Votre Excellence personnellement, me font vivement désirer de n'avoir à traiter avec Elle, que de sujets analogues à ces relations, qu'il m'est si agréable de cultiver.

Le Gouverneur de Malacca vient de m'informer: qu'une force armée dirigée par le major Farquhar et le chevalier Raffles est venue se présenter à Rio, afin de réclamer du Vice-Roi une cession de territoire en vertu d'un traité conclu au mois d'Août dernier, avec le major Farquhar, alors résident de Malacca; que le Vice-Roi a déclaré, que par suite de la remise de Malacca au Gouvernement Néerlandais, et par les stipulations d'un traité subséquemment conclu entre le Roi de Rio, Linga, Johor et Pahang et le contre-amiral Wolterbeek, au nom du Gouvenement Néerlandais au mois de Novembre dernier, il devait se considérer comme vassal 
du Gouvernement Néerlandais; et que, comme tel, il était obligé de refuser la cession exigée de lui, le traité susmentionné renouvellant les principaux articles de celui de 1784 , et abrogeant expressement tous les autres traités, qui auraient pu avoir été conclus.

Qu'après cette déclaration la force Anglaise a précipitamment quitté Rio, et s'est rendu à l'isle de Singapoor, dont elle a pris possession par voie de fait, en y arborant le drapeau Anglais, et qu'enfin le Gouverneur de Malacca s'est hâté d'informer le chevalier Raffles, que cette isle, faisant partie du royaume de Rio, Linga, Johor et Pahang, était une dépendance de son Gouvernement, lui envoyant par la même occasion un extrait du traité, récemment conclu, par lequel cet état de choses est parfaitement avéré, et protestant en même temps formellement contre cet acte à la fois illégal et violent du chevalier Raffles et de ceux qui l'accompagnent.

J'ignore, mylord, quel a été le resultat de cette protestation, mais j'ose espérer qu'elle aura eu l'effet désiré, et que la communication officielle de la relation, existant entre les états de Rio, Linga, Johor et Pahang et le Gouvernement de Malacca, aura été pour les fonctionnaires Britanniques, un motif suffisant pour leur faire abandonner une entreprise, qui ne pouvait se consommer sans une violation manifeste d'un territoire dépendant de sa Majesté mon auguste Souverain.

Afin de mettre votre Excellence à même de juger de la légitimité de nos réclamations, j'ai l'honneur de lui faire parvenir sous ce pli, une copie du Traité susmentionné, conclu entre le contre-amiral Wolterbeek et le sultan Abdul Rachman Sjah, roi de Johor, Pahang, Rio, Linga et dépendances et de demander son attention particulière, sur la version suivante des articles 22 et 23 de cet acte,

ART. 22.

Vu que le présent traité est entièrement conclu à la satisfaction des parties contractantes, et que la haute Régence $(a)$ s'y engage à protéger les états de Johor, Pahang, Rio, Linga et dépendances, le Sultan promet de son côté de conserver l'intégrité de son royaume, de n'en jamais céder aucune partie, à aucune autre puissance sans l'approbation de la haute Régence, et de ne conclure aucun traité avec une autre nation quelconque, sans l'assentiment de la dite Régence.

ART. 23.

Par le présent acte, qui sera le seul en force, tous traités antérieurs sont déclarés être abrogés, etc.

(a) Overbodig te herinneren, dat la haute Régence de vertaling is van "de hooge Regeering". 
Après la lecture de ce dernier article, votre Excellence partagera sans doute mon opinion, que s'il pouvait exister encore le moindre doute, par rapport à la faculté du Gouvernement Britannique de se prévaloir, après la remise de Malacca, d'un traité conclu par le major Farquhar, remplissant les fonctions de résident de cette place, avec un prince Indien, qui en dépendait, ce que je suis cependant loin de croire; - ce doute doit cesser entièrement par la déclaration spontanée et formelle de ce Prince, par laquelle il reconnait d'une manière non équivoque la transition de cette dépendance, sous la puissance, qui possède actuellement Malacca, transition qui d'ailleurs était une conséquence directe et naturelle de la remise de cette place, et qui devrait être reconnue comme telle, même sans l'aveu du vassal, dont-il s'agit ici.

Il est une circonstance qui pourrait paraître au premier abord porter atteinte à la justesse de ce raisonnement, c'est l'acte, que c'est permis en I795, le Gouverneur de Malacca, le sieur A. Couperus. Cet acte est peut-être inconnu à votre Excellence; Ia franchise, dont je désire en agir avec Elle, m'engage à lui en donner les détails $(a)$.

En I795, la haute Régence, agissant au nom de la Compagnie des Indes, parait avoir songé un moment à la suppression de ses établissements militaires dans les états de Johor, Pahang, Rio et Linga, moyennant une somme assez considérable, que le Sultan devait s'engager à payer, et sous condition encore de conclure avec la Compagnie un nouveau traité.

Le sieur Couperus, de concert avec les autorités Britanniques, se trouvant à cette époque à Malacca, et outrepassant les instructions qui lui avaient été donnés, s'est permis à retirer la garnison, et les fonctionnaires qui étaient à Rio, sans requérir le Sultan de satisfaire à la condition éventuelle qui lui était imposée.

Toutefois cependant cet acte n'a jamais été approuvé par la haute Régence, qui seule pouvait le rendre valide, et dès lors il est clair: que les états de Johor, Pahang, Rio et Linga n'ont jamais cessé de former partie des dépendances de Malacca; que l'effet du traité de 1784 , réglant les relations

(a) Volstrekt alweder niet franchise. Uit het op bl. 410 medegedeelde blijkt, dat de Engelschen in het bezit waren van de hierbedoelde Couperus-stukken. Gouv.-Gen. Van den Capellen wilde dus bij voorbaat de argumenten bestrijden, die de Britsch-Indische regeering daaruit zou weten te ontleenen; anders had hij er natuurlijk wel over gezwegen! 
entre le dit Royaume et le Gouvernement Néerlandais n'a été suspendu que par la guerre survenue entre les puissances Européennes; et que la remise de Malacca, stipulée par nos Gouvernements respectifs a nécessairement rétabli le status ante bellum, pour autant qu'il n'y a pas été expressement dérogé par le traité de 1814 et a par conséquent fait revivre tacitement les stipulations du traité de 1784 , renouvellé par celui du 26 Novembre 1818 .

Les contracts par contre, que le major Farquhar pourrait avoir conclu avec les. chefs de ces états, dépendant de Malacca, peu de semaines avant la remise de cet établissement, ne peuvent point être considérés comme valides après cette remise, ni dérogé en aucune manière aux droits du Gouvernement Néerlandais.

Il me reste encore à parler d'un fait qui m'est communiqué dans les dépêches du Gouverneur de Malacca, et qui est si directement opposé à cet esprit de loyauté, qui marque toutes les mesures de votre Excellence, et de la nation dont elle dirige si glorieusement les affaires dans les Indes, que je suis persuadé, qu'il suffira de le signaler 'à votre Excellence pour qu'Elle le désapprouve indépendamment de la question principale dont il s'agit. Il parait que le chevalier Raffles et le major Farquhar sont accompagnés d'un certain Toekoelon, frère du Sultan règnant de Linga etc., et prétendent au trône que celui-ci occupe depuis plusieurs années. La présence d'un chef mécontent, faisant des prétentions au trône, environné d'un appareil de force, et soutenu par des fonctionnaires Britanniques, pourrait avoir des suites fâcheuses, et donne en tout cas à ces fonctionnaires l'apparence de vouloir fomenter le trouble et la discorde.

Engagé par un traité solemnel à protéger les états de Johor, Pahang, Rio et Linga, le Gouvernement Néerlandais ne peut que vivement s'intéresser à tout ce qui pourrait affecter la tranquillité de ce Royaume, et croit pouvoir attendre de la part d'un Gouvernement juste et loyal la repression immédiate de pareils moyens, dont des agents subalternes pourraient s'être permis d'avoir fait usage.

$\mathrm{Je}$ me repose avec une entière confiance sur les mesures que votre Excellence prendra sans doute, en conséquence des représentations qui font le sujet de cette dépêche.

Bl. 4,24 noot 51. Het bestuur te Londen wees den Gouv.-Gen. van Bengalen in den sub 62 mede te deelen brief dd. 8 Augustus 1820 op die vergissing. 
Bl. 424 noot 52. De brief dd. 26 Juni 1819 van het bestuur te Calcutta (geteekend Hastings, G. Dowdeswell, J. Stuart, J. Adam), die in onze archieven ligt, doch ook in B's verzameling werd opgenomen, luidt aldus:

We have had the honour of receiving your Excellency's despatch of the $25^{\text {th }}$ February, relating to the occupation of a post at Singapoor by a British detachment acting under the orders of Sir Thomas Stamford Raffles.

2. Before we state to your Excellency the result of our deliberations on your Excellency's communication, we will explain in the most frank and open manner the circumstances which have lead to the measure against which your Excellency is pleased to remonstrate.

3. The spirit of aggrandizement, evinced in the proceedings of the Commissioners-General of His Netherlandish Majesty, and their manifest endeavours to establish the absolute supremacy of the Netherlands in the Eastern seas, made it necessary for us to adopt precautions with a view to avert the injury and degradation, which could not fail to ensue from a listless submission to the unbounded pretentions displayed on the part of your nation.

4. That our views relative to those seas have ever been confined to the security of our own commerce, combined with the freedom of that of other nations, is a position which does not need demonstration. Its undeniable truth is shown by the whole series of our conduct in the Eastern seas, during the period, when our power in that quarter was unrivalled and unassailable. We might then without difficulty have made arrangements for the establishment of our supremacy and might have stipulated for the preservation of those arrangements at the general peace of Europe. Instead of which we shunned the ready means of aggrandizement and restored to your nation its noble colonies, without having made any step towards the increase of our own power, during the long interval in which no nation of any quarter of the globe could have impeded its extension. $(a)$

(a) De voorstelling is niet volkomen juist. Afgescheiden van beperkende maatregelen, had men in den Archipel destijds geene mededinging te vreezen. Het is de oude humbug van free trade, wanneer men alleen kan zijn, doch ingekrompen tot fair trade, wanneer ernstige mededingers zich vertoonen. Hoe vriendelijk men jegens ons was in V6ór-Indië is genoeg bekend. Dat geene vergrooting van gebied in het plan lag, was ook niet juist: adres aan de geschiedenis van Banka en onderhoorigheden en de contracten met Bandjer. 
5. In restoring your colonies with unlimited confidence and without any literal restriction, we had not to expect that you would assume as restored what we never received from you, and never occupied ourselves. We little thought that some of the first acts of your Government after the restitution would be to reduce to vassalage the states, which we had treated as perfectly independent, and to impose treaties on those states, having for one of their principal objects the exclusion of our commerce from all ports, except when admitted by your permission.

6. Your Excellency will not, we are sure, be surprised that the development of such a policy, so opposite to that which we had pursued in the Eastern seas, should excite our anxiety for the safety of our commerce, and induce us to turn our thoughts to the means of preserving it.

7. With this view, after the designs of the Netherlandish authorities had become unambigously manifest, we were desirous of forming precautionary engagements with the independant governments of Rhio, Lingin and Johor; and for the execution of this purpose a mission was deputed under sir T. S. Raffles, to be assisted by major Farquhar, who were both selected tor that duty from their intimate knowledge of the affairs of the Eastern archipelago.

8. So anxious were we at the same time to avoid the least collision with the Netherlandish authorities, that we directed sir T. S. Raffles to abstain from further intercourse with Rhio, should he find any post established there on your part; though our previous treaty with that state gave us a right to consider ourselves as already connected with it.

9. In the same spirit we warned sir T. S. Raffles that, even in the event of your having extended your claims over the whole of the ancient kingdom of Johor, refutable as we should conceive such pretensions to be, we were not disposed to incur the probability of clashing with the Netherlandish government in India on that question, but should reserve it for the decision of our respective gouvernements in Europe.

I0. Sir T. S. Raffles, on his arrival at Prince of Wales' island, found that the agents of your nation had anticipated him at Rhio. He therefore very properly avoided that port.

I I. He proceeded to Singapoor and there formed a treaty, with a chief, whom he describes as the rightful sovereign of Johor, as well as with the local Government, which he represents as being independent of that established at Rhio. A copy 
of the treaty is annexed for your Excellency's information. I2. Sir T. S. Raffles has not sufficiently explained to us why he proceeded to Singapoor, after learning the extent of the pretensions advanced by your agents at Malacca. A strict attention to our instructions would have induced him to avoid the possibility of collision with the Netherlandish authorities on any point. And so sincere is our desire to bar the possibility of any altercations with your Excellency's Government that the occupation of Singapoor has been to us a source of unfeigned regret.

13. In fact, after becoming acquainted with the extent of the pretensions advanced on the part of your nation, and before we knew of the establishment of a factory at Singapoor, we had issued instructions to sir T.S. Raffles directing him, if our orders should arrive in time, to desist from every attempt to form a British establishment in the Eastern archipelago.

14. These orders did not however arrive early enough to prevent the establishment of a factory at Singapoor; and the question for our consideration now is, whether we shall maintain the establishment, which has been formed, or carry a complimentary deference for the Netherlandish authorities so far as to withdraw it.

I5. We flatter ourselves that your Excellency's candour will at a single glance perceive the difficulty in which we are placed, as well as the wide difference between that state of circumstances in which we should have been at liberty to indulge our solicitude to shun any apparent discordance with your Government, and the case now before us in consequence of the actual establishment of a factory at Singapoor.

I6. That solicitude did not proceed from any admission of grounds for the exorbitant pretensions which the proceedings of your Government and the language of your agents had manifested. It proceeded from an earnest wish to prevent any interruption of cordiality and harmony of sentiment between the local governments in India, pending the decision which we had reason to expect from our respective governments in Europe.

17. But that which we were so studious to avoid, has now perversely occured: we find ourselves established by treaty with the native government on a spot from which your Excellency asserts a right to exclude us. We cannot relinquish our possession on your demand without subscribing to the right which you claim, and of which we are not satisfied; 
thereby awckwardly forestalling the judgment, which must have taken place at home.

I8. By the same act we should sacrifice the interests of those who have entered into engagements with us, injure our own reputation by such a sacrifice and justly suffer irretrievable loss of influence through so inexplicable a proceeding.

I9. Let us be convinced that, in establishing a factory at Singapoor, we have intruded on any right possessed by your nation or any claim which we are bound in equity to respect. In this case we should immediately withdraw our establishment from Singapoor, fully recognising your title to expect that course of conduct from us.

20. On this point we at present entertain the strongest doubts, which we proceed to explain most frankly to your Excellency, in order that your Excellency may favour us, if it be in your power, with such proofs and arguments as may tend to remove them.

21. Your Excellency claims Rhio, Johor, Pahang and Lingin as dependencies of Malacca. But, when our Government was established at Malacca, the Dutch authorities at that place, in pursuance of the declared intentions of their superiors, the government of Batavia, had withdrawn their establishments from Rhio, the only post in their occupation and declared the independence of the chief of that country. On the strength of that public and conclusive transaction we have always considered and treated Rhio as an independent state, and never exercised over it any act of supremacy.

22. When we restored Malacca to you, we could not restore that which we dit not receive from you. We did not restore Rhio, Johor, Lingin and Pahang as dependencies of Malacca, because (not having obtained them from you) we did not possess them as such. (a) We restored to you what was transferred to us in 1795 and nothing more. That transfer did not include Rhio, Johor, Lingin and Pahang, and this seems to be admitted in your Excellency's letter to which we have now the honour to repley.

23. Under these circumstances we do not conceive that your Excellency can justly appeal to any connections, whatever they may have been, which may have existed before I795, but which were not included in the transfer made to us in that year.

(a) Er had nog bijgevoegd kunnen worden: daarom hebben wij ook geweigerd Bandjermasin $u$ over te geven; verg. mijn Bandjermasin-artikel: Bijdragen dl. XLIX (1898) bl. 18 vv. en bl. 46 vv. 
24. Such connections were abrogated by the official acts of the representatives of your country on that occasion. We did not reap the advantage to which we should have been entitled, if those connections had then been declared to be in existence; and the subtraction of those advantages from us, had there been a title to them, would have been a fraud of which your nation was wholly incapable; and we flatter ourselves that your Excellency will thence not deem it reasonable to call upon us now to recognise connections, which to us seem gratuitously supposed for the special purpose of effecting the aggrandisement of a foreign government at our expense.

25. If, as we hold to be case, you have no just claim founded on engagements, which may have existed before the transfer of Malacca in I795, your only right depends on the treaty concluded at Rhio on the $26^{\text {th }}$ November 1818 .

26. This treaty was subsequent to the one settled by major Farquhar on the part of the British government with the government of Batavia in the August preceding.

27. Major Farquhar's treaty was settled with the government of Rhio, not as a dependency of Malacca, but as an independent state, purposely with a view to the validity and value of the connection, after the restoration of Malacca to your nation.

28. The treaty subsequently entered into by your agents at Rhio, declares the treaty previously concluded on the part of the British government to be null and void. The conciliatory spirit in which we sought to avoid all differences here, and to leave all points to adjustment at home, is sufficiently proved by our not having remonstrated against this most extraordinary and injurious proceeding. (a)

29. If our previous treaty which contained nothing injurious to any foreign nation, was not entitled to respect from your nation, we know not by what reason your Excellency can expect us to acknowledge and respect your subsequent treaty, tending manifestly to our injury and annulling engagements previously existing between the state of Rhio and our Government.

30. The only rights of possession in the Eastern archipelago, which we are bound to acknowledge as vested in the

(a) Wolterbeek zou inderdaad groot politiek doorzicht getoond hebben, indien hij Farquhar's contract niet zoo volstrekt had vernietigd, doch de betrekkelijk weinig beduidende voorrechten had erkend, die nu eenmaal door sultan Abdoerahman waren toegestaan. Gelijk ik reeds mededeelde vindt men Farquhar's contract o. a. bij Netscher, bl. 252. 
Netherlandish nation, are derived from the convention of the $I 3^{\text {th }}$ Augustus 1814 , between our respective sovereigns, in which it was settled that we should restore, with certain exceptions, the colonies, factories and establishments possessed by Holland on the $\mathrm{I}^{\text {st }}$ January 1803 .

3I. The possessions to be restored under this convention are of two descriptions. Those which were actually in the possession of Holland on the $\mathrm{I}^{\text {st }}$ January $\mathrm{I}^{80} 3$, and had been captured by us between that time and the general peace. And those which, though restored at the peace of Amiens, had not actually been occupied by Holland before the renewal of hostilities in 1803 .

32. With regard to either description we engage to restore such colonies and dependencies as actually came into our possession at the respective periods of acquisition.

33. Java was in the possession of Holland on the $I^{\text {st }}$ January 1803 . When Java came into our possession the only dependencies beyond the island attached to that Government, were the residencies of Macassar on Celebes, and Copang on Timor, and the factories at Palembang and Japan, and these only are we bound to acknowledge as the proper dependencies of Java reverting to your Sovereign with that colony by the convention of August I8I4. When your Excellency carries your pretentions further, as we have a deep interest, so we possess an indisputable right to examine into their foundations.

34. Malacca was not actually in the -occupation of Holland on the $\mathrm{I}^{\text {ste }}$ January $\mathrm{I} 8 \mathrm{O} 3$; but has nevertheless been restored with the only dependency which came into our hands along with that settlement.

35. According to this interpretation, if we had received Singapoor as a dependency of Malacca in 1795, if at that time the Dutch authorities had made over to us any factories or establishments of any kind at Singapoor, if they had even asserted an acknowledged right to that place as a dependency, we should now, notwithstanding the lapse of so many years during which it has been independent, be disposed to recognise your claim. But the Dutch authorities which transferred Malacca in 1795 declared that Rhio and Johor, Pahang and Lingin, through the first of which you claim Singapoor, were not dependencies of Malacca.

36. We observe in the letter of your Excellency, to which we have now the honour of replying, that you are disposed 
to argue that the withdrawing of the Dutch establishments from the states of Johor, Pahang, Rhio and Lingin, and the declaration by the Dutch authorities at Malacca of the independence of those states, were measures not approved by the constituted authorities of the Dutch East India Company.

37. We entreat your Excellency to consider that, supposing this to have been precisely as stated to your Excellency, we were nevertheless acting under those declarations, which were to us authentic and sufficient during twenty three years of possession, throughout which time not a single effect was made to undeceive us, either in war or peace. We flatter ourselves that on reflection your Excellency will see the injustice of expecting us to acknowledge such claims after so long an interval of disuse and so decided an abrogation of them.

38. For the reasons which we have mentioned, it behoves us to pause before we sacrifice our own interests and those of the chiefs who have connected themselves with us, in order to yield to those vast pretensions which at present we hold to be unjust and untenable.

39. If we could agree to consider Rhio as a dependency of Malacca, it would still remain to be shown that Singapoor is a dependency of Rhio, or of the principality of which the Government resides at Rhio.

40. This brings us to the point whether the chiefs who made treaties with us at Singapoor were competent to make those treaties.

41. Those chiefs are represented to us as being perfectly independent of the chiefs, established at Lingin and Rhio, and fully competent to make engagements with respect to Singapoor and the territory under their Government.

42. We expect further information on this subject, by which our decision respecting Singapoor may be materially guided.

43. In the meantime we have the honour to enclose a statement of the information already received, which makes it appear that the chiefs at Singapoor are independent of those at Rhio and Lingin; and which directly contradicts the representation made to your Excellency, that some adventurer, named Tookoelon, had been brought forward as a pretender to the throne in order to sanction the procedure of sir S. Raffles.

44. We now proceed with the same frankness, which we flatter ourselves your Excellency will perceive throughout our 
communications, to apprise you of our present intentions with respect to the new establishment at Singapoor.

45. We shall endeavour to ascertain to our own satisfaction whether or not the Netherlandish nation posesses a right to the exclusive occupation of Singapoor, and if that point be decided in the affirmative, we shall without hesitation obey the dictates of justice by withdrawing all our establishments from that place. We most cordially invite your Excellency to furnish us with proofs of the justness of your pretensions. We do not seek any advantage, which is not supported by truth and equity, and we shall really feel indebted to your Excellency for putting us right, if we have erred in the view which we have taken of this question.

46. In like manner we shall endeavour to ascertain whether or not the chiefs of Singapoor with whom sir T. S. Raffles has concluded engagements, possessed a right to enter into those engagements; and if it should appear that the right of the government of Lingin or that of Rhio, or of any other native power, has been violated, our respect for the rights of every power will induce us instantly to abandon Singapoor, on the requisition of the injured power.

47. But this is a distinct question, in which we do not acknowledge that your Excellency's government is any wise concerned, and we only mention it in order that your Excellency may be fully apprised of our views.

48. If the result of our enquiries and deliberations be to confirm our present apprehensions, and to convince us that the Netherlandish nation has not any right to exclude us from Singapoor, and that the persons who have signed the treaty with us are the legitimate rulers of the country, we must in this case hold Singapoor, till we know the result of the reference which we have made to Europe, as we have already had the honour of intimating to your Excellency.

49. The result of that reference, we trust, will be either to define the respective limits of the rights and power of the Netherlandish and British nations in the Eastern archipelago, or to establish a liberal and friendly policy for the guidance of the local governments on a footing of cordiality, equality and reciprocal benefit.

50. Before we conclude this dispatch, we beg leave to call your Excellency's attention to a few general observations.

51. The proceedings of the Netherlandish authorities, since the arrival of the Commissioners, empowered by your august 
Sovereign to receive charge of His Majesty's possessions in the East Indies, have created a strong impression on our minds, that those proceedings have been actuated by a spirit of ambition, by views of boundless aggrandisement; and especially by a desire to obtain the power of monopolising the commerce of the Eastern archipelago, and of excluding us from these advantages which we have long enjoyed, and which we only wish to share in common with the other nations of the earth.

52. If your Excellency should enquire what acts in particular have made the impression we describe, we deem it sufficient to specify two striking examples of the tone and tendency of the whole, without adverting anew to former subjects of complaint.

53. We beg leave to refer your Excellency to the language addressed by your agent at Pontiana to major Farquhar, requiring the latter to refrain from attempting to form any connection with any of the chiefs of Borneo, on the ground that the whole of that country had come under your control. In a similar manner you now claim the right of excluding us from all the countries of Johor, Pahang, Rhio and Lingin.

54. We are satisfied that the ministers of our Sovereign in Europe never contemplated the possibility of such pretensions when they signed the Deed, restoring the colonies of your nation in the Eastern seas.

55. We leave it to your Excellency to imagine what sensations such a course of procedure on your part must excite in the minds of a commercial nation, which, if it could submit to such encroachements, would find its trade in the Eastern archipelago placed at your mercy, and how much those sensations must be aggravated by the recollection of the intimate friendship existing between our respective sovereigns.

56. Compare the treaties recently concluded on the part of your nation with native princes, with those which were concluded on our part under the direction of the government of Prince of Wales' island. In these your Excellency will observe that the utmost we stipulated for is, that our vessels should be received on the same footing with those of the most favoured nations. There was no attempt to obtain the power of excluding the vessels of other states, no endeavour to establish our supremacy by making the native states subscribe to an acknowledgment of vassallage.

57. The measures pursued by the Netherlandish govern- 
ment since its re-establishment in the Eastern archipelago leave us only the choice of one of three modes of acting. To submit implicitly to all your pretensions, which our interests and our honour alike forbid. To oppose them by systematic courter-action and resistance, which friendship and courtesy prohibit. Or to refer all questions for the decision of our respective governments in Europe, which is the course we have adopted.

58. We trust that the former acts of our Gouvernment in connection with the proceedings of the Netherlandish authorities must have satisfied your Excellency not only of our inviolable determination to do justice in every instance, but also of our disposition to yield more than could be justly demanded of us for the sake of that amity and cordiality which we wish to preserve with your Excellency's Government; but if we were to acknowledge the enormous pretensions set up on your part, we know not where they would stop, nor to what degree of self-exclusion and degradation we should be required to submit.

59. On the other hand, if we were to imitate the policy acted on by the Netherlandish authorities and seek to obtain exclusive privileges in the numerous ports and countries of the Eastern archipelago, we entreat your Excellency to reflect on the probable consequences of the continual collision of interests and disputes of subordinate authorities which would unavoidably ensue.

6o. We trust, therefore, that your Excellency will concur in our view of the expediency of mutual forbearance until we receive the orders which our respective governments in Europe may be expected to transmit for the future regulation of our relative policy and respective possessions and connections in the Eastern archipelago.

6r. We consider it due to your Excellency to put you in possession of the accompanying copies of documents received from sir T. S. Raffles and major Farquhar, relating to declarations said to have been made by the Toomengoong of Singapoor to a Dutch gentleman at Malacca and the native authority of Rhio.

Bl. 424 noot 53. De brief dd. 25 Maart 1819 van onzen Gouv.Geu. aan Bengalen luidde aldus:

J'ai eu l'honneur d'entretenir votre Excellence dans ma lettre du 25 Février sur les événements, qui avaient eu lieu dans les environs de Malacca, pour autant qu'ils m'étaient connus alors. 
Je viens de recevoir en conseil de nouvelles dépêches du Gouverneur de cet établissement, qui m'apprennent des détails, dont je ne portais pas encore connaissance, et dont je suis obligé d'informer votre Excellence.

Ce que je viens d'apprendre, confirme ce que j'avais prévu, que le chevalier Raffles, voyant ses projets sur Palembang et les Lampongs échoués, par les mesures de votre Excellence, se hâterait de lancer dans une autre partie de ces paisibles contrées le brandon de discorde, qui paraît le guider partout où il porte ses pas.

Je tâcherai de réprimer le sentiment d'indignation qui m'anime, en rendant compte à votre Excellence de la conduite irréfléchie de cet homme turbulant et de la trame qu'il est occupé d'ourdir.

J'ai déjà parlé à votre Excellence d'un prince Indien, frère du sultan de Linga, Riouw, Pahang, Johor etc., que le chevalier Raffles et le major Farquhar trainaient à leur suite dans l'expédition, qui avait pour but la prise de possession de l'isle de Singapore, l'une des dépendances du Gouvernement de Malacca.

J'étais loin cependant de supposer encore que le chevalier Raffles se permettrait des démarches aussi illégales, je dirais presque aussi absurdes, que le sont celles dont il rend compte lui-même au Gouverneur de Malacca, dans la lettre dont j'ai l'honneur de joindre une copie à celle-ci $(a)$.

Il lui communique avoir conclu un traité et une alliance défensive, au nom de votre Excellence avec les sultans Hussin Mahummed Sjah (le même Toekoelon, nommé dans ma précédente du 25 Février dernier) fils aîné et héritier légitime et successeur du feu sultan Mahummed Sjah, et avec Datoe Tummenggoeng Sri Maharadjah Abdul Rahman, toemengoeng de la division de l'empire, nommé Johor propre; qu'en vertu des stipulations de ce traité une factorie Anglaise avait été établie à Singapore, que le port et l'isle de ce nom avaient été placés sous la protection du pavillon Britannique; que cependant les vues de ce Gouvernement n'étant que purement commerciales, et lui, chevalier Raffles, désirant éviter toute collision avec les sujets de Sa Majesté le Roi des Pays-Bas, allié de l'Angleterre, qu'on disait s'être établis à Riouw, on avait eu soin de ne point imposer par ce traité l'obligation au Gouvernement Britannique de s'immiscer dans l'administration des états voisins de Riouw, Linga etc., ou de

(a) Zie dat stuk sub 22 . 
protéger l'autorité du Sultan au delà de cette partie de l'empire, dans laquelle cette autorité se trouve actuellement reconnue.

Ma surprise a été extrême en lisant ce passage, je cherche en vain la clef de ce raisonnement, aussi faux qu'astucieux; je ne la trouve que dans l'avantage que l'on se promet de fixer un établissement étranger au milieu de nos possessions entre Malacca et Riouw, et dans la recherche infructueuse d'arguments plus plausibles pour s'en emparer.

Indépendamment de la question s'il est permis à un Gouvernement, autre que celui du Roi des Pays-Bas, de s'immiscer dans les affaires du Royaume de Linga, Riouw, Johor et Pahang, dépendant du Gouvernement de Malacca, et fief du Royaume des Pays-Bas, en vertu de traités solemnels, question que j'ai traitée dans ma dépêche du 25 Février, et dont la décision pourrait faire considérer comme superflues toutes celles qui en dépendent, il est cependant intéressant d'examiner les mesures dont le chevalier Raffles s'est cru autorisé à se servir pour parvenir à son but, ainsi que les droits sur lesquels il fonde lui-même ses soi-disants traités.

Je demande d'abord quel est l'empire dont parle le chevalier Raffles? et qui est le successeur dont il fait mention?

L'empire de Linga, Riouw, Pahang, Johor, est une réunion de diverses provinces, toutes soumises à un seul prince, sous le titre de sultan; Singapore et plusieurs autres isles en font partie. Personne avant le chevalier Raffles n'a porté en doute cette réunion; personne, avant lui, n'aurait songé à y voir deux souverains, comme il paraît qu'il en établit le système, quoique cette partie de son raisonnement ne soit pas fort claire, même dans son sens; mais ces difficultés ne l'arrêtent point. Sans s'expliquer sur le reste de l'empire, il déclare que la partie qu'il a désignée de sa propre autorité en est séparée, et veut qu'elle se trouve comme par un coup de baguette détachée des dépendances du gouvernement de Malacca et des pays soumis au sceptre de Sa Majesté le roi des Pays-Bas, et mise sous la protection du gouvernement Britannique.

Il ne s'explique pas non plus sur les causes, qui ont détruit à ses yeux les titres du Sultan règnant de Linga, Riouw, Johor, Pahang etc., soit sur tout l'empire ou bien sur la partie mise sous la protection du pavillon Britannique. Il parait trouver un motif suffisant dans sa seule volonté pour détrôner ou priver d'une partie de ses états, un prince qui 
règne depuis 9 ans paisiblement; qui a hérité le trône conformément à la volonté de feu son père le sultan Mahumed Sjah; dont la nomination a été confirmé par les grands dignitaires et par la nation; dont le gouvernement Britannique a constamment respecté les actes et les sceaux, et reconnu l'autorité en différentes occasions.

Tous ces titres lui paraissent peu valables; il déclare le prince Toekoelon, frère du Sultan, héritier légitime de leur père, le nomme sultan de Singapore, et conclut un traité avec lui. Ce prince Toekoelon se trouvait à Riouw depuis quelque temps, appanagé aux frais du Sultan règnant, confié aux soins du Vice-Roi de Riouw; et il y vivait tranquillement, et il ne m'est pas connu qu'il ait porté aucune plainte contre sa position.

Je ne saurais citer une plus forte preuve à l'appui de l'illégitimité de ses titres, si ceci était encore nécesaire, que la lettre écrite par lui-même au Vice-Roi de Riouw, après l'investiture reçue du chevalier Raffles; votre Excellence en trouve une copie ci-jointe; Elle pourra y voir en même temps les moyens dont le chevalier Raffles a usé de nouveau envers ce prince, qui, quoique interessé à jouir des titres et du pouvoir dont on veut l'honorer, a honte lui-même du rôle qu'on lui fait jouer, et implore l'indulgence et le pardon de celui qu'il considère et considérera toujours, à ce qu'il dit, comme son protecteur et son père. Cette lettre fournirait matière à d'amples observations; je crois pouvoir m'en abstenir, et me borner aux faits qui n'ont guère besoin de commentaires. (a)

Non content d'avoir créé le royaume de Singapore, le chevalier Raffles veut encore établir des relations dans une autre partie de l'empire de Linga, Riouw, Pahang, Johor etc., et pour parvenir à ce but, il n'a aucun scrupule d'engager le Tummengoeng de Johor (soumis au Sultan, comme le vice-roi de Riouw et signataire en cette qualité du traité du 26 Novembre 1818 , dont copie a été envoyée à votre Excellence) à violer ses engagements envers le gouvernement Néerlandais, ainsi qu'envers son maître le Sultan, et à lui faire signer un nouveau traité en contravention à la volonté de ce maître. J'ai été surpris en apprenant cette circonstance. Elle s'explique, depuis que je me trouve en possession d'une lettre écrite au Vice-Roi de Riouw par ce même Tummengoeng, et dont une copie accompagne cette dèpêche. (b)

(a) Den brief te vinden bij Netscher bl. 270 onder No. 4. Verg. sub 20 en 21.

(b) Zie den brief bij Netscher onder No 2 bl. 269. 
Comme le prince Toekoelon (Hussin Mohammed Sjah) il se dit avoir été forcé aux engagements qu'il vient de contracter avec le chevalier Raffles, par les violences que celui-ci s'est permises envers lui. Il écrit ceci de son propre mouvement; il faut donc bien y ajouter foi, et y trouver un motif d'excuse de la perfidie, dont il paraissait s'être rendu coupable avant la connaissance, que j'avais de ces circonstances.

Voilà, Mylord, les plaintes que j'ai à porter de nouveau contre le chevalier Raffles; voilà la conduite, qu'il a tenue en s'appuyant des pleins pouvoirs de votre Excellence, dont il abuse si manifestement! Ces pouvoirs sont datés du 5 Décembre 1818 , époque à laquelle les transactions de nos Commissaires pour la reprise de Malacca, Riouw et autres dépendances ne pouvaient point être connus à votre Excellence.

Il s'inquiète peu de cette circonstance; il poursuit ses plans avec la même ardeur; il se joue des droits de mon Souverain, qu'il n'ignore point; il ne donne seulement pas communication de ses plans hostiles au Gouvernement de Malacca $(a)$, il préfère employer le secret, la ruse et l'intrigue pour n'être pas dévancé dans ses nobles entreprises.

$\mathrm{Si}$ c'est là agir d'après l'intention de nos Souverains; si c'est là user des égards, des convenances qui se doivent des nations amies et alliées, quels moyens se réservera-t-on donc pour un état de guerre et d'hostilité? Aussi j'en appelle à la décision de nos Souverains, j'en appelle à tous les Gouvernements, à toutes les nations, vit-on jamais une conduite pareille en plein paix? Les nations policées se la permettraient-elles même en temps de guerre $(b)$ ?

$\mathrm{Je}$ me repose cependant entièrement sur la justice et sur la loyauté de votre Excellence, et je répète ce que j'ai déjà eu l'honneur de lui dire: Je suis persuadé qu'il suffira de l'avoir mise au fait des circonstances qui ont eu lieu et du point de vue qu'elles présentent, pour que votre Excellence y remédie immédiatement par des ordres prompts et précis adressés à ceux qui ont outrepassé leur pouvoir d'une manière aussi offensante pour le gouvernement Néerlandais. En attendant avec confiance ces mesures de la part de votre Excellence, je ne puis que protester encore de la manière la plus formelle, comme je proteste par la présente en Conseil, contre les actes violents et illégaux que des fonctionnaires

(a) Dat zou dan toch wel naif geweest zijn!

(b) Hoe kwam onze Landvoogd er toe, deze vraag te doen! 
Britanniques ont commis dans des endroits dépendant du gouvernement de Malacca, et soumis au gouvernement de Sa Majesté le Roi des Pays-Bas.

Quoique douleureusement affecté par les circonstances dont j'ai fait mention à votre Excellence, et pénétré des conséquences fâcheuses qui en résultent sous plusieurs rapports, et malgré les provocations répétées et renforcées du chevalier Raffles, je ne me départirai point de la marche calme et mésurée que notre Gouvernement a suivie jusqu'ici en pareilles circonstances, et que votre Excellence a bien voulu reconnaître dans les mesures prises et ordonnées par les Commissaires-Généraux, rélativement à l'isle de Sumatra. Je mets plus d'honneur à contribuer, autant qu'il dépend de moi, à conserver la paix et la bonne intelligence entre nos Gouvernements, pourvu que l'honneur national ne soit point compromis, qu'à faire user de réprésailles locales envers ceux qui, animés par un esprit de jalousie et d'envie, guettent avec avidité chaque occasion qui se présente pour s'introduire furtivement dans tels points de nos possessions et de nos dépendances, où, nous reposant sur la bonne amitié et la loyauté de nos voisins, nous n'avions pas encore pris la précaution d'arborer un pavillon ou placer un détachement de quelques soldats.

Je n'ai aucun doute que votre Excellence ne soit de la même opinion, qu'en voyant les choses en grand, et considérant les vrais intérêts de nos Gouvernements respectifs, Elle ne veuille cordialement concourir à maintenir dans cet archipel un état de choses stable, fondé sur les liens d'amitié qui unissent nos souverains, sur la dignité des deux nations, et sur les égards que les Gouvernements se doivent mutuellement.

En portant à la connaissance du Roi ma correspondance avec votre Excellence, je me trouve heureux de pouvoir écrire en même temps à Sa Majesté que les mesures à ordonner par votre Excellence ne me paraissent point douteuses du moment où Elle aura acquis une entière connaissance de l'état des choses. $(a)$

Bl. 425 noot 54. Het schrijven van Calcutta dd. 3] Juli 1819 aan Raffles luidde als volgt (B) :

Your dispatch dated the $22^{\text {nd }}$ June with its enclosures has been received $(b)$ and submitted to His Excellency the GovernorGeneral in Council.

(a) Zie dien brief aan onzen Koning in Opvattingen sub 157.

(b) Zie bl. 473 . 
His Lordship in Council has derived much satisfaction from the favourable report which you have furnished of the rapid progress of the establishment at Singapore in population and commercial consequence.

His Excellency in Council, in conveying the expression of his approbation of the cautious manner in which you received the overtures described in your letter from several states of the Eastern archipelago, is compelled to notice with different sentiments the measure of deputing Mr. Garling to Pahang.

Such a mission is likely to involve us in further discussions with the Netherlandish authorities. The adoption therefore of this measure, for which there does not appear to have existed any necessity or urgent expediency, is deeply regretted, and, with reference to the repeated injunctions conveyed to you on this point, is entirely disapproved.

Bl. 425 noot 55. De brief dd. 21 Augustus 1819 van het bestuur te Calcutta, welke door mij in onze archieven werd aangetroffen, luidt aldus :

We have the honour to acknowledge the receipt of your Excellency's letter of the $25^{\text {th }}$ March.

2. We addressed your Excellency on the $26^{\text {th }}$ June in reply to your dispatch of the $25^{\text {th }}$ February relating to the occupation of Singapoor, and at that time expressed our sentiments fully on that subject.

3. If we could agree with your Excellency in the assumption that the states of Lingin, Rio, Johor and Pahang constitute a kingdom dependant on the government of Malacca and a fief of the kingdom of the Netherlands, we should long ago have anticipated your wishes by withdrawing our factory from Singapoor; but this is a proposition on which, as yet, we entertain an opposite conviction on grounds pointed out in our letter of the $26^{\text {th }}$ June.

4. We have instituted a strict enquiry with a view to ascertain the exact situation, previously to the treaty of Singapoor, of the prince, whom sir T. S. Raffles represents as being the legitimate sovereign of Johor. If he was, as appears to have been reported to your Excellency, lately residing at Rio, in acknowledged subjection to the Sultan, reigning at Lingin, and under charge of the local Government, we have been grossly deceived on that point. We should be indignant at the authors of so strange a misrepresentation, if it appeared 
wilful. At the same time we have to observe, that it is a circumstance wholly collateral, and in no degree affecting the real terms of the question at issue between your Excellency's government and ours.

5. With respect to the letters written by sultan Hussein Mohammed Sjah and the Tummengong at Singapore to the Raja Mooda of Rio, they can only be explained by the supposition, that in writing such letters, those chiefs wished to deprecate the apprehended wrath of your Government in the event of our not maintaining our establishment at Singapoor. Our accounts do not admit of the belief that any compulsion or menace was used in the treaties which they entered into, or that those treaties were concluded otherwise than with the most perfect good will on their part. We transmitted copies of their declarations on this head in our letter of the $26^{\text {th }}$ June. $(a)$

6. It is with unfeigned regret, that we find ourselves involved in this sort of correspondence with your Excellency; but we cannot charge ourselves with the fault of having caused it. The design of the Netherlandish government in India, clearly evinced and actively prosecuted, to establisch its supremacy in the Eastern archipelago, has forced us reluctantly to adopt measures of defensive precaution, and has led to the discussions in which we are now engaged. Had the supreme Government of Java been contented with the possessions and dependencies indicated by the convention of August I8I4, we should have escaped these differences of opinion, which we have always deprecated and do most sincerely lament.

7. We again beg leave to assure your Excellency, that our sole object is to protect our own interests against what has appeared to us an alarming indication of pretensions to supremacy and monopoly on the part of your Government in seas hitherto free to all parties. We do not covet either the possession of Singapoor or any other possession whatever beyond our old established and permanent factories, and have only resorted to the occupation of such a port as a precautionary measure for the security of our shipping against violences to be apprehended as the unavoidable result of the system, which we construe the Netherlandish government to have adopted. Were the pretensions, to which we allude, admitted, our free trade must be professedly at the mercy

(a) Verg. sub 21 . 
of that latitude, which any commander of a Netherlandish ship of war might please to put upon that assumed supremacy.

8. Together with your letter of $25^{\text {th }}$ March, we have also received one from your Excellency of the $6^{\text {th }}$ February, relative to affairs on Sumatra. We have not received from Bencoolen any report of the circumstances to which it refers.

Bl. 425 noot 56. De brief van het Geheim Committée van den India Board, onderteekend East India House, London $25^{\text {th }}$ January 1820: C. Marjoribanks, G. A. Robinson, W. T. Elphinstone, luidde aldus (B):

I. We have just received by the "Caledonia" your secret despatch of the $17^{\text {th }}$ July 1819 , acknowledging our despatches of the $30^{\text {th }}$ October 1818 and the $27^{\text {th }}$ January 1819 , relating to the conduct of the Dutch in the eastern seas.

2. We lose no time in expressing the satisfaction with which we have perused the letter which you addressed on the $26^{\text {th }}$ June to Baron Van der Capellen $(a)$. The tone of that letter is precisely such as we are desirous that our Governments and public officers should observe towards the authorities of the king of the Netherlands; and although we are not prepared, immediately upon the perusal of it, to express an unqualified concurrence in all the details of the reasoning which it contains, we have no hesitation in saying that we believe it to be generally correct.

3. Upon some facts, especially as to the nature of the relations between Malacca, Riouw and Singapore, we shall look for more particular information.

4. We shall also expect with anxiety the answer of the Dutch regency to that part of your communication, which refers to the alleged claim of that nation to the whole island of Borneo.

5. We have the satisfaction of informing you that your despatch has arrived very opportunely, just as His Majesty's government is about to commence a negotiation with Commissioners to be appointed by His Majesty the king of the Netherlands, with a view to the adjustment of the rights and interests of the two nations in the Indian seas. Your communications upon this subject, and particularly that which we now acknowledge, will be valuable documents in the hands of those who treat on the part of this country.

(a) In B's afschrift staat 25 Juni. Dit is blijkbaar eene vergissing.

6e Volgr. V. 
6. In the meantime we can only enjoin you to preserve, as well in your proceedings as your language, the same moderate but firm tone of which we have had the pleasure of expressing our approbation.

Bl. 425 noot 57. De brief van onzen Gouv.-Gen. dd. 16 December 1819 komt in B's verzameling in het Engelsch vertaald voor. Men vindt hem echter in onze archieven in het Fransch, waarin hij geschreven werd. Het belangrijke stuk luidt aldus:

J'ai eu l'honneur de recevoir à peu de jours de distance les dépêches de votre Excellence en son Conseil, datées le 26 Juin et le 2I Août I8I9, et c'est après avoir délibéré en Conseil sur leur contenu, que je m'empresse d'y répondre.

Qu'il me soit d'abord permis d'exprimer à V. E. mes regrets, en apercevant que tous les raisonnements et tous les motifs, qui se trouvent dans mes lettres du 25 Février et 25 Mars de cette année, n'ont pas suffi pour prouver à V. E. la validité de nos droits sur le royaume de Djohor, que nous considérons comme dépendant du Gouvernement de Malacca, et que l'occupation de Singapore, qui nous parait tellement contraire, non seulement à nos droits, mais aussi aux égards que se doivent nos Gouvernements, soit envisagée de la part de V. E. sous un point de vue entièrement différent du nôtre. Ce qui me fait éprouver un sentiment plus pénible encore, sous un certain rapport, c'est de voir le Gouvernement de S. M. le Roi mon Maître dans cette partie du monde, accusé par V. E. en son Conseil, de signaler ses actions, par une ambition démesurée, par une disposition à étabḷir dans cet Archipel, un monopole de commerce, au profit de notre nation, et tendant évidemment au préjudice et à l'exclusion complète du commerce Britannique.

Ce reproche me parait de bonne foi être aussi peu fondé, qu'il est contraire aux principes qui ont guidé nos démarches, à l'esprit du Gouvernement que j'ai l'honneur de servir et à mes sentiments personnels. Il me serait beaucoup plus sensible, si je croyais le mériter, et s'il était étayé de preuves sans réplique; ce qui heureusement n'est point le cas.

V. E. parle en termes généraux, ce qui me fait présumer que les rapports, qui lui ont été faits à cet égard, ne portent point le cachet de l'impartialité, de la vérité et de l'exactitude.

J'attache beaucoup trop de prix à l'opinion de V. E. en son Conseil, pour ne point m'arrêter un moment sur cette inculpation, et pour ne point tâcher, de désabuser V. E. sur les intentions des Commissaires-Généraux du Roi, et sur 
les motifs, qui ont guidé leur conduite. Indépendemment de nos droits sur le royaume de Djohor, sur lesquels je me permettrai de revenir plus tard, je crois que les mesures que nous avons prises dans cet Archipel, examinées avec une scrupuleuse impartialité, si nécessaire dans des matières de cette nature, prouveront à l'évidence que tout ce que nous avons fait a été dicté, d'un côté par ce que nous devions à l'honneur de notre nation, depuis longtemps si respectée dans ces mers, et dont nous étions chargés de rétablir les droits et le rang qu'elle y avait occupé depuis deux siècles, mais de l'autre côté aussi par ces principes libéraux, par ce désir de cultiver l'harmonie et le bon voisinage, qui existent si heureusement entre nos Gouvernements, par la tendance à faire disparaître partout, autant que possible, les traces du monopole et du commerce exclusif, qui aurait pû se reproduire, si nous n'y avions toujours veillé avec le plus grand soin.

Un examen des instructions, dont nous avons muni nos agents dans nos différents établissements, lors de la première prise de possession, - les ordres qui leur ont été transmis successivement, - notre correspondance avec les princes natifs, peuvent offrir à chaque page des preuves de ce que je viens d'avancer.

Qu'avons nous fait, si non de rétablir en partie des relations, que la Hollande avait formées de bien ancienne date avec la plupart des princes de cet Archipel? et quel sont les changements que nous y avons apportés? Certes point d'avoir restreint, au préjudice d'autres nations et particulièrement des Anglais nos alliés, les stipulations de nos anciens traités; bien moins encore d'avoir contracté leur exclusion d'aucun des établissements que nous avons formés. Tout au contraire notre premier soin a été d'introduire partout les modifications que les circonstances et les temps, dans lesquels nous vivons, exigent, et qui sont si impérieusement voulues par le système, que nous avons adopté en général, et qui établit, partout, la plus grande liberté de commerce.

Qu'on examine les traités, qui nous avons conclus ou renouvellés avec le sultan de Djohor et avec les princes de l'isle de Borneo, notamment de Bandjermasin, de Pontianak, de Sambas, et que l'on me dise de bonne foi, dans quel article se trouve une seule phrase, tendant à ce dont on nous accuse, j'ose le dire, si injustement. Partout liberté de commerce, sans autre exception que le monopole du sel, 
que nous nous sommes reservé dans quelques uns de nos établissements; partout égalité de droits pour nos propres vaisseaux, comme pour ceux des autres nations; partout les mêmes avantages sans aucune différence. Je ne vois là aucun indice de vouloir établir un monopole, de vouloir exclure les commerçants Anglais, qui, s'ils sont justes, doivent reconnaître, dans toute l'étendue de mon Gouvernement, des intentions bienveillantes, toutes les facilités auxquelles ils peuvent s'attendre, et que je leur accorde de si bon coeur. Ce qui a eu lieu à Malacca peut encore en offrir une preuve. Nous trouvâmes, en prenant possession de cet établissement, une différence établie par le Gouv ${ }^{t}$ Britannique entre les droits de douane imposés aux propres batiments et ceux aux quels les étrangers étaient soumis, au préjudice de ces derniers. Immédiatement cette différence a été supprimée, et jusqu'à l'heure qu'il est, nos vaisseaux ne jouissent à Malacca d'aucun avantage ou privilège, dont les vaisseaux Anglais se trouvent privés.

Si j'informe V. E. d'une disposition prise récemment à l'égard d'un traíté conclu par le Gouvt de Malacca avec les princes de Salangore et Rambou, Elle pourra voir combien peu le Gouv ${ }^{t}$ est enclin à favoriser tout ce qui tend au monopole et à l'exclusion du commerce Anglais. A l'instar de ce qui avait été stipulé anciennement avec ces princes, le Gouverneur de Malacca était convenu avec eux qu'ils fourniraient exclusivement au Gouv ${ }^{t}$ Néerlandais tout l'étain que produisent ces provinces, à raison d'un prix fixe. Je n'ai pas plutôt eu connaissance de cette transaction, fondée entièrement sur nos anciens traités, que sans hésiter j'ai désapprouvé complètement la convention; j'ai refusé ma ratification et j'ai donné ordre au Gouverneur d'informer les princes de Salangore et Rambou de cette décision.

Je pourrais ajouter d'autres arguments, tirés du contenu des traités et des instructions données aux agents de notre Gouvernement pour prouver à V. E. combien peu nous méritons le reproche qu'on nous fait, si je ne croyais ceci suffisant pour démontrer le contraire.

Il se pourrait cependant (comme j'ai cru le remarquer dans les lettres de V. E.) que l'on ait cherché un motif de cette accusation dans le choix des différents points de cette Archipel, où nous nous sommes établis, et que cette extension apparente nous attire le jugement si injuste qu'on porte sur nos mesures. 
V. E. établit la proposition que nos droits dans ces parages ne sont fondés que sur le traité d'Août 18I4; je ne fais aucune difficulté d'admettre ce principe $(a)$.

Lors de la conclusion de ce traité, la Hollande se trouva, par suite des événements, qui ont occasioné sa ruine, sans colonies. Ses possessions étaient tombées entre les mains du Gouvt. Britannique. Leur restitution ne pouvait par conséquent s'effectuer que du commun accord des deux Gouvernements. Cet accord se trouve exprimé dans le dit traité, dont. le sens et la lettre porte, que nous serons remis en possession de tout ce que nous possédions au $\mathrm{I}^{\mathrm{r}}$ Janvier $\mathrm{I}^{80} \mathrm{O}$, à quelques exceptions près, qui sont étrangères à la question, qui nous occupe maintenant.

C'est par suite et en vertu de ce traité, que le Roi nomma des Commissaires-Généraux pour reprendre possession de tout ce qui nous avait appartenu, et devait nous être restitué par

(a) $\mathrm{Ik}$ heb deze uitspraak reeds aangehaald sub 77 van mijne verhandeling over Bandjermasin. Zij trok eerst mijne aandacht doordien ik haar, evenals de bezorger van Elout's bijdragen, wel wat al te volstrekt vond; doch verder Van der Capellen's betoog lezende, merkte ik destijds op, dat hij eigenlijk wil zeggen: „Het tractaat van 1814 is de grondslag onzer rechten, in zoover wij ze door de Engelsche verovering met het verdwijnen onzer onafhankelijkheid hadden verloren, terwijl wij in 1814 terugkregen, hetgeen krachtens de geschiedenis ons toekwam." Bovendien vond ik het inroepen dier geschiedenis door Elout van Soeterwoude voor Borneo toch wel wat al te ver gaande, waar wij het land reeds zoo lang hadden verlaten, en zelfs voor Bandjermasin uitdrukkelijk de souvereiniteit hadden opgegeven: het was naar aanleiding dáárvan dat ik mijne aanteekening stelde. Doch dit belet niet, dat ik mij onder dit voorbehoud wel kan vereenigen met de volgende aanmerking, die de oud-commissaris-generaal Elout in zijne sub 58 te vermelden Consideratiën op de zinsnede maakte (Bijdragen E., bl. 49):

„Met allen waren prijs, dien ik op mijn vriends gevoelen stel, komt mij dit niet juist voor.

„Alle plaatsen in Nederlandsch-Indië, die ten tijde van het tractaat van 1814 in Engelsche handen waren, zijn ons teruggegeven.

„Maar nu volgt daaruit niet, dat op die plaatsen, die ons te voren behoorden en niet in Engelsche handen waren, wij geen recht zouden hebben. De vraag is dan maar: hadden wij er recht op in Januari 1803? Ons recht op NederlandschIndië is van ouden datum, steunt op aloude conquesten, tractaten, etc. Dat recht was opgeschort door den oorlog, zooverre het jure belli door de Engelschen was geconquesteerd.

„Door het tractaat revifiëert dat recht; en 't geen door hen niet is uitgeoefend sliep, zoo lang wij niet bij machte waren het te doen werken. In dat recht treden wij nu, na het ophouden der vijandelijkheden, proprio nomine terug. De toepassing van die redeneering is op zich zelve klaar, behoeft geene toelichting.

„Dit alleen er bijgevoegd, dat de betrekking in overoude tijden tusschen Malakka, Singapore, Djohor uit Valentijn duidelijk is." 
le Gouvt. Britannique; et en même temps dans le but de renouer avec les princes natifs les relations, que nous avions eues antérieurement avec eux, pour autant qu'elles paraîtraient offrir encore quelqu'ulitité. Nous avons tâché de remplir cet ordre du Roi. Nous avons repris possession de tout ce qui devait nous être restitué, et après avoir examiné quels étaient les princes natifs, avec lesquels nous avions été liés, nous avons rétabli avec quelques uns d'eux des rapports, qui avaient subsisté depuis très longtemps, sans cependant vouloir rétablir scrupuleusement tout ce qui avait existé. En comparant nos établissements dans l'ère brillante de notre Compagnie des I. O., avec ceux que nous avons rétablis, et le nombre de traités de la même époque avec ceux que nous avons renouvellés depuis le rétablissement de notre Gouvernt. dans les I. O., on se persuadera aisément, que, loin d'avoir donné une extension quelconque à nos étabissements et à notre pouvoir, nous n'avons point rétabli tout ce que la Compie des I. O. possédait autrefois, et que sur plusieurs points, où elle exerçait son influence, nous nous en sommes jusqu'ici entièrement abstenus.

Les établissements, que nous avons formés, et que nous n'avons point trouvés soumis aux autorités Britanniques, sont ceux de Riouw, Linga etc., sur lesquels nous sommes en contestation avec V. E., et ceux formés sur la côte occidentale de Borneo, savoir Pontianak et Sambas.

Peut-être n'aurions-nous pas songé encore à nous établir sur la côte de Borneo, si des invitations réïtérées et très pressantes de la part de chacun des sultans, et surtout la nécessité impérieuse de pourvoir à la sûreté de notre commerce ne nous y avaient engagés. Lorsque par plusieurs lettres de ces princes, conservées dans nos archives, ils nous témoignèrent leur vif désir de se voir replacés sous notre protection, afin de pouvoir par là répousser les fréquentes agressions qu'ils essuyaient de la part de la nombreuse population Chinoise, établie dans leurs états; lorsqu'ils nous prièrent instamment de venir comme ci-devant les guider de nos bons conseils pour l'administration de leurs états, la nécessité de reprimer l'audace toujours croissante des pirates, qui infectent ces mers, nous avait déjà suggéré l'idée de rétablir notre influence sur la côte de Borneo, de tout temps reconnue comme le repaire le plus fréquenté des pirates, et le marché le plus avantageux pour les fruits de leurs courses criminelles, autorisées par la cupidité des chefs ou tolérées par leur fai- 
blesse. La vérité de ce fait pourrait être attesté par le même fonctionnaire, qui paraissant oublier les motifs qui dictèrent sa proclamation du 9 Août 1813 (dont une copie est sous ce pli offerte à V. E. $(a))$, s'avise maintenant de qualifier d'agrandissement illégal le rétablissement de notre autorité dans les ports que lui-même alors considérait comme dépendances des possessions de la très Honorable Compagnie des Indes, sur la côte de Borneo; mais s'il fallait à V. E. d'autres preuves de la nécessité absolue, que le Gouvernement, établi à Java, étende son autorité sur l'isle de Borneo, et même sur tous les petits états indigènes de cet Archipel, je pourrais lui rappeler les annales du commerce de sa propre nation dans ces parages, où elle trouverait des exemples

(a) Zie hier de

\section{PROCLAMATION.}

The port of Sambas and its dependencies on the West Coast of Borneo having been declared in a state of piracy and hostility, and it not being deemed expedient to withdraw the said declaration until due provision for the regulation of the country; Notice is hereby given, that the said declaration is continued in force until further orders and intimation to the contrary may be published in the Java-Government Gazette.

The states of Cootai and Passier with their dependencies on the South East coast of Borneo, having been concerned in various acts of piracy and being in connection with some of the principal pirates, who infect the Eastern seas, are in like manner declared in a state of piracy and hostility, until measures may be adopted to regulate their future conduct; after which, as dependencies of the Honorable company's establishment on Borneo, where no custom-houses are established, they will not be legally open to trade with any vessels but those of the Island.

That no person may plead ignorance hereof, this Proclamation is directed to be published in the English and Dutch languages in the Government Gazette, translated into the native languages, and affixed at the usual places; copies being transmitted to the different residents at the outstations and circulated among the native states.

Given at the Council chamber at Batavia, this 9 day of Augustus 1813.

By me, the Lieutenant-Governor of Java and its dependencies

Tho. S. Raffles.

By order of the Honorable

the Lieutenant-Governor in

Council

C. Assey.

Sec $^{t}$. to Gov ${ }^{t}$, 
fréquents des cruautés les plus insignes et des plus lâches trahisons, pratiqués sur des marchands Anglais, qui visitaient ces ports sur la foi trop souvent violée, des chefs du pays. Les marchands de Java, sans cesse exposés aux mêmes dangers, en ont souvent été les victimes; les paisibles habitants de nos côtes, emportés chaque année en grand nombre par les pirates, se voyaient condamnés à l'esclavage sous les yeux des princes de Borneo, interessés à cet affreux commerce, ou ne pouvant l'empêcher; des bâtiments de cette côte, venaient sans cesse visiter nos ports sous le prétexte du commerce, mais avec l'intention d'épier l'occasion de faire les plus riches prises; enfin, notre cabotage se voyait ménacé d'un anéantissement total, si nous ne tâchions de remonter à la source du mal et d'y porter les remèdes les plus efficaces.

Cet état de choses ne pouvait donc durer plus longtemps, et l'espoir de metre jusqu'à un certain point un frein à ces brigandages et de favoriser par là le commerce et la navigation, qui avaient tant à souffrir de ce fléau, nous détermina à prêter l'oreille aux voeux prononcés des sultans et nous conclûmes avec eux et de leur plein gré, les conventions dont j'ai parlé plus haut, malgré les instigations empressées de $M^{r}$. Raffles, dont V. E. aura eu connaissance par les pièces jointes à la dépêche des Commissaires-Généraux du Io Janvier I8I9.

Nous avons cru de bonne foi mériter la reconnaissance des nations commerçantes dans cet Archipel en agissant comme nous avons fait, et nous étions loin de soupçonner, qu'au contraire on apercevrait dans ces mesures une tendance à un agrandissement dangereux, à une ambition démesurée et à une exclusion du commerce Anglais.

Nous avous cru en établissant une administration régulière, en réprimant autant qu'il dépendait de nous, la piraterie à laquelle les princes de l'isle de Borneo n'étaient pas étrangers, en engageant ces princes d'admettre les vaisseaux et les négociants étrangers comme les nôtres et sous les mêmes conditions, protéger le commerce libre, et donner une preuve de l'intérêt que nous y attachions.

Le seul article dont nous nous sommes réservés le monopole est le sel, dont l'introduction, outre que de Java, est prohibé. V. E. ne considérera point cette stipulation, nécessaire pour faire face en partie au frais de ces établissements, comme une mesure nuisible au commerce Anglais.

Ce monopole est réglé de la manière la moins oppressive 
pour les habitants. Les sultans, avec lesquels le Gouvernement en partage le profit, l'exercaient de 'a manière la plus arbitraire avant les derniers arangements, qui loin d'avoir augmenté les revenus de mon Gouv ${ }^{t}$, nous offrent si peu d'avantages pécuniaires que nous sommes obligés à faire passer des fonds à Borneo pour faire face aux dépenses nécessaires.

Je passe ici sous silence l'établissement de Bandjermasin. V. E. porte connaissance de notre correspondance avec $\mathrm{M}^{\mathrm{r}}$. Fendall à cet égard.

V. E. rélève dans sa dépêche du 26 Juin la réponse faite au major Farquhar par notre Commissaire à Pontianak, comme un des exemples, qui prouvent nos intentions d'agrandissement. J'avoue volontiers que la réponse donnée par $\mathrm{M}^{\mathrm{r}}$. Boekholtz à cette occasion n'était point entièrement conforme à l'esprit de ses instructions et que les expressions, dont il s'es servi, n'ont point approuvées le Gouvernement. J'avoue volontiers qu'il aurait du se borner à inviter le major Farquhar à ne point entraver nos négociations avec les princes de Borneo avec lesquels nous étions sur le point de conclure des traicés et de renouer d'anciennes rélations, rompues par suite des évènements, au moment où le départ précipité du Major retardait la remise de Malacca à nos commissaires.

Le second exemple, allégué par V. E. en son Conseil pour faire preuve de nos vues ambitieuses et confraires aux intérêts Britanniques, c'est la conduite tenue par nous relativement au royaume de Djohor.

Je ne puis que me référer ici à ce que j'ai eu l'honneur d'écrire à V. E., dans ma dépêche du 25 Février dernier. Je ne répèterai point les arguments, dont j'ai fait usage alors, pour démontrer nos droits, dérivés du Traité de 1784, tacitement rétabli par celui de $18 \mathrm{I} 4$, qui nous a remis dans la possession de nos colonies, et dont le sens ne peut être autre que de rétablir le status ante bellum, lequel ne permet aucun doute relativement à nos droits sur le royaume de Djohor.

Il est nécessaire cependant que je réponde à une objection que je trouve dans la lettre de V. E. du 26 Juin. Je lis au $\S 37$, que les autorités Britanniques ont du considérer comme authentiques et valables les déclarations des fonctionnaires Hollandais, qui n'ont jamais été contredites pendant les 23 années que vous avez occupé Malacca, $n i$ pendant la guerre, $n i$ pendant la paix. Or je demande de bonne foi; 
Quand et à quelle époque prétend-on que nous aurions pu faire valoir nos prétentions? Pendant la guerre? L'occasion s'est-elle jamais présentée, et la Hollande pouvait-elle avoir le moindre intérêt à informer pendant la guerre le gouvernement Britannique de la circonstance dont il s'agit? - Pendant la paix? Mais la paix d'Amiens a interrompu à peine la longue guerre, dans laquelle ia Hollande a été entrainée, et la reprise des hostilités en 1803 a empêché la réoccupation de Malacca et de ses dépendances. Si on avait repris possession de cet établissement par suite du traité d'Amiens, c'est alors que se serait présentée la question; c'est alors qu'on aurait trouvé l'occasion de s'entendre à cet égard, si la chose avait été jugée nécessaire; et c'est alors que les autorités Hollandaises auraient agi sans le moindre doute, d'après les mêmes principes, qui nous ont fait reprendre nos droits, dès que les stipulations du traité de I8I4 ont été mises en exécution. Il me parait donc clair, que depuis 1795 jusqu'à 1818 , il n'a jamais pu être question d'éclairer le gouvernemen Britannique sur l'état de la question, sur laquelle nous différons d'opinion.

V. E. dit que pour la convaincre de nos droits, il faudrait d'abord prouver que le Royaume de Djohor est une dépendance de Malacca, et démontrer ensuite que Singapore dépend de Riouw ou de la principauté dont le gouvernement réside à Riouw.

Après m’être expliqué déjà sur la première question, il me reste à traiter la seconde. Quelle que soit l'opinion, que l'on adopte sur nos droits en général, il ne peut à mon avis exister aucun doute sur ce point.

Je crois de bonne foi, que cette question n'a jamais été agitée, et que le chevalier Raffles est effectivement le premier qui ait mis cette idée en avant. La manière dont cette question est exprimée, dans la lettre de V. E. pourrait donner lieu à quelque incertitude, qu'il est nécessaire d'écarter. Singapore n'est effectivement pas plus une dépendance de Riouw, que Riouw ne dépend de Singapore. Comme je l'ai observé dans ma dépêche du 25 Mars, le Royaume de Djohor est un ensemble, composé de Djohor, Pahang, Riouw, Lingen, Singapore et plusieurs autres parties, qu'on ne nomme point en désignant le Royaume: Singapore fait donc partie du Royaume, et c'est tout ce qui est nécessaire d'établir.

Une autre question, relative à la discussion présente, et dont V. E. fait mention, est celle de savoir si le Sultan 
régnant à Lingen, est le souverain légitime, ou si son frère Toekoelon, avec lequel le chevalier Raffles a conclu un traité, le reconnaissant comme Sultan, doit occuper le trône du royaume de Djohor.

D'abord on croirait qu'un règne paisible pendant 9 années consécutives, reconnu non seulement par toutes les autorités voisines et subordonnées, mais encore par le Gouvernement Britannique à plusieurs occasions, comme je l'ai remarqué dans ma lettre, citée du 25 Mars, devrait mettre ce Prince à l'abri d'un examen ultérieur de ses droits et de ses titres. Jamais avant le chevalier Raffles, on n'a songé à les contester, et celui-ci attend, pour établir ce nouveau système, le moment où il a besoin de s'en prévaloir pour couvrir d'un motif apparent la prise de possession d'une isle, à laquelle il n'avait aucun droit. Cette conduite de sa part est d'autant plus extraordinaire, qu'en I8I3 le même chevalier Raffles, alors $\mathrm{L}^{\mathrm{t}}$. Gouverneur de Java, reconnut officiellement le même sultan, auquel il dispute aujourd'hui le droit au trône. Il serait difficile de trouver un exemple d'une inconséquence pareille. V. E. verra dans la lettre du chevallier Raffles, dont je joins une copie, et dont je garantis l'authenticité, la preuve de ce que j'allègue $(a)$. Il faut dont que le chevallier Raffles ait fait après cette époque la découverte des droits du frère du Sultan, qu'il défend aujourd'hui avec tant de chaleur.

Je ne vois pas trop pourquoi Mr. Raffles prétend dans sa lettre du I3 Fevrier I8I9, que le Vice-Roi de Riouw n'exerce dans cet établissement qu'une autorité très borné, et n'est point chargé de l'administration générale $(b)$. Le contraire est

(a) Van der Capellen bedoelde het volgend opschrift van den brief:

Cette lettre amicale, accompagnée de l'assurance d'une affection bien sincère, vient de moi Sri Padoeka Honorable Thomas Stamford Raffles Esquire, Lieutenant Gouverneur-Géneral, le sublime, qui gouverne en chef, qui du trône de Java règne sur tous les pays de l'Orient.

Fasse Dieu qu'elle parvienne à mon noble et fidèle ami Paduka Sri Sultan Abdul Rahman, assis sur le trône du Royaume de Djohor, Pahang et toutes dépendances, etc.

Van der Capellen schreef hieronder:

Ceci suffit pour prouver que Monsieur le Lieutenant-Gouverneur Raffles en I8I3 reconnut le sultan Abdul Rahman pour souverain de Djohor, Pahang etc. etc.

(b) Zoowel in den Franschen brief op het Ministerie van Koloniën, als in de Engelsche vertaling te vinden in B's verzameling, staat abusievelijk, dat de hiẹ 
prouvé à tous ceux, qui connaissent l'état actuel des choses et ceci est tellement avéré que c'est au Vice-Roi de Riouw, que le major Farquhar s'est adressé pour obtenir d'abord la

bedoelde brief van Raffles gedagteekend is 13 Februari 1818. Raffles deelt in dat schrijven aan Calcutta, waarvan de regeering aldaar een extract naar Batavia zond en hetwelk men in onze archieven aantreft, het volgende mede:

8. The kings of Johore trace their descent through a line of twenty five sovereigns, commencing from the first Hindu prince, who established himself at Singapore in the year II60; after various vicissitudes, in consequence of which they removed the seat of their Government first to Malacca and subsequently to Johore, they were ultimately obliged bij an invasion from Menangkabow to abandon Johore, in the early part of the last century.

The Sultan fled to Pahang, where he died; but his Bandahara or first officer of state proceeded to Malacca and other places on the coast, where he engaged several Bugguese chiefs in the service of the King. - With these auxiliaries the Bandahara sailed for Rhio, where after some time the heir of the deceased king was proclaimed Sovereign of Johore.

This Prince in reward of the services eventually rendered him by the Bugguese (natives of Celebes) ordained and determined that the Rajah Moodah or vizier of Rhio should always be a prince of Bugguese extraction, and should be charged with authority over all the Bugguese and other traders resorting to it. - The Sultan himself generally resided at Rio or Lingin, and exercised a general control over the states of the Empire, which those already mentioned, comprehended also the separate Governments or rather kingdoms of Pahang and Johore.

9. Conformable to the long established usage of the Empire, founded perhaps originally on the natural divisions of the states composing it, the great council of Johore was constituted as follows:

First. The eldest son of the reigning monarch, who was also the legitimate successor to the throne.

Second. The Bandahara and Chief of Pahang.

Third. The Tummungung and Chief of Singapore and Johore proper, which comprehended the islands and the southern extremity of the Peninsula, and

Fourthly, the Indrabongso, whose title is now extinct.

The great offices of Bandahara and Tummungung have never ceased to exist, and when the number of the princes of the blood has admitted of it have always been filled bij the sons of the Sulthan. If on the contrary he had no male offspring, the title of Bandahara was conferred bij his pleasure and carried with it the right of succession to the crown, while the other offices were either filled up by 
cession d'une des isles de Carimon, et ensuite pour celle de Singapore, et que c'est à lui que le Sultan, à qui il s'était adressé en premier lieux, comme au chef de l'Empire, l'a

his warrant or descended by inheritance from the previous occupant.

Io. It may be material to observe that the Rajah Moodah of Rio had only a local jurisdiction; being necessarily a Bugguese, he had no voice in the Government and was particularly "excluded from all affairs which had a reference to the political interests of the Malayan empire.

II. The tranquillity of these states had long been disturbed bij the restless ambition of the Dutch Compagny and the intrigues of the -Bugguese, when on the establishment of the British at Malacca in I795 one of His Majestys ships conveyed the legitimate sovereign Sultan Mahummud Shah to Rhio and established him in the independant government of his dominions, from whence he had been in temporary exile. The acknowledgment of his independence by the English, the personal character and talents of the Sultan, and the attachment of the Malayo to their ancient constitution and to their legitimate Sovereign, soon reorganized the Empire and consolidated the power of this Prince, whose reign was in general tranquil and prosperous. He died about six years ago, universally respected, and according to the constitution and custom of the state, he previously declared and installed his eldest son Tuankoo Loong as his successor of the throne of the Empire. This Prince has since assumed the title of Sultan Hussein Mahummud Shah.

I2. The death of the late Sultan unfortunately. took place at a period when his successor was absent from the seat of Government, on a visit to his relation the Bandahara at Pahang; between this place and Lingen communication can only be held in the favorable Mousoon, and nearly a year had elapsed from the fathers death, before his son arrived to take possession of his hereditary rights, and to assume his legitimate authority. During the interregnum however, the chieftains, who possessed the local authority, both at Lingin and at Rhio, had found means to extend their influence and to throw obstacles in the way of the regular succession, which either by subverting the constitution or dismembering the Empire, would tend to perpetuate their independent power; the heir to the throne was poor, and had no means of assembling a force to support his rightful claim, while the Bugguese chief of Rhio was rich and surrounded bij his tribe. Under the pretence of waiting until all the distant chiefs were assembled, the installation of the new Sultan was deferred .... (de copiist schreef $n a$ „deferred" „senidu”); - and a small part of the port duties of Rhio was assigned for his subsistance.

The second son of the late Sultan, who is understood to be of an 
renvoyé, comme à son mandataire général. La pièce ci-jointe $\mathrm{N}^{\circ} 3$ prouve tout ceci $(a)$.

Pour en revenir au Sultan Abdul Rahman Sjah, actuellement règnant, V. E. verra par les lettres ci-jointes, adressées à ce Sultan par le Prince Toekoelon $(b)$, par le Tommengoeng de Djohor $(c)$ et par le Bandahara de Pahang $(d)$, si effectivement

easy disposition and of weak intellect, continued in the meantime in the nominal exercise of authority at Lingen, and it ultimately accorded with the policy of the Bugguese chief of Rhio to consider this person as his immediate superior; the empty allegiance and honors necessary to a chief of his own creation being more easily rendered than the substantial rights of the legitimate Sovereign to the established portion of the revenues of Rhio and to the undivided authority of the states. (In de drie laatste regels zal wellicht een copižstenfout schuilen.)

(a) De brief over een der Karimon-eilanden, gelegen bij Singapore, besloot nl. aldus:

Je m’endresserais à cet égard à mon ami à Linga (aan Sultan Abdul Rahman Sjàh), mais celui-ci a muni mon ami (den Onderkoning, aan wien Farquhar schreef) de plein pouvoir pour traiter de toutes choses: voila pourquoi je n'écris pas à Linga.

(b) Deze brief ving aan:

Louange a Dieu, le seul Eternel, l'Immuable, le Conservateur de tout ce qu'Il a créé!

Que la paix de Dieux et sa clémence reposent sur les Prophètes, sur leurs familles, leurs amis et alliés!

Ayant rendu le tribut de louange dû à l'Eternel, et après avoir imploré le salut et la paix sur les prophètes, Padoeka Tongka Lon envoie cette lettre, avec des salutations provenant d'une affection sincère à Sri Paduka, son frére, son Souverain pour le règne duquel il fait des voeux, afin qu'il soit béni et de longue durée, que Dieu prolonge sa vie, lui accorde la santé, augmente de plus en plus sa grandeur et sa gloire, lui conserve șon coeur droit et son esprit éclairé, pour le bonheur de ses sujets, qu'enfin un jour il l'admette au paradis! Dieux Tout-Puissant exauce ce voeu!

„Le reste de cette lettre" - luidde de ondergeplaatste toelichting - „traite d'affaires indifférentes; iI suffit du titre de Souverain, que donne Toekoelon à son frère, pour faire preuve qu'il le reconnaissait pour tel."

(c) „Dato Tommangong, ton esclave, se jette aux pieds de son auguste Souverain. Pardonne, o mon Maître, à ton esclave, son humble prière. Sois clément et accorde lui la permission d'aller chercher de quoi vivre, de s'embarquer pour où Dieu le conduira.

„Ta bienveillance excusera la demande de ton vile et humble esclave.

"Ecrit au temps permis, le 3 de Sappe 1224."

(d) „Dato Bandahara, ton esclave, se jette aux pieds de son auguste Souverain 
il est reconnu par eux, pour leur souvrain et leur maître, ou bien si c'est une assertion hasardée de notre part. Quelques une de ces pièces sont écrites, avant la remise de Malacca au Gouvernement Neêrlandais. On ne dira au moins pas cette fois-ci, que la crainte pour l'effet de notre vengeance ait dicté ces lettres $(a)$, que je fais parvenir à V. E. dans la langue Malaise, comme elles ont été écrites, pour ne pas courir risque d'altérer les expressions par une traduction.

J'ai l'honneur de joindre encore à ces pièces, une déclaration, donnée par le sultan de Djohor, pour expliquer sa conduite envers les agents Britanniques et ensuite envers les commissaires Neêrlandais, avec lesquels il a conclu le traité du 26 Nov. I8I8 (b).

Quoique ceci pourrait suffire pour démontrer la reconnais-

Pardonne o mon Maitre, à ton esclave, qu'il ose adresser celle-ci, pour te faire savoir, que lundi le $17^{\mathrm{e}}$ de Dzulkaida, à 8 heures, il est descendu du fleuve de Pahang, pour aller se rendre aux pieds de son Souverain. Arrivé à l'embouchure, ton esclave trouva le vent soufflant du Nord; cependant il voulut poursuivre son chemin: mais voyant l'intention de ton esclave, les deux frères Said Husin et Said Mahmud, de même que l'envoyé Said Ahmad avec quelques anciens du peuple, retinrent ton esclave, et dirent que le moment n'était pas favorable pour partir. Ton esclave alors céda à la prière de ces vieillards, mais trembla pour son maître. S'il plait à Dieu, et que nul empêchement ne survienne, ton esclave espère se jetter aux pieds de son Souverain dans le mois de Rabioul Akir prochain. „Ce vendredi, 21 de Dzulkaida 1225."

(a) Dit heeft betrekking op de wederspraak, vervat in de sub 21 vermelde brieven.

(b) De brief luidt aldus:

Nous Sultan Abdul Rahman Sjah, descendant du Sultan Mahmud Sjah, roi de Djohor, Pahang, Riouw, Linga et dépendances.

Conjointement avec

le radja Djaphar, Vice-Roi de Riouw, qui a agi en notre nom, et en qualité de notre plénipotentiaire, dans les affaires donc cet acte fait mention;

Publions par celle-ci et faisons connaître ouvertement et à la face du monde entier, les circonstances qui Nous ont porté à conclure deux traités, l'une avec la Compagnie Anglaise du I6 $^{\text {de }}$ Sjawal au jour de mercredi de l'année I 233 (I9 Août I8I8), l'autre avec la Haute Régence des Indes Neêrlandaises au 27 de Moeharam, jeudi de l'an 1234 (26 November $18 \mathrm{I} 8$ ) trois mois après le susdit traité avec les Anglais.

D'abord il est à observer qu'une alliance non interrompue entre le royaume de Djohor et la Compagnie Hollandaise, date depuis deux siècles et davantage; que depuis la conclusion de ce premier traité, entre le royaume de Djohor et la Compagnie Hollandaise, les souve- 
sance de la légitimité du Sultan règnant, il peut être intéressant d'appuyer cette légitimité, qu'on s'est avisé de disputer par d'autres preuves et par un récit succint de ce qui s'est passé lorsque le Sultan règnant monta sur le trône.

Mr. Raffles prétend dans sa lettre du I3 Févr. I818, dont V. E, m'a fait parvenir un extrait, qu'à la mort du Sultan défunt, pêre du Sultan actuel, le Prince Toekoelon a été

rains de Djohor dans toutes leurs transactions politiques se sont constamment réglés d'après le gouvernement de Malacca.

Il est vrai que dans la suite des temps la guerre est survenu entre les souverains de Djohor et la Compagnie Hollandaise; mais en I 200 ( 1784 ) la paix a été rétablie et un traité conclu, en vertu duquel une garnison de la Compagnie Hollandaise fut laissée à Riouw.

Celle-ci y resta effectivement jusqu'en I2OI ( 1785 ) lorsqu'elle fut obligée de se retirer, à cause du grand nombre de pirates d'Ilanon, qui se rendirent maîtres de Riouw. Cet évènement devait rendre moins fréquentes les relations entre la Compagnie Hollandaisse et le Roi de Djohor; et lorsque ensuite le pavillon Hollandais fut baissé à Malacca, les Anglais auraient sans doute remplacé les Hollandais dans leurs relations avec le Royaume de Djohor, s'ils l'avaient désiré.

Cependant ils n'en firent rien, et dès lors toutes relations avec le Roi de Djohor cessèrent jusqu'en I 233 (I8I8). Ce ne fût qu'à cette époque et bien peu de jours avant la remise de Malacca aux Hollandais, que le major Farquhar, résident à Malacca, vint chez nous pour entrer en négociation. Il nous surprit par l'impétuosité de ces instances, par l'empressement qu'il mit à hâter cette négociation. Nous étions alors hors de toutes connections; nous ignorions si de la part de nos anciens amis, les Hollandais, on aimerait à renouveler les anciennes relations, qui avaient existé en nous; nous avions des nouvelles et des lettres d'autorités Anglaises pour nous instruire du dessein des Hollandais, qui, disait-on, viendraient avec un grand nombre de troupes pour s'emparer de nos états. Dans ces lettres ces seigneurs Anglais nous marquèrent leur grand étonnement sur la manière d'agir des Hollandais, qui, de cette façon s'écartaient de ce qui étaient stipulé dans un traité majeur conclu en Europe entre l'Angleterre et la Hollande. (Men zie den brief op bl. $46 \mathrm{r}$ »Opvattingen"; ov. $12 \mathrm{r}$.)

En lisant ceci, l'idée nous vint que, malgré la restitution de Malacca à la Hollande, ce traité pourrait contenir quelque exception à l'égard de nos états, et nous nous imaginions que nous pourrions être empêchés par là de renouer nos relations avec nos anciens amis.

Cette considération seule nous détermina à accéder au contrat qui nous fut présenté par le major Farquhar, nous fiant de bonne foi à tout ce qu'il nous suggéra, et donnant pleine croyance au contenu de 
nommé par lui son successeur; qu'il a prit le titre de Sultan Hussein Mahummed Sjah; qu'il a été empêché par plusieurs circonstances de prendre possession du trône de feu son père; et qu'en attendant, les intrigues du Vice-Roi de Riouw et de quelques autres ont supplanté au successeur légitime, son frère puiné, le Sultan actuel.

J'aurai bien désiré voir quelques preuves à l'appui de ce récit entièrement contradictoire aux circonstances, qui sont parvenues à ma connaissance, et dont je crois pouvoir produire les preuves.

Voici ce qui m'a été rapporté: Quelque temps avant sa mort, le Sultan défunt a muni Radja Djafar, Vice-Roi de Riouw, d'un plein pouvoir, tant pour traiter toutes les affaires du Royaume, que particulièrement pour lui conférer le droit de nommer le successeur au trône. Radja Djafar a fait usage de ce droit, et a nommé au nom du Sultan et en vertu de ses pleins pouvoirs, Abdul Rahman Sjah, successeur au trône du Royaume de Djohor. Probablement Abdul Rahman Sjah a été préféré à son frère Toekoelon, à cause de la légitimité

la lettre de cet autre seigneur Anglais. Ce traité d'aillleurs ne nous promettait pas le moindre avantage.

Après tout ceci, vint le Contre-amiral Wolterbeek, qui ayant replacé le pavillon Hollandais à Malacca se rendit auprès de nous. Il nous apprit que tout ce qui avait appartenu à la Hollande était restitué aux PaysBas, qu’à la vérité il existait des exceptions à cet égard, mais qu'il n'était nullement fait mention dans ce traité majeur du Royaume de Djohor.

Nous vîmes ainsi bien clairement et positivement que nous avions été induits en erreur, lorsqu'on nous pressa si fortement de conclure à la hâte un contract; que particulièrement nous avions été trompés par ceux qui nous annoncèrent l'invasion prochaine des Hollandais dans notre pays.

Car ceux-ci, nos anciens amis et alliés, avaient l'intention de renouveler les connections antérieures d'une manière plus avantageuse que jamais.

Nous éprouvâmes une grande joie en voyant que le désir de notre coeur s'accordait avec ce qui nous prescrivait notre devoir. Nous annulâmes le contract, fait avec précipitation et à une époque très inconvenable, et ce fût avec un vraie satisfaction que nous conclûmes avec nos anciens amis un traité, qui bien pésé de part et d'autre, devait tendre au bien-être de nos états et au bonheur de nos sujets.

Pour donner l'authenticité requise à cet écrit, contenant un exposé fidèle de notre conduite et des motifs qui y ont donné lieu, nous y apposions nos sceaux et signatures.

Fait à Linga, ce 30 du mois de Radjap; lundi r234 (1819) 25 Mei. 6e Volgr. V. 
de sa naissance $(a)$, prouvée entre autres par le document ci-joint, coté $\mathrm{N}^{\circ} 8$, où l'on voit, que sa mère, la princesse Intje Mariam a été légitimement mariée au Sultan (b). Toe-

(a) Vermoedelijk wordt hier eene technische fout gemaakt, waaraan schrijvers over Indische aangelegenheden zich dikwerf schuldig maken. Het huwelijk van Toekoelon's moeder zal wel niet minder "wettig" geweest zijn dan dat van Abdoerahman's moeder; doch deze was de dochter van een Maleisehe groote, bandara Hasan, terwijl gene van lage Boegische familie was, namelijk „eene gemeene pandelinge, genaamd Mako", waardoor haar zoon "in geen aanmerking omtrent het succesśierecht" kwam, gelijk reeds in Februari 1786 onze resident van Riouw had gerapporteerd! Ten bewijze dat hierop al vroeg werd gelet, strekke dat de naamgeving van Abdoerahman met het opvolgingsrecht verband hield. Als regel gold toch bij de Maleische vorsten, dat zij om den anderen een naam van gelijken oorsprong voerden; en zoo behoorde op sultan Mahmoed de gemaal der beide moeders, eene samenstelling met het woord Abdi te volgen. Netscher bl. 247-249.

Het feit, dat Toekoelon's moeder eene Boegische was, makt Raffles' uiteenzetting in zijn rapport dd. 13 Februari 1819 op bl. 511 noot (b) afgedrukt, te onwaarschijnlijker, dat de Onderkoning slechts gezag had over de Boegies, daar hij het nochtans was, die Toekoelon's verheffing op den troon, in strijd volgens Raffles met het bestaande recht onmogelijk maakte.

Nog zij hier opgemerkt, dat slechts bij wijze van spreken over een oudere door een jongere, sultan Abdoerahman den Onderkoning kon noemen zijn vader, gelijk hij deed in den brief dd. 11 Augustus 1818 aan Farquhar, afgedrukt in noot (a) bl. 444 .

(b) Deze bijlage luidt aldus:

Ce jeudi 9 de Sjaban de l'an I 234, à trois heures après midi, Nous Radja Djaphar, Vice-Roi, fils du Vice-Roi Radja Hadji, mort dans la guerre contre les infidèles, avons apposé Notre sceau et Notre signature au présent acte, fait à Linga, pour déclarer qu'à cette époque nous nous trouvions chez Padoeka Sri Sultan Abdul Rahman Sjah, lorsqu'un envoyé du Gouverneur-Général, son aide-de-camp, chargé d'une mission auprès du Sultan Sri Paduka Abdul Rahman Sjah, et muni de lettres de créance, arriva de Batavia à bord d'un vaisseau de guerre.

Il était chargé de faire des recherches sur quelques circonstances, qui avaient eu lieu dans le royaume de Djohor, Pahang, Riouw, Linga et dépendances.

Ayant terminé les affaires à Linga, le capitaine Elout s'informa encore de l'époque à laquelle fût conclu le mariage entre la mère de notre Souverain Intjé Mariam, résidant à son palais, et feu Paduka Sri Sultan Mahmud. Nous lui répondîmes que ce mariage avait été conclu dans l'année I I94, en présence de feu notre pére Radja Hadji, et au palais de notre tante la princesse Ongkie Radja Halima, que celui qui administra la cérémonie était un certain prêtre nommé Jacob de Batavia, que les Walis (personnes qui font fonctions de tuteurs de la fiancée), pris entre les plus proches parents, étaient le slewatang Ibrahim et le sabandar Mohammed, que tout le monde à Linga et à Riouw peut 
koelon, quoique reconnu comme prince de l'Empire, aurait de la peine, je crois, à produire un document semblable en sa faveur.

V. E. trouvera dans la pièce ci-jointe et côtée $\mathrm{N}^{\mathrm{r}} 9$ un document, faisant foi du plein pouvoir dont le Vice-Roi de Riouw s'est trouvé muni; cette pièce, comme la précédente, est signée par plusieurs grands du Royaume, qui ont été présents, et qui ne peuvent point être soupçonnés d'avoir signé une fausse déclaration. (a)

Voilà, Mylord, une exposition aussi exacte que vraie de ce qui concerne les droits des princes dont il s'agit, telle qu'elle m'a été faite et à laquelle je n'ai aucun lieu de porter le moindre doute. Je prie V. E. de la comparer aux rapports qui lui ont été faites, et il ne lui sera pas difficile alors de juger de quel côté se trouve le bon droit, la loyauté; et où les intrigues, l'astuce et la mauvaise foi.

avérer ceci parceque ce mariage est connu de tous ceux qui connaissaient les hauts personnages mentionnés.

Notre sceau est apposé sous cet acte, pour lui donner toute authenticité.

(a) De bedoelde volmacht:

Ce jeudi 14 du mois Dzulkaida de l'an I 226 à midi le Vice-Roi Radja Djaphar, fils de feu Radja Hadji, mort dans la guerre contre les infidèles, a été nommé plénipotentiaire général du Sri Paduka Sultan Mahmud Badaroedin Rayah Sjah, bien entendu, avant son décès, et avant d'avoir fait ses dernières dispositions.

Ensuite le Prince Vice-Roi a été de nouveau chargé de l'exécution de toutes les affaires, et principalement pour la nomination d'un souveverain et tout ce qui s'y rapporte. Ceci eût lieu peu de temps avant la mort du dernier Sultan, mais pendant qu'il jouissait encore de l'usage de toutes ses facultés, qu'il était en état de suivre sa propre volonté, et qu'il vivait en pleine tranquilité.

Temoins de cet acte furent de la part des princes du sang, Tunko Osman, fils du Sultan Sleman, Ongko Boero, Tunko Zinal, Ongko Said Sjarif Mahadnedzin, fils de feu Habib Abdul Rahman Kadesie, le datoe selewatang Ibrahim, fils du datoe Bendarah Hasan, le datoe bandar Moehamad, fils du datoe bendarah Hasan, intje Abdul Manan, intje Kalo, le panglima du dalem, et le panglima des affaires de la guerre Djoemal, et de plus un grand nombre d'autres princes du sang et grands du Royaume, tous présents.

Celles des personnes ci-nommées, encore en vie, pouvant se presenter comme témoins, ont apposé leurs signatures à cet effet.

Fait à Linga, le ro de Sjaban, à 9 heures, I 234 . 
Il m'est bien pénible en vérité de devoir m'exprimer de cette manière, comme en général il m'est extrêmement douloureux de me trouver enveloppé dans des discussions de cette nature avec V. E., avec laquelle je ne voudrais avoir à traiter que des sujets agréables, et conformes à la bonne intelligence qui règne entre nos gouvernements; mais je proteste qu'il n'y a point de ma faute, et que je considère le chevalier Raffles, comme le seul auteur de toutes les contestations, qui se sont élevées entre nous, et que je serais heureux de voir terminées le plutôt possible.

Après tout ce que je viens d'avoir l'honneur de commumuniquer à V. E., Elle ne pourra point être surprise de me voir déclarer par la présente, au nom du Gouvernement, dont je suis le chef, que je persiste dans tout ce que j'ai écrit dans mes dépêches précédentes, me trouvant obligé de protester encore de la manière la plus forte, contre l'occupation de Singapore par les autorités Britanniques, et contre le pouvoir donné d'une manière arbitraire et injuste au prince Toekoelon, frère du Sultan règnant, sur le royaume de Djohor, après que les droits de celui-ci, renforcés d'ailleurs par une possession paisible de neuf ans, avaient été reconnus par le même Gouvernement et par le même fonctionnaire, qui aujourd'hui les lui dispute

Je vois par le contenu des dépêches de V. E. du 26 Juin et $2 \mathrm{I}$ Août, qu'elle est d'avis qu'il sera nécessaire d'attendre les ordres de nos Souverains, avant de prendre une décision sur les questions qui se sont élevées.

J'y vois aussi que de l'aveu de V. E. en son Conseil, le chevalier Raffles a transgressé ses instructions, en prenant possession de Singapore; que V. E. aurait désiré qu'on n'en eut pas pris possession après avoir eu connaissance des prétensions, justes ou injustes, formées de notre part.

Je reconnais dans tout ce que V. E. dit à cet égard, cet esprit de justice et d'équité qui la distinguent, et qui est si agréable de rencontrer, même dans les cas où l'on diffère d'opinion. Je remercie V. E. de m'avoir communiqué cette manière de voir. Mais en même temps j'ai lieu d'espérer que ces mêmes sentiments porteront encore V. E. à accéder à la demande que je lui ai faite précédemment, savoir de donner les ordres nécessaires pour l'évacuation de Singapore. Si V. E. n'aurait pas ordonné d'en prendre possession, en cas qu'Elle eût en connaissance de nos prétentions, Elle ne voudra certainement point que cet état de choses, dont elle désapprouve l'origine, se prolonge davantage. 
V. E. est beaucoup trop juste pour se laisser arrêter par les difficultés dont Elle fait mention. Ce n'est pas l'honneur Britannique, qui est compromis ou qui le serait, si V. E. donnait l'ordre d'évacuer l'isle de Singapore, mais c'est bien mon Gouvernement, qui l'est de la manière la plus forte, tant que nous voyons des fonctionnaires et des troupes étrangères au milieu de nos établissements, et à leur grand détriment; tant que nous voyons un Prince, qui à nos yeux n'a aucun droit aux titres et aux dignités qu'on lui assigne, gouverner, sous la protection de fonctionnaires et d'une force armée Britannique, une partie des états du Sultan légitime et reconnu, à la face de ce même Sultan, auquel nous avons promis protection au nom du Roi notre Souverain.

Je prends la liberté de me référer encore à cet égard à ce que j'ai eu l'honneur d'écrire à V. E. dans ma lettre du I3 Avril $(a)$, et je réitère de nouveau et avec instance la demande que je lui ai faite alors.

Hierop volgde nog een P.S., waarin verwezen is naar twee bijlagen, gemerkt 10 en 11 , houdende brieven van Toekoelon en van den toemengoeng van Djohor, waaruit mede bleek dat deze den regeerenden sultan van Djohor Abdul Rahman Sjah als hun souverein erkenden. Beide brieven zijn afgedrukt bij Netscher bl. $270 \mathrm{~N}^{\circ}$. 4 en bl. $269 \mathrm{~N}^{\circ} \mathrm{l}$. Dat van Engelsche zijde werd opgemerkt de brieven niets bewezen, teekende ik bereids bl. 407 aan.

Bl. 425 noot 58. De woorden van Elout komen voor in diens nota van November 1819, houdende zijne Consideratiön nopens de afiloening der verschillen tusschen Groot-Britanië en de Nederlanden, waaruit de instructie is voortgevloeid, die onze gemachtigden Fagel en Elout naar Londen medekregen, voor de onderhandelingen ter herziening van het tractaat van 1814. Zie Bijdragen E. bl. 49.

" 425 noot 59. Zie Bijdragen E. bl. 128.

" 425 noot 60 . Het schrijven van onzen Gouv.-Gen. dd. 9 November 1819 aan het Opperbestuur luidde aldus:

Ten vervolge mijner missive van den 24 September jl. $\mathrm{N}^{\circ} 7$ Sekreet $(b)$, heb ik de eer Uwer Excellentie te doen toekomen

(a) Zie dien brief sub 61 van mijn Bandjermasin-opstel.

(b) Waarbij de sub 52 vermelde naar Bengalen gezonden brief dd. 26 Juni 1819 in afschrift werd aangeboden, vergezeld van stukken. 
afschrift van een nader bij mij ontvangen brief van het Britsch opperbestuur in Bengalen, gedagteekend den $2 \mathrm{I}^{\mathrm{n}}$ Augustus jl. mede handelende over de zaken van Singapore.

Dezen brief en dien van den 26 Juni jl. zal ik eerstdaags beantwoorden; dan ofschoon de wederlegging van de daarbij voorkomende punten mij niet moeielijk toeschijnt en alhoewel de in paragraaf 4 vermelde omstandigheid boven allen twijfel tot klaarheid is gebracht, gelijk Uwer Excellentie uit de reeds overgezondene stukken bekend zal zijn, vrees ik echter dat, zonder eene beslissing uit Europa, geene verandering ten aanzien van Singapore te verwachten is. Die beslissing wordt daarom meer en meer noodzakelijk, en ik kan niet genoegzaam aandringen op eene spoedige regeling van dit belangrijke punt.

De laatste tijdingen van Banka zijn van den $26^{\text {n }}$ October en behelzen, dat de Palembangsche expeditie den $4^{\mathrm{n}}$ dier maand over de bank der rivier was gekomen; dat men tot den $\mathrm{IO}^{\mathrm{n}}$ of $\mathrm{II}^{\mathrm{n}}$ zich had bezig gehouden met het weder inschepen van geschut, hetwelk uit hoofde der weinige diepte op de bank was gelost, het verdeelen van de troepen op de kleine vaartuigen en andere noodzakelijke schikkingen, en dat omstreeks den $12^{\text {n }}$ de optocht was begonnen. Op den $26^{\text {n }}$ October had men nog hoegenaamd geene andere berichten te Banka ontvangen, dan dat de expeditie meer en meer Palembang naderde. De menigte van afgebrande vlotten, welke tegen de kust van Banka waren komen aanspoelen, deden vermoeden, dat men elk oogenblik beslissende en gunstige tijdingen kon tegemoet zien.

Bl. 426 noot 61. De brief dd. 16 December 1819 van onzen Landvoogd an het Opperbestuur luidde aldus:

Onder geleide van mijne secrete missives van den 24 September jl. $\mathrm{N}^{\circ} 7$ en 9 November jl. No 8, had ik de eer Uwe Excellentie aan te bieden afschriften van de brieven van het Bengaalsche opperbestuur, geschreven te Fort William op den $26^{\mathrm{n}}$ Juni en $2 \mathrm{I}^{\mathrm{n}}$ Augustus dezes jaars, dienende tot beantwoording van de mijne van den $25^{\mathrm{n}}$ Februari en $25^{\mathrm{n}}$ Maart te voren, betrekkelijk de bezitneming van Singapore door de Engelschen.

Uit die stukken zal Uwe Excellentie hebben ontwaard, dat het Britsche gouvernement beweert, dat de staten van Johor, Pahang, Rio en Linga geen onderhoorigheden van Malakka zijn, en dat wij geen recht hebben om ons tegen de occupatie van Singapore te verzetten; en dat hetzelve voorts van geyoelen is, dat de handelingen van de herstelde Nederlandsche 
regeering alle blijken dragen van een verlangen om zich ten nadeele der Britsche belangen uit te breiden en te versterken.

Hoewel ik mij weinig goeds voorspel van eene nieuwe wederlegging van deze onbewezen en ten deele ongerijmde stellingen, na al hetgeen ik reeds bij mijne brieven van den $25^{\mathrm{n}}$ Februari, $25^{\mathrm{n}}$ Maart en $13^{\mathrm{n}}$ April jl. over de daden der heeren Raffles en Farquhar heb gezegd, is het mij echter voorgekomen, dat $\S$ I 2 en volgende van den brief van 26 Juni eene geneigdheid om de onrechtmatigheid der occupatie van Singapore te erkennen, aan den dag legden, die wellicht door een nieuwen aandrang van onze zijde kan worden vermeerderd.

Ik oordeel daar te boven, dat de beschuldiging van heerschzuchtige en den Engelschen vijandige oogmerken te koesteren, niet onopgemerkt behoort te blijven, maar dat men veeleer moet trachten, lord Hastings door bondige redeneeringen en duidelijke bewijzen terug te brengen van een dwaling, waarin hij waarschijnlijk door verkeerde voorstellingen van de zijde van den heer Raffles is gebracht.

Deze gronden hebben mij genoopt om den brief van lord Hastings niet onbeantwoord te laten en aan Zijne Lordschap te schrijven de missive, die Uwe Excellencie kopylijk hiernevens gevoegd zal vinden, met alle de stukken, welke daarbij naar Bengalen zijn overgezonden, en welke, voor zooveel de Maleische stukken aangaat, op mijn last zijn verzameld, gedurende eene zending naar Rio en Linga, welke ik in de maand Maart jl. aan den kapitein Elout, een mijner adjudanten, opdroeg.

De brief aan lord Hastings bevat alles wat ik, zonder in herhalingen te vallen, van onze rechten heb vermeend te kunnen zeggen, terwijl dezelve ten aanzien van de in ons veronderstelde zucht, om door eene uitbreiding onzer macht den handel der Engelschen van dezen Archipel uit te sluiten, daadzaken inhoudt, die èn de ongegrondheid van dat vermoeden, èn de arglistigheid van dengenen, die hetzelve heeft doen ontstaan, op het duidelijkst aantoonen.

Ik verzoek mij kortheidshalve daaraan te mogen refereeren, mij vleiende, dat deze stukken, gevoegd bij die, welke ik de eer had vroeger af te zenden, Zijne Majesteit zullen in staat stellen, om in onze betrekkingen met de Engelschen in deze gewesten, die veranderingen te weeg te doen brengen, welke onze belangen, en onze eer niet minder op het dringendst vorderen.

De financieele berichten van Malakka zijn meer en meer 
ongunstig, en alles duidt aan, dat zoo Singapore in de handen der Engelschen blijft, dat Gouvernement een drukkend bezwaar voor de schatkist zal worden, zonder dat nadeel door een eenig naamwaardig staatkundig belang te vergoeden. $(a)$

Bl. 426 noot 62. Het schrijven dd. 8 Augustus 1820 van het East India House aan den Gouv.-Gen. van Bengalen luidde aldus (B):

I. Our last despatch was dated the $22^{\text {nd }}$ June.

2. In the present we shall confine ourselves to the affairs of the eastern islands and the relations with the Netherlands Government, on which subjects we addressed you on the $25^{\text {th }}$ January.

3. Since that period we have received two despatches from your Lordship in Council, dated on the $18^{\text {th }}$ December 1819 , the one referring to documents on the subject of the misssion to Acheen, and acknowledging the receipt of our despatch of the $22^{\text {nd }}$ May, the other continuing from your despatch of the $17^{\text {th }}$ July the correspondence with the Netherlands CommissionersGeneral and other papers connected with the affairs of the eastern islands. In each of these despatches you promise us a more detailed report upon the important matters to which they respectively refer; and we have expected with some anxiety both these reports, as well as the answer in detail to our despatch of the $22^{\text {nd }}$ May.

4. Upon the subject of Acheen we shall at present make no observations.

5. Upon that of the eastern islands, we have it now in our power to communicate to you the result of the discussions, so far as they have as yet proceeded, of which, in our despatch of January, we announced the expected commencement. (b)

6. We enclose copies of two notes which were exchanged on the $4^{\text {th }}$ instant between Lord Castlereagh and Mr. Canning as His Majesty's plenipotentiaries, and Baron Fagel and Mr. Elout, the plenipotentiaries of the king of the Netherlands, and of four articles provisionally agreed to, as proper to form part of the the treaty to be concluded $(c)$.

(a) Door dergelijke mededeelingen over den achteruitgang van Malakka ten gevolge van de inbezitneming van Singapore, kwam de minister Falck tot de jammerlijke overtuiging, dat als wij dit laatste niet konden terugkrijgen, het geheele schiereiland maar moest worden afgestaan; zie o. a. Falck's Brieven (1861), bl. 250 .

(b) Zie sub 56 .

(c) Zie Bijdragen E. bl. 139-144, 
7. You will observe that the conferences have been suspended principally on account of the difficulty of coming to a conclusion on the questions arising out of the occupation of Singapore, until we shall be in possession of your answer to the despatch from Baron Van der Capellen, communicated to His Majestys plenipotentiaries by those of the king of the Netherlands.

8. In the meantime your Lordship in Council will learn from the tenor of the notes and from the four provisional articles that the character of the discussions has been entirely amicable, and that the Netherlands plenipotentiaries have not only disclaimed, on the part of their Government, any design to establish a supremacy or an exclusive system of commerce in the eastern seas, but have engaged to stipulate in the intended treaty or convention, that no article tending to exclude British trade shall be introduced or allowed to remain in any treaty with a native power.

9. To illustrate the alleged moderation of the views of the Netherlands Government, Mr. Elout has appealed to the treaties which have already been concluded, and he has communicated to the British plenipotentiaries the treaties (of which we enclose translations) recently concluded or renewed with Sambas, Mempawa and Pontianak.

I0. It will appear that the Dutch have obtained in these places a footing of paramount influence, and the administration of the ports will be almost entirely in their hands. It is perhaps scarcely necessary for us to enjoin you to watch with vigilance, but without any unnecessary display of jealousy, the exercise of this power by the Netherlands authorities with the view of ascertaining whether, under the stipulation for the free resort of European traders, contained in the treaties with the native powers, British subjects really enjoy a facility of commercial intercourse, and are not subject to excessive charges or vexatious regulations.

I I. Mr. Elout repeatedly, in the course of the conferences, appealed to the British plenipotentiaries for some precise and attested cases in which the Netherlands authorites have acted, either towards British subjects, or towards those of any European power, in a spirit of injustice or oppression, or in which they have manilested any disposition to exclude from their own ports, or from those of the native powers with whom their connection has been renewed, the commerce of other nations. It seems almost equally impossible on the one 
hand that the strong impressions or representations which have been made, with reference to the oppressive conduct of the Dutch, can have been wholly groundless, or, on the other hand, that such a spirit as sir T. Raffles and the authors of certain publications in this country have imputed to the Netherlands government, can have existed without betraying itself in some overt acts. Yet none but general imputations have reached us.

I2. Mr. Elout has stated the three treaties above-mentioned, and one with Bandjermasin (of which he had no copy) to be all that had been concluded since the peace, with the exception of the treaty with the sultan of Djohor, of which we were previously apprised. The translation of the Djohor treaty, enclosed in sir T. Raffles' despatch to us of the $3^{\text {rd }}$ March 1819, was evidently erroneous. Mr. Elout has furnished extracts - in French - of the principal articles of that treaty, a copy of which extracts were likewise transmitted for your information.

13. In your Lordship's despatch to Baron Van der Capellen, you allege three grounds of resistance to the Dutch demand for the evacuation of Singapore, two of them affecting the question of evacuation simply, the third, the question «in whose favour the evacuation should be made?"

I4. If the subjection of Singapore to the sultan of Riouw shall be made manifest, and if the chief from which sir T. Raffles obtained the cession of that island shall appear not to be the true sultan of Djohor, you admit, nay, pledge the credit of the government, that our establishment upon that island shall be withdrawn.

15. But you add that the point in dispute is solely between you and the native sovereign of Djohor, unless it shall be shown that the empire of Djohor was itself a dependency of the Dutch Government; in which case, and in which case alone, the Netherlands authorities would have any right to demand, or to profit by, your relinquishment.

I6. Now the last point is one upon which the Baron Van der Capellen is altogether silent in his despatch of the $16^{\text {th }}$ December. It does appear to us, from that letter and from all the information which books or charts afford, that the ancient kingdom of Djohor included Singapore as well as Riouw; it does appear to us, also, that the person with whom sir T. Raffles treated as sultan was not the rightful sovereign of Djohor. But it would remain to be seen if the 
Dutch can make out their claim to re-enter into their former connections with Djohor, and to resume that species of controul or ascendancy in the councils of that state, which they unquestionably enjoyed in former periods.

17. The affirmation or denial of this proposition would rest upon the construction to be given to the proceedings of the Dutch authorities at Batavia and Malacca in 1795 .

I8. It is to be borne in mind that, if, as we have supposed, the two points, as to the extent of the Empire and as to the person of the sovereign of Djohor, were decided against us, the decision of the remaining point in our favour would not place us at Singapore, but would only bar the Dutch succession to us in that island. Now, we confess, we entertain considerable doubts whether that object be worth much contest. Much rather would we that the issue should have been our continuance by some compromise in a position represented to be so advantageous; - an issue which we should not have thought hopeless if the precipitancy of sir T. Raffles had not, in this, as in other instances, interposed every possible impediment to the success of amicable representation and pacific settlement, by mixing force with his remonstrances, and converting commercial rivalry into a national point of honour.

19. We have thought it right to enter thus far into an explanation of our opinion upon the litigated question as to Singapore and Riouw, in order that you may be perfectly apprised of the grounds on which the negotiators on the part of his Majesty have determined that it could not be at this period finally decided in England.

20. In the event of Singapore being abandoned, you will not fail to communicate to us your opinion, whether there be any other spot, either on Borneo or more to the eastward at which it might be expedient to form a British establishment, by way either of naval station or of depôt.

2I. In regard to Borneo we have to inform you that the arrogation of supremacy over the whole island, which has been imputed to the Dutch, has been distinctly disavowed by the Netherlands plenipotentiaries. If, indeed, the points which they have occupied are the only points worth occupying in that vast island (a question which we have not the means of determining) the disavowal of the Netherlands plenipotentiaries, it must be owned, is of no great practical value. It is valuable, however, as an admission of principle, 
and we are not informed on what ground their occupation of these points can be reasonably questioned.

22. In addition to the four articles upon which the Plenipotentiaries of the two crowns have agreed provisionally, two others were brought into discussion, of which we enclose copies. You will observe that, in one of these, a stipulation has been introduced against the abuse of the national flag:this stipulation was principally suggested by the transaction which occasioned the despatch of your Lordship in Council to Baron Van der Capellen of the $30^{\text {th }}$ October 1819 .

23. On the subject of the eastern islands, we shall only add that the approbation which we formerly expressed of your proceedings, in regard to the several acts of the LieutenantGovernor of Bencoolen, has been recorded on the face of the official note.

24. We shall now advert to some questions which have occurred with respect to the Dutch establishments on the continent of India (a). The Netherlands plenipotentiaries have, as was naturally to be expected, re-urged the several claims of their nation which were set forth in your political despatch to the Court of Directors of the $7^{\text {th }}$ February 1818 . It is not necessary for us to refer to what was said in answer to these claims; we advert to them in reference to a proposition which was been made for transferring to England, for a territorial or pecuniary consideration, all the Dutch establishments in India. The sentiments of your Lordship in Council upon the general desirableness of recovering the foreign settlements, are too well-known to us to require any explanation of the grounds upon which we feel anxious to see this proposition carried into effect; but we wish to direct your attention to it (as it is a matter which may not be brought to a conclusion before we hear from you in answer to this despatch) with a view to obtaining your opinion of the importance and value of each of these settlements respectively, and of the consideration which, whether in the shape of money, paid in a single payment or by way of annuity, or of an exchange of territorial possession, it may be prudent to give for the whole.

25. Although the period to which the conferences have been adjourned, is only until the arrival of the report of your Lordship in Council upon the Baron Van der Capellen's letter of the $16^{\text {th }}$ December, - yet as it is nevertheless possible that

(a) Ofschoon Malakka ook hiertoe zou gerekend kunnen worden, bedoelt men onder het vasle land van Indië steeds Vóór-Indië. 
circumstances may occur further to protract these discussions, we must anxiously impress upon your Lordship in Council the importance of keeping us informed from time to time and without delay of everything that may in any way affect the settlement of our relations with the Netherlands Government in the east.

Bl. 427 noot 63 . De beide belangrijke brieven te vinden op bl. 486 vv. van C. F. de Grovenstin's "Notice".

" 427 noot 64. Men zie dat korte antwoord dd. 22 April 1820 van Calcutta, in Bijdragen E. bl. 165-166. (Werd bovendien in B's verzameling opgenomen.)

" 428 noot 65. De brief dd. 17 Juni 1820 van het BritschIndisch Bestuur naar het Geheime Comitée der O.-I. C. te Londen luidde aldus (B):

We have the honour to transmit a continuation of our correspondence with the Netherlandish Government at Batavia, and other documents relating to the discussions pending between the two nations respecting their interests in the eastern seas, received and despatched since the date of our letter to your Honourable Committee of the $18^{\text {th }}$ December last.

2. We have also the honour to acknowledge the receipt by the "Asia" of your Honourable Committee's letter of the $25^{\text {th }}$ January.

3. The papers which we have from time to time submitted will convey to your Honourable Committee all the information in our possession as to the nature of the relations between Malacca, Riouw and Singapore. We now proceed to offer a concise statement of our present conceptions on this subject.

4. It appears that the Dutch East India Company was connected by treaties with the kingdom of Johore as late as I 787 and had a post at Riouw even at a later period, which post was dependent on Malacca.

5. It further appears that their force was withdrawn from Riouw before the establishment of our Government at Malacca, and on the occurence of the latter event the dependence of Johore and Riouw on Malacca was denied by the Dutch authorities.

6. In consequence, from that time to recent restoration of Malacca to the Netherlanders, no connection subsisted between Malacca and the principality of Johore. 
7. The Netherlanders now pretend that the connection formerly existing between Malacca and Johore was not affected by the withdrawal of their post from Riouw, or by the abnegation of their government at Malacca, and that it was revived by the retransfer to Malacca of their authority.

8. We, on the other hand, maintain that all the ancient relations had expired, the post, which was the essence of those relations, having been abandoned before the establishment of our government at Malacca, and the non-existence of our connection having been formally declared by the Dutch Government, which surrendered Malacca to us, and rights (had there been such) thus voluntarily relinquished both in profession and in act could not be revived, by the restitution of that residency, after a lapse of 23 years.

9. If our views of the question is correct, our right to a connection with the principality of Johore is prior to that of the Dutch, inasmuch as the treaty concluded by major Farquhar in 1818 preceded that entered into by the Netherlandish agents with the same authorities.

Io. If, on the contrary, the pretentions of the Dutch to the revival of their former treaties with Johore in consequence of the recovery of Malacca, notwithstanding their long disuse and recorded abnegation, be deemed just, their right to exclude us from Singapore, as resulting from their former treaties with the principality of Johore, might be of difficult disproval.

I I. In that case, the question would turn on facts of emancipation from the sovereignty of Johore, effected by certain of its dependencies, and on the validity of titles, in which discussion, notwithstanding the inherent equity of our plea, it would be hardly practicable to adduce proofs against the general presumption admitted for the Dutch.

I 2. For instance, a doubt of importance might occur, relative to the right of those chiefs to conclude treaties with us, with whom sir T. S. Raffles entered into engagements for the establishment of a post at Singapore.

13. It appears that the states of Riouw, Lingen, Pahang, and Johore, including Singapore, formerly constituted a kingdom under one sovereign. It seems that the nominal sovereignty, though dormant, still exists; but that latterly the power has been exercised separately and without much connection by the principal chiefs in their respective territories, such as the Raja Mooda of Riouw, the Bandahara of Pahang and the Tomongong of Johore. 
14. Whatever acts have been performed of late years in the name of the general sovereign have been by the Raja Mooda of Riouw; seemingly without the cognizance of the sovereign in whose name they have been done, and Riouw, though not the capital, nor the residence of the nominal sovereign, has for a long time back been the place of greatest consequence in the kingdom.

I5. The persons with, whom sir T. S. Raffles negotiated the treaty, concluded at Singapore, were the eldest son of the last sultan of Johore and the Tomongong of Johore, one of the chief officers of the collective kingdom, but apparently ruling Singapore with independent authority.

I6. The last sultan of Johore died about 8 years ago, leaving two sons. The eldest was not present at the time of his demise, and has not since been able to establish his succession to the throne of his father.

17. The Raja Mooda of Riouw appears to have been the most powerful of the chiefs of the state, and to have acknowledged nominally in his public acts the youngest son as his sovereign. The latter, however, appears to shun this dignity, and resides seemingly in retirement at Lingen. Though the Raja Mooda acted in his name at Riouw, he appears to have done so without any reference to Lingen. It is affirmed that the regalia of Johore, which are said to be essential to the acknowledged sovereignty, are still in the possesion of the widow of the late sultan, not having been yet conferred on either of his sons; from which circumstance it is argued that the succession is still unsettled $(a)$.

I8. Your Honourable Committee will observe very different statements on this question on the part of the Dutch authorities on one side, and sir T. S. Raffles and major Farquhar on the other.

19. The Government of Prince of Wales' Island, having had transactions with Riouw, has been in the habit of recognising as sultan the prince, whom the Raja Mooda of Riouw chose to acknowledge, and has expressed a decided opinion against the pretensions of the eldest prince, now at Singapore.

20. It is singular that though the Dutch have remonstrated

(a) In een nader artikel over Singapore's stichting zal ik al dergelijke beschouwingen, die uit Raffles' koker kwamen, voor zoover noodig, nog nagaan; nu reeds zij echter herinnerd, dat de Sultane, waarvan hier de reden is, geene kinderen uit haar huwelijk met sultan Mahmoed kreeg. Sultan Abdulrahman en Toekoelon waren kinderen van twee andere vrouwen. 
strongly against our establishing a post at Singapore and forming an alliance with the eldest of the princes, were not aware that the youngest prince has made any such remonstrance, or is in the least anxious to prevent the acknowledgment of his brothers sovereignty. In fact, the discussion is between the Netherlanders and ourselves, and the person who might be supposed the most interested seemed to be quite indifferent as to the issue.

$2 \mathrm{I}$. We confess that we require more perfect information before we can make up our minds on the question of the respective rights of the two princes; and are therefore glad that the termination of our discussions with the Netherlandish Government does not rest on this point.

22. We shall look with anxiety to the result of the negotiations, announced in your letter of the $25^{\text {th }}$ January, as about to be commenced by his Majesty's Government with the Commissioners appointed by the King of the Netherlands; and we trust that it will be such as to secure our rights and interests in the eastern seas and prevent any further collision with the Dutch authorities.

23. Your Honourable Committee will observe, in the despatches of the Lieutenant-Governor of Bencoolen, notice of further encroachments and demands of the Netherlands on the country of Indrapore and other places on Sumatra. With these exceptions we have not had any recent cause to complain of the conduct of their Government; and we are gratified by remarking a more moderate tone of late in their proceedings. Whether this change has proceeded from a sense of the justness of our opposition to their pretensions, or from the embarrassements in which they have involved themselves, we will not pretend to determine.

24. After expelling from Palambang the chief, whom we had established, and re-instating the one, whom we had deposed, the same, who had massacred the former Dutch factory, they fixed Mr. Muntinghe as their Commissioner at Palambang, whose proceedings gave so much disgust, as to excite the restored chief and the whole population against him. He was driven out of the Palambang territories with the military force, attached to him, and the standard of independance was unfurled. The Government of Java subsequently sent a formidable expedition to attack Palambang, but the assaillants were repulsed with heavy loss. They are now by the last accounts engaged in preparing another on a still larger scale. 
25. The Dutch have experienced revolt and contests in other parts of their recent acquisitions, and amongst others at Riouw. Some fugitives from the last-mentioned place having sought an asylum at Singapore, a demand was made by the Government of Malacca for their delivery, which was refused by the Resident. We entirely approve the conduct of the Resident in not complying with that demand; but enjoined him to be careful that those fugitives might not commit any offence against the Netherlands Government, whilst under the protection of the British flag.

26. Baron Van der Capellen in his letter of the $I 6^{\text {th }}$ December $18 \mathrm{I} 9$, received by us on the $2 \mathrm{I}^{\text {st }}$ April, has disavowed the pretentions set up by his agent at Pontianak to sovereingty over the whole of Borneo, and has offered a qualified explanation of their claims in that country, at the time of major Farquhar's mission. It is observable, however, that his Excellency sets forth the absolute necessity of extending the Netherlandish authority over Borneo and all the native states of the achipelago, and invites us to admit the existence of proofs of that necessity $(a)$.

27. We have declined a continuation of discussion on the several points of our controversy with his Excellency, expressing our confident expectation of the arrival of orders at no distant period from our respective governments for the settlement of all differences.

Bl. 428 noot 66. De dd. 26 Augustus 1819 door W. E. Phillips en W. A, Clubley onderteekende brief, luidt als volgt (B):

In obedience to your Excellency's commands, conveyed in Mr. secretary Melcalfe's letter of the twenty first of June, we respectfully beg leave to lay before your Right Honourable Board the grounds of the opinion which this Government communicated to the Honourable Court of Directors, in its dispatch of the eight of March last, declaring that there is one Sultan reigning over all the countries of Rhio, Lingen, Johore etc.

2. The person with whom sir Stamford Raffles formed the late treaty at Singapore, had never to the knowledge of this

(a) Een staaltje hoe lord Moira ten slotte ook door dubbelhartigheid ons bestuur trachtte verdacht te maken. Van der Cappellen had de noodzakelijkheid . aangetoond, dat eenige Europeesche mogendheid zich de bestrijding van den zeeroof aantrok: wat was daarin observable?

6e Volgr. V. 
Government been recognized as a Sultan by any European or native government. Possessing but the most slender intellect, he had been always content to live under the controul of his uncle the Raja Mooda of Rhio; nor, until produced by sir Stamford Raffles, had he ever been known to this Government to advance any pretensions to the Musnud of Johore.

3. His younger brother however, the person reigning for the last fifteen years at Lingen had always been styled after their father, and acknowledged in the correspondence of this Government Sultan of Johore, as well as of Rhio and Lingen, and had moreover an officer under his authority, denominated Tomagong or Governor of Johore, who was a party to the late Dutch treaty.

4. But our principal sources of information on this point had been furnished by sir Stamford Raffles and major Farquhar themselves.

5. The former gentleman in a public document, recorded in the twelfth volume of the Asiatic Researches expressly states in page one hundred and fifteen, that the seat of Government has long been transferred from Johore to Rhio and Lingen; whilst major Farquhar in the Commercial treaty he concluded last year with the Rajah Mudah of Rhio recognized the Sultan residing at Lingen in the very preamble to that treaty as King of Johore, and that this was not a mere empty title assumed by the Sultan of Lingen, is proved by the circumstance of his minister of Rhio, stipulating in the second article of that Treaty, to confer on us the same privileges in the ports and dominions of Johore as in those of Rhio and Lingen. It was through major Farquhar that the communications of this Government with the Malay states below Malacca had generally been conducted and it may be fairly presumed that at the time he signed that commercial treaty, he fully believed the minister at Rhio was not assuming a jurisdiction over the ports and dominations of Johore to which the Sultan at Lingen had no right or title: we beg to enclose a copy of that treaty and also a copy of the letter from the Chief authority at Lingen to major Farquhar.

6. It will of course now rest with sir Stamford Raffles to prove to your Excellency in Council whether any of the Malay states in the neighbourhood of Johore, ever recognized or even now acknowledge the person at Singapore as the Sultan 
of Johore, or as an independant chief; we can only repeat to your Excellency our assurance that this Government never did.

7. With respect to the opinion that the establishment of a British post at Singapore cannot be supported by reason or justice, we entreat your Excellency will observe that this was a conclusion drawn from certain premises, on the truth and correctness only of which and particularly of the opinion before explained, it can be entitled to attention. We solicit permission however to declare the peculiar circumstances under which this Government presumed to record that conclusion. A vessel was proceeding direct to Europe from this Presidency, by which opportunity it was currently spoken sir Stamford Raffles was addressing voluminous dispatches to the Honourable Court of Directors, respecting his proceedings at Singapore. Our late President $(a)$ being at that time most confident and most positive that those proceedings would be entirely disavowed by the Supreme Government, and the tenour of two dispatches dated twelfth and twenty sixth December, then just received from Mr. secretary Adam appearing to confirm this conviction, he conceived it the bounden duty of this Government to prevent sir Stamford Raffles's dispatches from anticipating the judgment of the Honourable Court by representing to them, by the same opportunity, that a wide difference prevailed on the subject between that gentleman and the Government situated nearest the scene of his proceedings.

8. We feel much distress and concern to find that your Excellency considers some of the expressions in that dispatch indecorous and unsuitable, and this distress our late lamented President would have experienced most severely, for we can assure your Lordship, that the draft of that dispatch was more than twice revised by colonel Bannerman himself with the sole view of preventing any expression of his from appearing exceptionable to the Supreme Government.

Bij missive, gedagteekend Fort William 2 October 1819 van den gouvernementssecretaris Metcalfe werd bovenstaand schrijven in handen gesteld van Raffles, die destijds weder te Calcutta was, "in order that you may have an apportunity of explaining the grounds of the different views which you have taken on the same subject". Raffles vol-

(a) Namelijk Bannerman. 
deed hieraan bij ondervolgende missive, gedagteekend Caleutta 6 Januari 1820 (B):

I have the honour to acknowledge the receipt of your letter of the $2^{\text {nd }}$ October, transmitting a copy of a letter from the Government of Prince of Wales' Island in order to afford me an opportunity of explaining the grounds of the different views we have taken of the same subject, and in reply beg to submit the following observations.

2. The arguments there advanced appear to be but an echo of those employed by the Dutch authorities, and the statements I have already had the honour to make to his Excellency in Council will have shewn the grounds on which I considered them inaccurate. $(a)$

3. I have already in my reply to the representation of the Netherlands authorities had occasion to meet the statements contained in the $2^{\text {nd }}$ paragraph of this letter, «that the Prince with whom I formed the late treaty at Singapore had always lived under the control of his uncle the Rajah Mooda of Rhio and had not been known to advance any pretensions to the Musnud of Johore». I have stated that the Prince in question is the eldest son of the late Sultan of Johore, and that he was intended by his father for the succession; the circumstances which kept him out of his power and rights, and induced him for the time to be content with a share of the revenues of Rhio, are fully before His Lordship in Council. It will be sufficient here for me to repeat that the agreement subsisting between the Malay chiefs of Johore for the division of the revenues of Rhio, in no way affected the independance of this Prince, and that although his peculiar circumstances made it necessary to his interests to make Rhio his principal residence, that residence was perfectly optional. In my letter from Penang of the $16^{\text {th }}$ January to Mr. secretary Adam I informed His Excellency of the circumstances under which this Prince was placed on the information I received from the native and other traders at that place. Why these circumstances, so well known to all who had any acquintance with the affairs of that quarter, should be unknown to the Government of Penang, it is not for me to explain.

4. The statement that the Prince, with whom the treaty of Singapore has been made, is possessed of the most slender

(a) De hier bedoelde brieven zal ik in een volgend Singapore-artikel publiceeren. 
intellect, is, I am inclined to think, founded on a mistake of the persons as this is the opinion generally entertained of the second son, the Rajah of Lingen, and assigned as the reason why the Rajah Mooda has employed his name in opposition to the substantial rights of the elder, against whom I am not aware that such a charge has been made. $(a)$

5. In the $3^{\text {rd }}$ paragraph where it is stated that the person reigning for the last fifteen years at Lingen had always been styled after their father, and acknowledged in the correspondence of this Government as Sultan of Johore as well as of Rhio and Lingen», there appears to be some mistake, as Sultan Mohamed died not more than seven or eight years ago. $(b)$

6. The quotation from the $12^{\text {th }}$ volume of the Asiatic Researches in paragraph $5^{\text {th }}$ is perfectly correct. Old Johore has been abandoned for nearly a century, and the last Sovereign, Sultan Mohamed resided alternately at Rhio and Lingen. I cannot but regret that the Government of Penang, professing to derive their information on this subject from me and major Farquhar, should hare preferred ransacking the archives of a literary society to availing themselves of the fuller and more recent information with which I was ready to furnish them. (c)

7. On the $6^{\text {th }}$ paragraph referring to me sto prove whether any of the Malay States in the neighbourhood of Johore ever recognized or even now acknowledge the person at Singapore as Sultan of Johore, or as an independant Chief", I need only remark that the facts of the case are already fully before His Excellency in Council, that it is almost unnecessary to repeat them here The states of Johore consisted of three independent chiefs, who had the right of investing and installing the new Sultan. These are the Bandahara of Pahang, the Toomongong of Singapore, and a third now extinct. Each of these exercised a perfectly independent authority within their respective jurisdictions. The Rajah Mooda was entrusted with the controul of the Bugguese and the port of Rhio, but by his birth was excluded from any

(a) Wij zullen in ons volgend Singapore-artikel zien dat schout-bij-nacht Wolterbeek geenszins sultan Abdoerahman zoo laag schatte. De Sultan stond bekend voor een "doorslepen vos". Ook het sub 8 vermelde rapport van Farquhar zelf geeft over den sultan niet een ongunstig oordeel.

(b) Geheel en al Raffles. 't Bedoelt natuurlijk eene insinuatie over de onwaarde van het gansche stuk.

(c) !! 
voice in the election and from any controul over the Malay population. On the demise of the late Sultan, the eldest son and intended successor was absent at Pahang, and on arcount of the adverse moonsoon was unable to return till many months had elapsed, and when he did, found so many obstacles thrown in the way of his regular succession and so many pretexts started for delay, that from want of means he had never been able to obtain his rights. His claim however is now at any rate openly acknowledged by the Toomongong of Johore, one of the two chiefs who have by the custom of the Empire a voice in the election. I may also observe in reference to the acknowledgement of his rank and independence that in letters to this address from the Bandahara of Pahang and the Tuanko Putri, widow of the late Sultan, who still retains possession of the regalia, he is styled Yang di pertuan Sultan Hussein Mahomed Shah, the tittle by which we recognize him. To this it may be added that I am aware that the Rajah of Lingen had been styled Sultan of Johore by any other native authority than the Rajah Mooda of Rhio who has constitutionallly no voice on the occasion.

8. Major Farquhar was not ignorant of the circumstances of the Prince whose cause we have espoused; he had while resident of Malacca received communications from him, and had I believe been in correspondence with him, but he could lament his misfortunes $(a)$. When he was directed to conclude treaties with the States of Rhio and Lingen, he must naturally have inferred from the statements of the Prince and the part taken by the Rajah Mooda of Rhio in favor of the Rajah of Lingen that the fortunes of the former were hopeless and that the latter was actually invested with the authority and title of Sultan of Johore. On proceeding to Lingen however in order to obtain the authority of that chief as Sultan of Johore to the treaty he wished to conclude, it appears the latter expressly declared to him that he was not Sultan of Johore, and desired that he might not be addressed by that title and if a corroboration of the fact were wanting it will I conceive be found in the very letter alluded to in the $5^{\text {th }}$ paragraph of the letter from the Government of Prince of Wales' Island, wherein he expressly states that he «had never from the first to the present time been in the habit of discussing any State affairs, and that no matters of business

(a) Wat een medelijden! De hier bedoelde correspondentie geef ik in een volgend Singapore-artikel weder. 
had ever yet appertained to him". It is to be remarked that major Farquhar's visit to him was solely on account of his supposed rank, that he expressly addressed his communication to him as Sultan of Johore, but that the reply above alluded to is stated even in the letter from the Government of Penang to be from the "Chief Authority at Lingen" only, and I refer to that document to know what titles he there assumes and whether the seal affixed to it is that of Sultan of Johore or simply of Lingen, I apprehend it will be found to be the latter. Major Farquhar then went to the Rajah Mooda of Rhio with whom he entered into the treaty. It is true that in this treaty reference is made to the authority of the Chief at Lingen as Sultan ot Johore, it was indispensable that the Rajah Mooda should acknowledge some superior, and it suited his interests to allude to this one, but it was impossible after what had passed between the Rajah of Lingen and major Farquhar that an attempt could be made to have it ratified by that chief; accordingly no such attempt was made $(a)$. The treaty was thus left incomplete, and the question in as far as concerned the Sultan of Johore still remained in doubt, but did not appear at the time an object worthy of investigation $(b)$.

9. It is unnecessary to enter into the circumstances of the Dutch treaty further than to observe in explanation of the Tomongoong having been a party to it, that the particulars of this transaction as related by the Tomongoong himself are already before his Lordship in Council in my letter of the $I 7^{\text {th }}$ January 1819 . However weak the conduct of the Tomongoong may have been influenced by an overdesire to shew. his independence of the Dutch treaty, it is evident that in affixing his seal to it, he did so from fear and necessity alone. $\mathrm{He}$ was induced to go to Rhio at the urgent request of the Prince to whose cause he was attached, and with a view of opposing and protesting against any treaty with the Dutch authorites $(c)$. He naturally expected to be able to act according to his judgement but the overpowering

(a) Als geen poging werd aangewend, kon de onmogelijkheid ook niet zijn gebleken. Men leze het sub 8 wedergegeven verslag, waarin geen twijfel hoegenaamd over de waarde van het contract wordt uitgedrukt.

(b) Raffles betoogt dus de waardeloosheid van Farquhar's contract. Lord Moira daarentegen oordeelde dat dit verdrag boven Wolterbeek's contract moest gesteld worden: zoo loog men tegen elkaar op!

(c) Neen; sultan Abdoerahman zelf had hem bij de komst van Wolterbeek door den kroonprins laten halen! 
force of the Dutch compelled him when once there, to put his seal to the document on his being assured that the treaty in no way affected his own States or authorized the interference of the Dutch in them. He considered this treaty as only affecting Rhio, and immediately returned to the seat of his own independent government at Singapore.

Io. When I found that the Dutch had thus superseded us at Rhio, it was evident I could not interfere at that port without a direct collision with the Dutch authorities, but when I obtained from the Tomongoong at Singapore a confirmation of all the circustances which I had heard respecting the legitimate successor to the throne, and further learnt from undoubted authority that no installation had taken place since the death of Sulthan Mohamed, that the regalia were still in possession of his widow, and that the succession might be considered in dispute, it occured to me that as the Tomongoong supported and acknowledged the Prince who appeared to me to have the legitimate title, our object might be obtained within his dominions by our acknowledging that Prince, who it appeared had in no way committed himself to the Dutch authorities, and was at liberty to treat with us or any other power which might be inclined to enter into alliance with him.

12. Under this view I should hope there will not appear any foundation for the opinion «that the establishment of a British post at Singapore cannot be supported by reason or justice", and that the Government of Prince of Wales' Island itself will be inclined on further consideration and fuller information to alter the opinion it first expressed. As a palliation of the apparent haste with which the conclusion was recorded, it is further stated that «a vessel was proceeding to Europe from that Presidency, by which opportunity it was currently spoken, I was addressing voluminous dispatches to the Honourable the Court of Directors, respecting my proceedings at Singapore". I have to regret that a degree of jealousy which I shall not pretend to account for, must have led the Government of Prince of Wales' Island to listen to and act upon idle rumours when it had it in its power to ascertain the fact by a direct application, when I would have had in my power to set at rest the apprehensions of my «anticipating the judgement of the Honourable Court", and of informing them that I was not sending home voluminous dispatches, or anything further than the copy of 
my first letter to the Supreme Government announcing the occupation of the post.

Bl. 429 noot 67. Stuart's minuut, gedagteekend Fort William, 22 Juni 1820 , luidde als volgt (B):

I beg permission to submit some observations to the Board as a sort of supplement to the proposed draft of a letter under this date to the Honourable the Secret Committee upon the discussions pending between this Government and the Goverment of Java, relative to the interests of the two nations in the Eastern seas.

It is obviously of importance that the authorities in England should be in full possession of all that constitutes the strength and weakness of our antagonists' claims, and upon that consideration, there is a view of their case with reference to Singapoor, which appears to merit attention.

The Netherlandish Government maintain their right to a supremacy over the state of Johor, in virtue of treaties which existed anterior to the British occupation of their possessions. That pretension seems, to say the least, to be very questionable. But we must recollect that the Netherlandish Government can also urge a recent treaty with Johor, by which that state has recognised and submitted to their supremacy. It must be admitted certainly that the treaty is not valid to establish against us the alleged existence of the Dutch supremacy down to the period at which that treaty was executed. But I presume that, from the date of the new treaty, the Netherlandish government are entitled to oppose their supremacy over Johor against us, and to dispute our occupation of Singapoor upon that ground, as an infringement of that supremacy, if in fact it be so. The new treaty with Johor, if not good against third parties, as a recognition of a subsistence of the old supremacy, yet is, by fair implication, a new engagement for the future dependencies of Johor upon the Netherlandish government valid against all the world.

It is true that our treaty with Rhio preceded the recent treaty of the Netherlandish government, and supposing the ancient ties between that Government and Johor to have been dissolved, we seem entitled to contend that the right acquired by us under our treaty shall not be affected by the subsequent treaty procured by the Netherlandish government. But all that we stipulated for in our treaty was to be placed in commercial privileges upon a footing with the most favoured nation. That we shall not be deprived of the benefit of that 
stipilation, we seem entitled to claim; but I do not perceive how we can make use of our treaty to justify the occupation of Singapoor. $(a)$

How far Singapoor may be dependent upon Lingin and Rhio, and be therefore included in the Netherlandish treaty, is a separate question: but it must be confessed that the act of the Toomengoong in attending the execution of that treaty and placing his seal to it, combined with the Toomengoong's letters to the Prince at Lingin, from which the GovernorGeneral of Java submitted extracts, with his letters of the $16^{\text {th }}$ December 1819 , give a strong color of probability to the assertion of the Netherlandish authorities, that Singapoor is still a dependency of the state of Johor.

If the independence of Singapoor could be assumed, then of course the Netherlandish authorities could have no right to question our occupation of it by the consent of its independent ruler. If its dependence on the state of Johor be admitted, then we can only defend our possession by proving the rightful title of the Prince Tunkulong, under whose grant we hold it, as sovereign of the state of Johor.

Acknowledging the uncertainty of this question of the respective rights of the two Princes, the draft expresses satisfaction that the termination of the discussions between the two Governments does not rest on that point. (b)

That is a part of the subject on which I have experienced great difficulty. The case of Singapoor excepted, I do not perceive that any questions exist between the two Governments which afford matter for negotiation.

The Dutch have returned to the eastern archipelago with all the rights and faculties of an independent nation. They are free to pursue their plans of policy, to assert their ancient treaties, to form new ones. They must be expected, as all nations will do, to seize favourable opportunities for extending and strengthening their empire. In pursuing their interests and the prosperity of their state, they are bound certainly to respect the laws of nations, the principles of justice, and the ties of treaties. We possess the same rights, subject to the same obligations. I presume, for instance, that

(a) Stuart komt hier op het hart der quaestie: het tractaat van Farquhar hield geene verklaring van onderworpenheid aan het Engelsch gezag in.

(b) Uit deze aanhaling blijkt duidelijk, dat Stuart op het oog heeft den Calcuttaschen brief van 17 Juni 1820 (sub 65, zie $\$ 21$ ), die hij in den aanhef van de minuut noemt proposed. Hieruit volgt, dat mijne voorstelling op bl. $428-429$, volgens welke Stuart slechts op den brief heeft nagepleit, niet eens juist is! 
as far as the Dutch are concerned, we are entitled to push our commerce, to form alliances, to occupy territory in every part of the eastern seas over which they do not exercise sway. If, in the mutual pursuit of our interests, conflicts should arise, as one has arisen relative to Singapoor, each case must be decided on its own merits, and with reference to the obligations which I have stated; but I am not aware by what general abstract explanations or definitions of the respective rights of the two nations we could be secured against collision.

My observation wil not indeed apply to conventions between the two nations for restricting their respective establishments within assigned limits, or for abstaining reciprocally from occupying certain positions. Such arrangements may', of course, form a subject for negotiation, and if adopted might be useful in preventing collision. Specific plans have accordingly been suggested. But I fear that the difficulty of devising arrangements of this nature, which both parties will deem equal, opposes an almost insurmountable obstacle to their adoption. There is one not perhaps quite hopeless, and which appears highly desirable. It is simply that we shall withdraw from Singapoor and the Java Government abandon Rhio. The mutual concession would save the point of honour on both sides: we should remove the Dutch from a naval station likely to prove very injurious to our valuable China commerce in time of war: they would be relieved from a galling rival establishment upon the skirts of their chief settlements. All parties might find their account in such an adjustment.

Throughout these discussions one reflection has always been present to my mind, the justness of which I submit to the Board and the authorities in England.

By the convention of 1814 , we have not only restored the Dutch to the actual supremacy over the best and fairest parts of the Eastern archipelago. We have also placed in their hands means so powerful of completing their dominion over those regions, that if the Nation retain her original possessions, she can only fail in that object by the most signal deficiency of wisdom and of conduct. I might proceed further and show that a powerful European nation, seated in the midst of semi-barbarous turbulent and anarchical Asiatic states, would be gradually constrained, in despite even of her own choice, if her choice should be contrary, to reduce them universally under her sway. We must then, as to a 
considerable extent we do already, hold our commerce in those regions upon the terms which the policy of the Netherlandish nation may impose, just as she holds at our discretion her commerce on the seas and upon the shores of Hindostan. By immediately commencing an active competition with that Goverment in quarters over which she has not yet extended her domination, we might perhaps secure some share of influence and power in the Eastern archipelago; but without at all undervaluing the eastern trade, it appears to my humble judgment to merit great consideration, whether the object, if attainable would require the expense, contention and national animosity that must be encountered in the pursuit.

Bl. 429 noot 68 . Woorden van baron Brunnoff, die door keizer Nicolaas naar Londen was gezonden, om daar de ongerustheid weg te nemen, ontstaan door den veldtocht tegen Khiva. Zie Wetenschappelijke Blarlen, Februari 1898 blz. 247 : "Koningin Victoria en keizer Nicolaas I", een belangwekkend artikel uit de Revue Suisse van Michel Delines.

Bl. 430 noot 69 . Ten einde de hoofdzaak niet te zeer uit het oog te verliezen, kan ik over de hier bedoelde belangrijke stukken niet uitweiden. Men vindt echter Clancarty's nota dd. $2 \not$ Augustus 1819 en ons antwoord den $31^{\mathrm{n}}$ d.a. v. bij Van Deventer op bl. 282 en 286.

" 431 noot 70. Zie art. 8 der Instructie op bl. 86 Bijdragen E. Al wat ik verder mededeel heb ik mede aan die Bijdragen ontleend, zoodat ik de bladzijden niet nader aanwijs.

" 440 noot 71. Ik heb mij afgevraagd of de dagteekening van den brief, die in B's verzameling vermeld staat, namelijk 26 Januari 1822 , eene schrijffout is, zoodat hier het jaartal 1821 bedoeld zou zijn. Er komen toch weleens verschrijvingen voor. I $k$ denk dit echter niet, daar driemaal in het stuk (boven en beneden) diezelfde datum gesteld werd.

" 44.1 noot 72. Ik heb hiermede speciaal op het oog den ondervolgenden brief van Directeuren der O. I. C. dd. 13 Maart 1823 aan Bengalen. Daar het over verscheidene onderwerpen handelende stuk toch ook bij latere gelegenheid 
te pas komt, is er geen bezwaar tegen om het nu reeds in zijn geheel over te nemen (B):

In this despatch we shall advert to the state of our relations with the European powers in India.

The negociations with the Netherland Government have not been renewed since the signature of the provisional articles which were communicated to you by our despatch of the $8^{\text {th }}$ of August, 1820 . If any application should be made to you on any of the disputed points by the Dutch authorities you will inform them that the whole matter is under the consideration of His Majesty's Government in England, but that you are, nevertheless, ready to convey to the Government any representation which the Dutch may think proper to make to you.

Our motive in desiring you, so far, to encourage a communication from the Dutch rather than to refer them entirely to their own Government in Europe, is the desire that any such representation may be received here, together with your comments, and particularly with your statement of the facts to which it may refer. We trust that the non-arrival of any plaint from the Bengal Government of the conduct of the Netherlanders in the Eastern Seas may be taken as an assurance that none of those unfriendly proceedings have occurred, or unjustifiable pretensions been advanced within the last two years, which were accidently the subject of representation, not only from the Lieutenant-Governor of Bencoolen, but from Lord Hastings in Council $(a)$; and that the officers and traders of that nation have conducted themselves in the spirit manifested by Baron Fagel and Mr. Elout in their official note of the $4^{\text {th }}$ August, I820 (b). You will inform us whether this confidence on our part is well founded. The letter from Bengal, $I^{\text {st }}$ March, I82I., in answer to our despatch of the $8^{\text {th }}$ August, $1820(c)$, certainly did not give a very flattering impression of the intentions of the Dutch, but as the lapse of time, and the result of the late negotiation may have produced an alteration, we wish you to resume the consideration of our letter of August, 1820 , and again to answer it.

In the Calcutta Journal for the month of September, I822, we have perused a paper, purporting to a Proclamation by

(a) Hastings (lord Moira) was als gouverneur-generaal afgetreden.

(b) Opgenomen in Bijdragen E. bl. 141.

(c) Zie sub 62 . Het bedoelde antwoord van 1 Maart 1821 haalde ik o. a. aan in sub 130 Opvattingen; t. z. t. zal ik den geheelen brief publiceeren. 
Baron Van der Capellen, dated Batavia, $9^{\text {th }}$ July, I822 (a). We wish to have your opinion of the origin and effect of this Ordinance with reference to general facilities of trade and to its compatability with the additional, unsigned article respecting duties which accompanied our despatch, $8^{\text {th }}$ August, I820. As to export, it would appear to subject foreign vessels to double duties, which is conformable to the intention of the Plenipotentiaries.

You will continue to occupy Singapore, and to report to us the progress of that Settlement in population and commerce. You will apprise us whether there has been any communication on the part of the Sultan of Johore, or any other native chief to deny the validity of our title to the Island; any such pretension coming directly from the native prince you will receive with attention, and fairly investigate, but you will not receive any such claim which shall come through the channel of the Netherland authorities, nor from a native who shall be under their control.

These are all the instructions which we can now give you as to the East Indian Islands. We anxiously expect a report of the further proceedings of $\mathrm{M}^{\mathrm{r}}$. Crawford. Our latest information is contained in the political letter of the $26^{\text {th }}$ January, 1822.

We shall now advert to the Continental Settlements. Your despatches of the $30^{\text {th }}$ June, I8I 7 , and the $I^{\text {st }} \mathrm{July}, \mathrm{I} 82 \mathrm{I}$, with one from Madras on the $27^{\text {th }}$ October, 1817 , convey to us the latest information which we have received to enable us to judge of the value of the several settlements and factories of the Dutch, and other European nations on the Continent of India, and of the expediency of entering upon a negotiation for the purchase of these possessions, and all dependent priveleges and immunities. You will resume the consideration of this subject, especially as to the possessions of the Dutch.

In regard to the several pretensions of the Netherlanders, set forth in the political despatch from the Governor General in Council of the $17^{\text {th }}$. Feb., 1818 , or subsequent letters, you will state them to be still under the consideration of the two Governments in Europe, and you will, in like manner, refer to Europe any new questions which may arise.

In cases such as that of the Pearl and Chonk Fishery, (which has been specially brought to our notice by the Go-

(a) Eene verordening op de in- en uitvoerrechten; ik maakte er melding van op bl. 237 van mijne jongste verhandeling over "Sumatra's Westkust" (ov. bl. 33) 
tion in an existing revenue, you will cause a correct account to be kept, in order to facilitate the future adjustment between the two nations, and you will, so far as it may be practicable, adopt, in regard to all disputed points, a corresponding principle, so that the Dutch may receive as little injury as possible from the delay which may take place in deciding upon the admissibility of their claims.

The arrangement made with the French and Dutch respecting salt will remain undisturbed, unless you shall see occasion for an alteration.

With respect, however, to those pretensions which we have formerly instructed you to resist, you will continue to hold the same language as heretofore, and will give no reason to expect any alteration. Such are all claims to exemptions from duties, or other immunities founded upon the ancient grants of native princes, or upon any other basis than the Convention of the I $3^{\text {th }}$ August, 1814 , relative to the several Dutch $\gg$ Establishments which are situated within the limits of the British sovereignty in India».

These injunctions to refer to Europe all questions affecting foreign settlements, but to reassert, nevertheless, the prinvernment of Madras) in which the Dutch claim a participaciples which you have been directed to maintain, are applicable to all other European powers.

But as certain pretentions have been lately urged upon the Danish Minister at this Court on behalf of the factory of Serampore, which are more extensive in their effect, and more objectionable in their origin than those which have been made by the Danish authorities in India, we think it right to apprise you of these pretentions, and of the opinion regarding them which has been conveyed to the Danish Minister by his Majesty's Secretary of State for Foreign Affairs, and to enclose for your information copies of the notes which passed on this occasion.

Erratum. Suh 2 staat, dat mijn artikel over „Mr. C. T. Elout als CommissarisGeneraal in Nederlandsch-Indië" voorkomt in De Tijdspiegel van Juni 1898: dit moet zijn Juli 1898. 